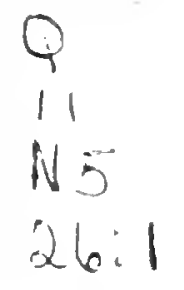

ANNALS OF THE NEW YORK ACADEMY OF SCIENCES Vol. XXV'I, pp. 1-70, pll. I-III

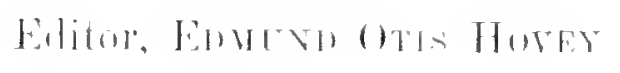

\title{
GEOLOGICAL RECONNOISSANCE OF PORTO RICO
}

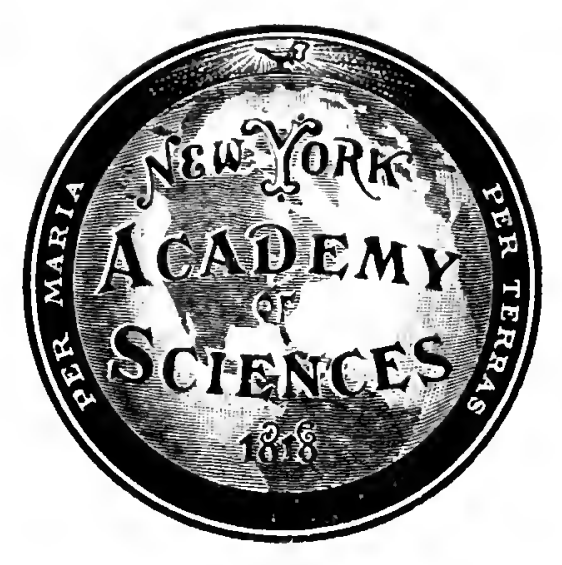

NEW YORK

PUBLISHED BY THE ACADFMY

3 MARUH, 1915 


\section{THE NEW YORK ACADEMY OF SCIENCES}

(Lyceum of Natural Histori, 1817-18\%6)

(1) WUER, 1915

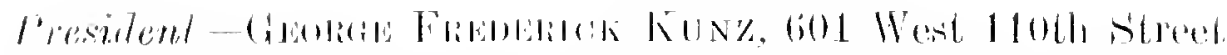

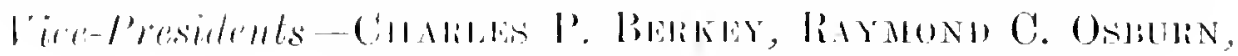

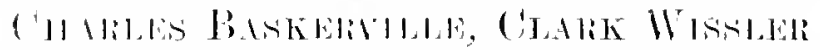

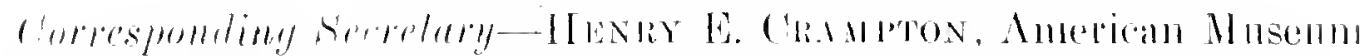

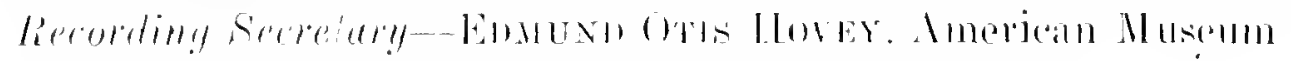

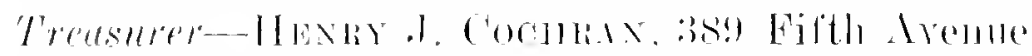

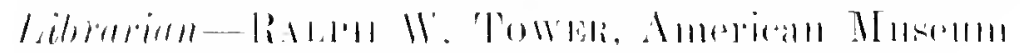

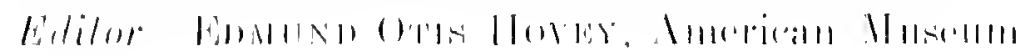

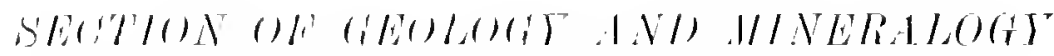

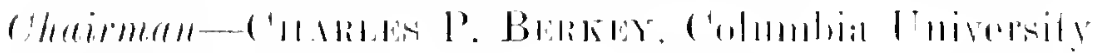

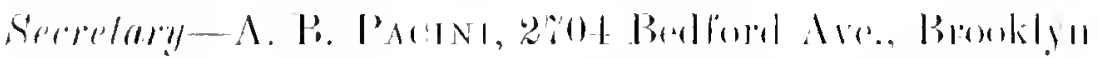

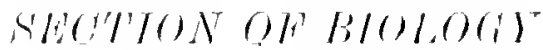

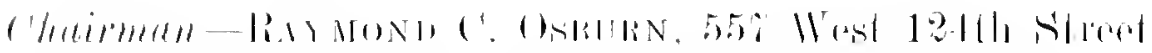

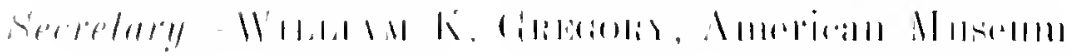

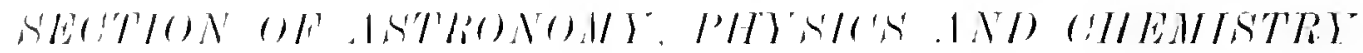

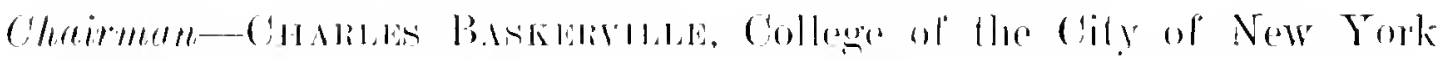

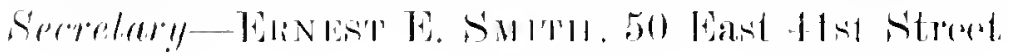

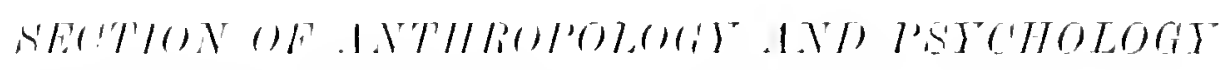

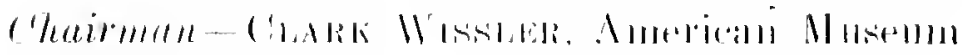
Serretury-lioblate H. Low A. Antrican Museum

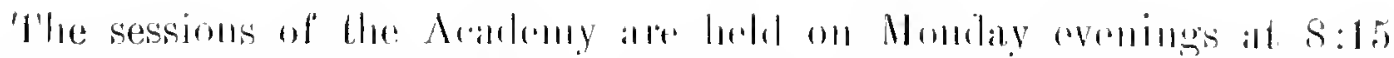

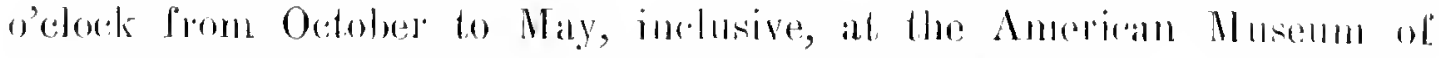
Natural Ilistory, rath strend and central Park, West. 


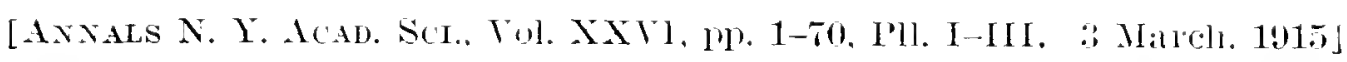

\title{
GEOLOGICAL RECONNOISSANCE OF PORTO RICO ${ }^{1}$
}

\author{
By Chantes P. Beirey
}

(1'resented in abstract before the Academy. : December. 1914)

(ONTENTS

\section{Introduction}

General descriptim

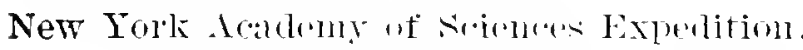

Object of the axjerlition.

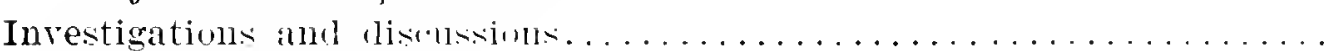

Rock formations .........................

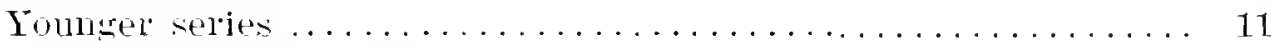

sim .Juan formation . . . . . . . . . . . . . . . . . 11

Arecilo formation . . . . . . . . . . . . . . . . . . 12

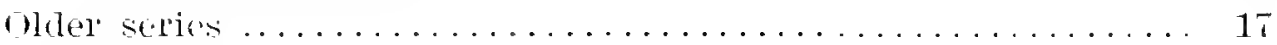

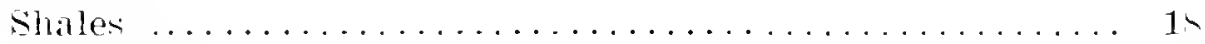

Limbetunes . . . . . . . . . . . . . . . . . . . . . . .

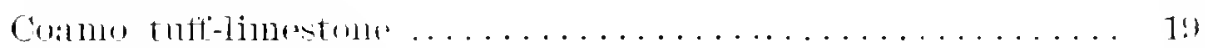

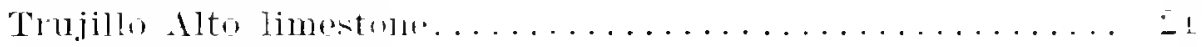

"shrerl" linestone ........................

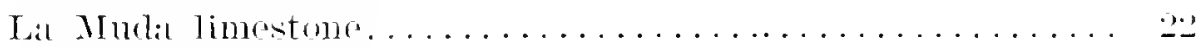

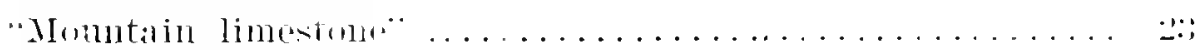

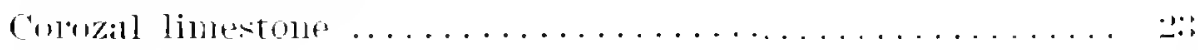

(m)

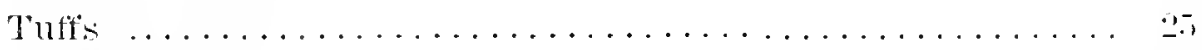

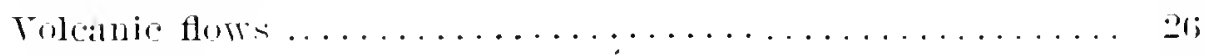

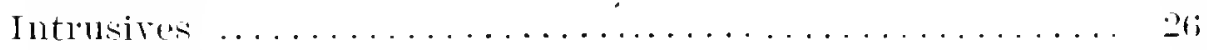

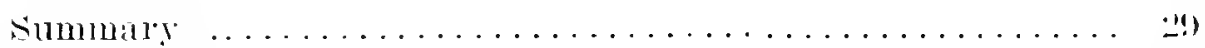

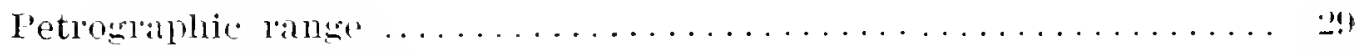

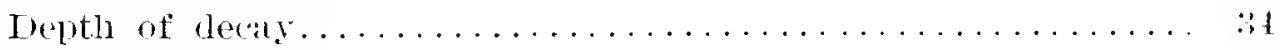

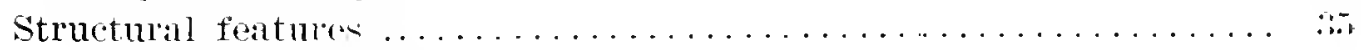

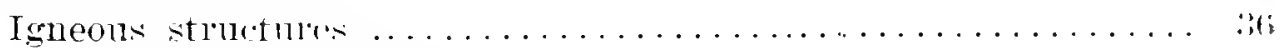

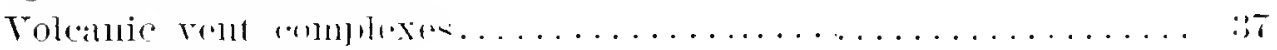

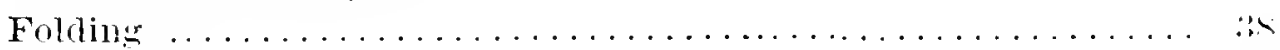

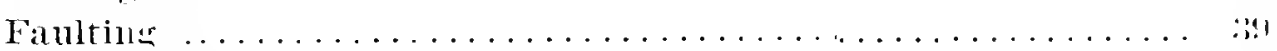

Lal

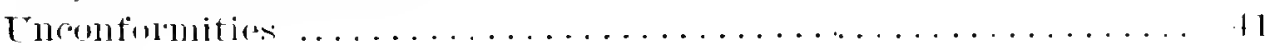

Veins $\ldots \ldots \ldots \ldots \ldots \ldots \ldots \ldots \ldots \ldots \ldots \ldots \ldots \ldots \ldots \ldots$

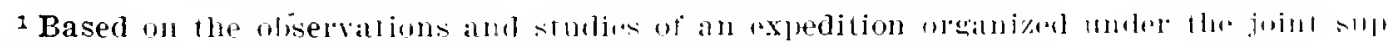

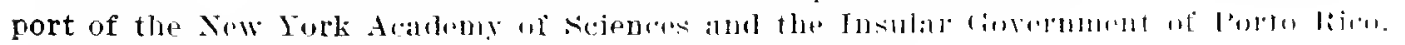

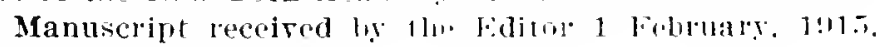


. l'age

Millor structures .......................... 43

Futerolithic stunctures .................... 43

Double cross-bedding ...................... 43

Sperial relief features......................... 47

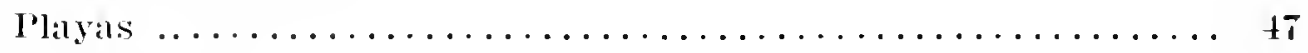

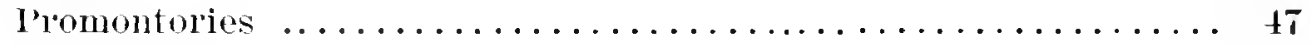

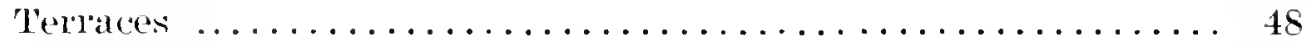

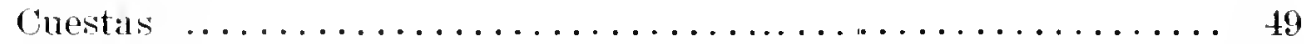

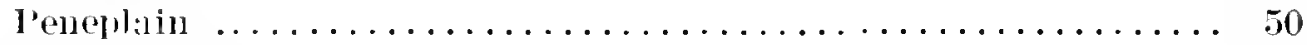

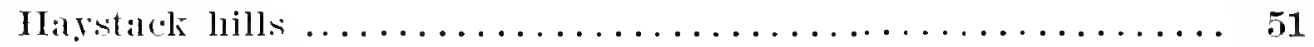

Minclal lesonlees ............................ 53

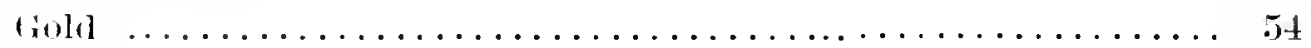

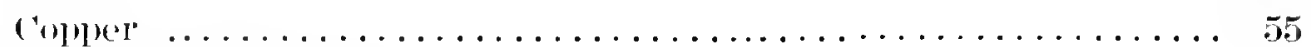

Zinc, leirl and silver....................... 55

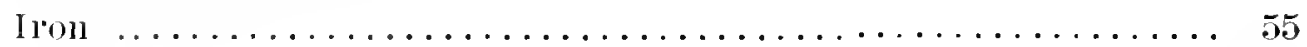

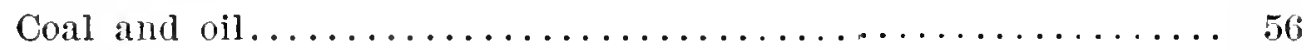

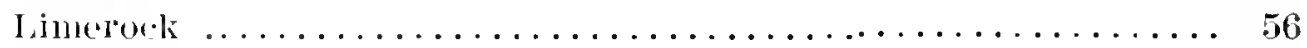

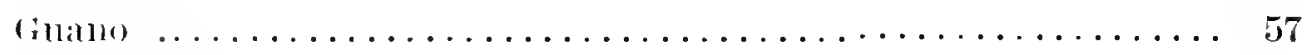

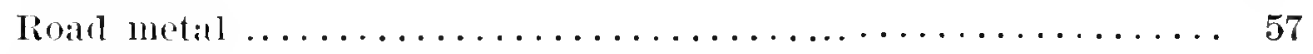

Hot springs ............................ 57

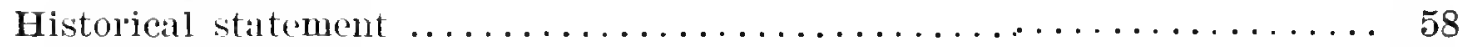

Future problems .............................. 61

Patse mall, ................................. 61

Troologic mall ............................. 62

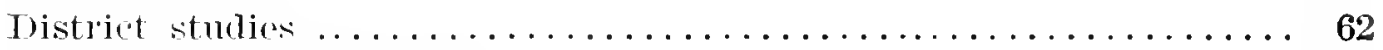

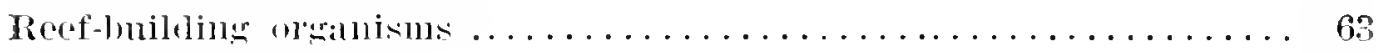

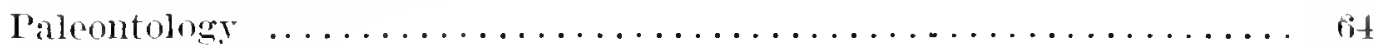

Tertiary subdivision ........................... 64

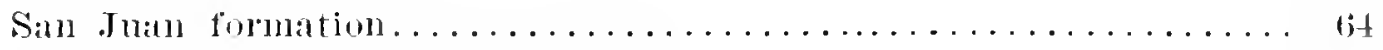

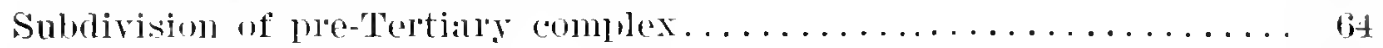

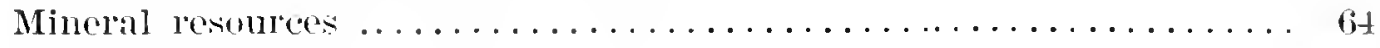

Petrogratiy .............................

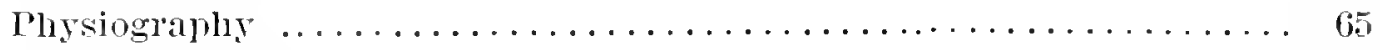

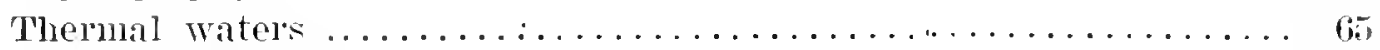

Geologic listury ......................... 66

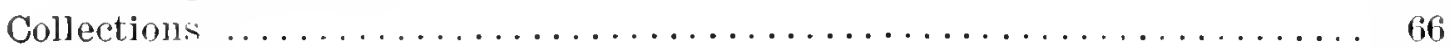

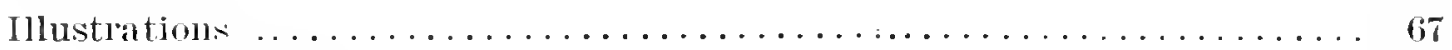

Cross-sections............................ 6 i

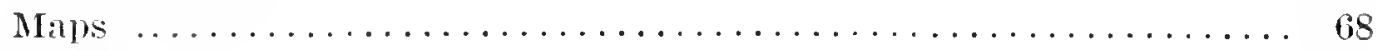

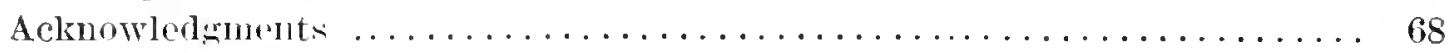

Bibliog

\section{INTRODUCTION}

The lstand of Porto Rico has never hat a thorough or detailed geological study. 'There have been, however, a number of papers written that have described special features or general conditions in a very ac- 
ceptable manner. Most of the writings of this kind are widely scattered in volumes of periodicals or proceedings of learned socicties or pamphlets which in most cases are not readily whtained or consulterl.

From a perusal of these articles, one learns that Porto Rico belongs structurally and genetically to the mombin chain now represented by the isolated islands forming the principal West Imlian gump. Funough work has been done, especially by R. 'T. Hill, ${ }^{3}$ to outline roughly the geological history of the Jsland of Porto Rico and indicate on a map the distribution of some of the formations. In expecially good general description of phrsical leatures, also, is given he II. M. Wilsm. An introductory general description, in larove galt alumg the sane lines as these, will probably serve the present purpose.

\section{General Description}

The Island of Porto Rico is situated in the 'Torrid Znne between latitude $12^{\circ} 5 t^{\prime \prime}$ and $18^{\circ} 30^{\prime \prime}$ north and longitude $65^{\circ} 13^{\prime \prime}$ aml $69^{\circ} 15^{\prime \prime}$ west. It is the eastrimmost and sonthermmost ol the Greater Antillos. It lies within the trate-wind belt, and the constancy of these winds gives the island a remalkably mild and uniform clinmate. There is an abmotance of rainfall on the windwand side, which in this case is the cast end and the morth side as lall west as Camuy. The etlect of the momntains across which these winds blow is to make the sonth side of the island and most of the western portion comparatively arid. Some districts are said to have no rainlall for a whole rear at a stretch.

The Atlantic Ocean lies to the north and east, the Caribbean Sea lies to the south, while Nona Channel on the west separates the Island of Porto Rico from Hayti. Brownson Deep, reaching the profound depth of twenty-four thomind foet below sea level, one of the deepest spots known, lies immediately to the north. Tamner Deep lies to the sonth, reaching a depth of fifteen thousand feet. Although the relief of the island above sea lorel is less than lom thrusand feet, this represents only the extreme top of a great mountain mass which rises above the submerged platform, from which its ral height should be measured. 'The extreme relief difference represented by the summit of El I unque on the one hand and Brown-

2 The writings referred to, together with others that have some description of physical conditions in lorto kico, ale listed at the $\epsilon$ nd of this paper. Those of most usefulness in the present investigation are certain papers by $R$. T. Hill and $H$. M. Wilson, besides a very few other's of less extended character.

3 R. T. HILL: "Torto Rico." National Geographic Magazine, rolume 10, pages 93 to $112(1889)$.

"H. M. Wilson: "Water Resources of Porto Rico." Water Supply Paper No. 39, U. S. Geological Survey. 
-

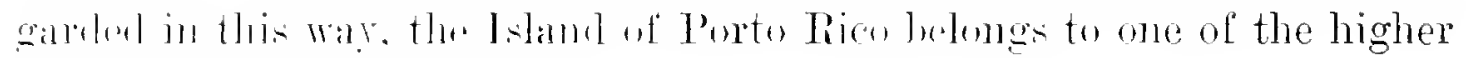
reliel features of the earth.

It is in reality a hally corred summit of a wrat memntain belonging to an east-west chain or range inchding the Guatu lutilles. The gen-

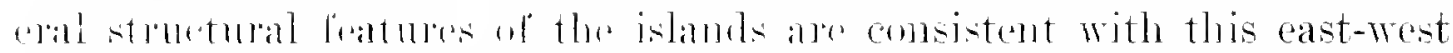

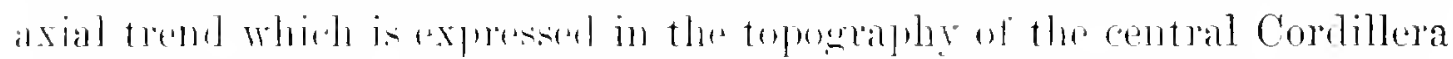
extenting heme the west end nuar lincon. Where it stants abruptly from

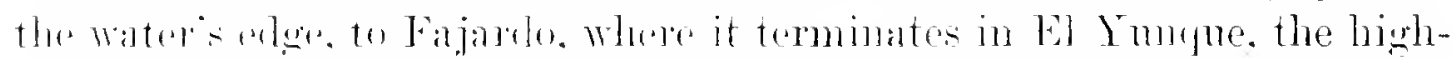
est print on tho istane. The momblain range. howeror. is not so simple as

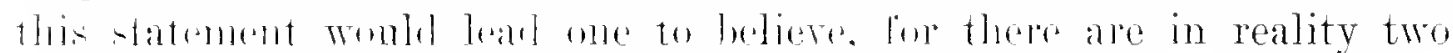

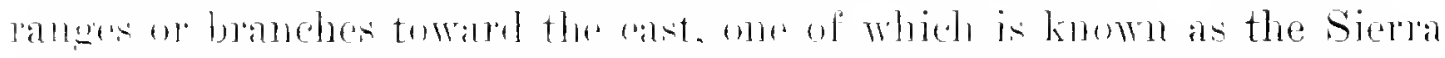

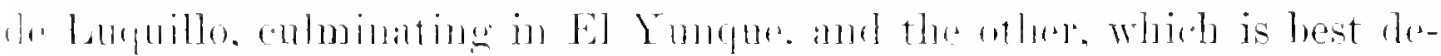

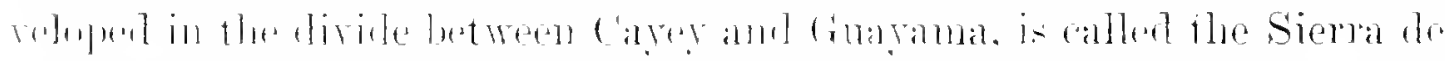

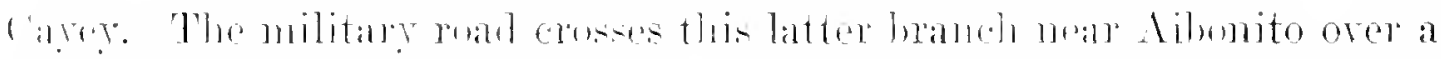

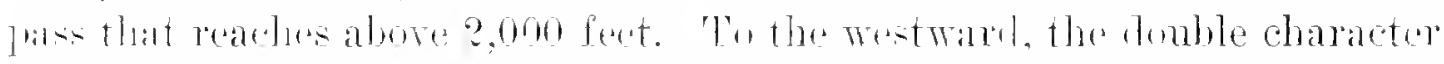

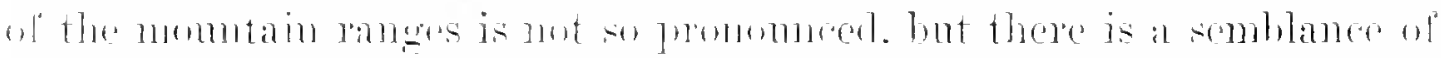

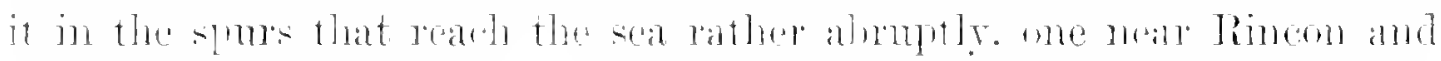

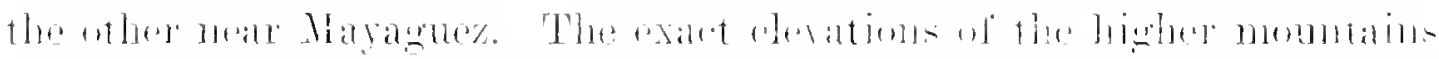

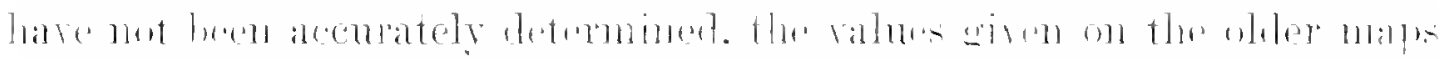

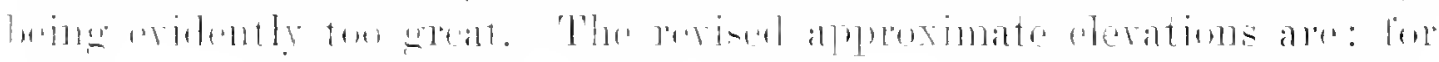

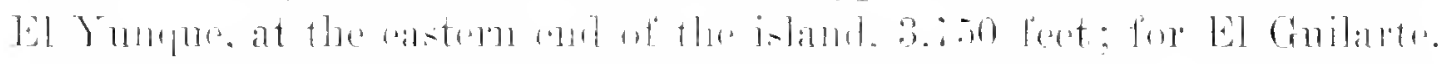

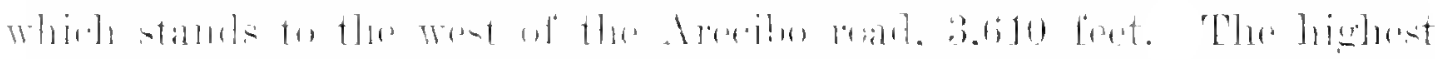

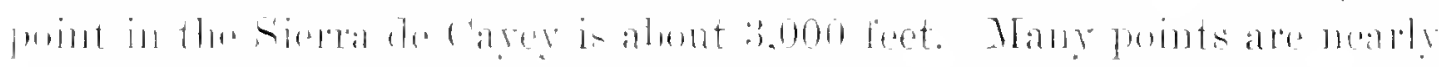

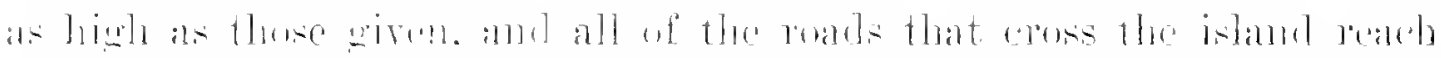

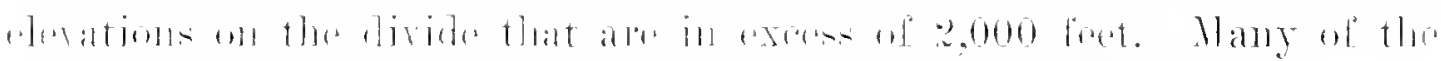

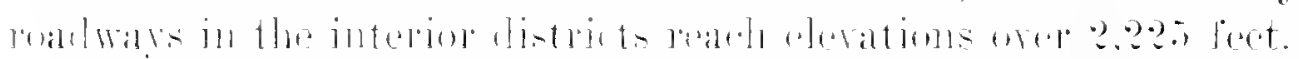

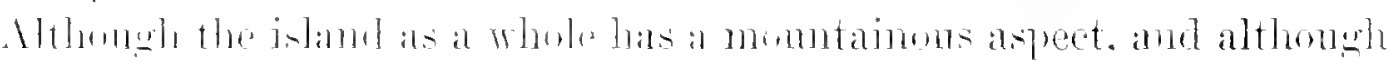

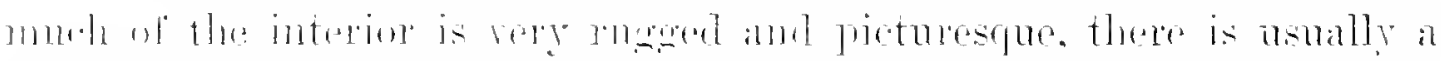

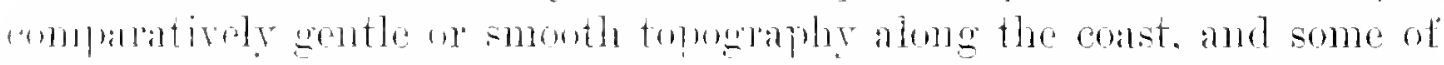

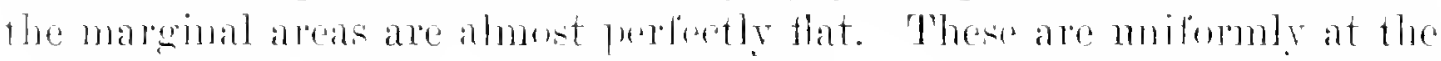

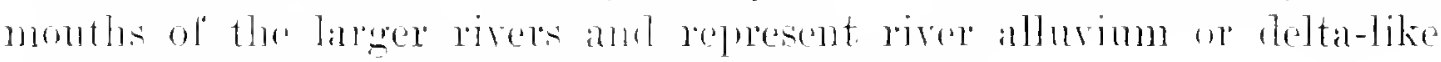

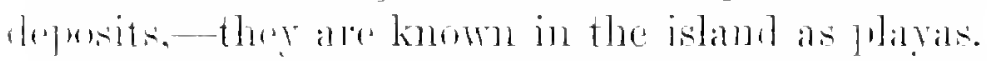

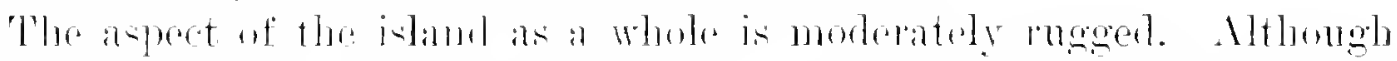

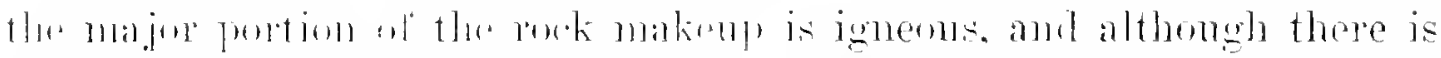

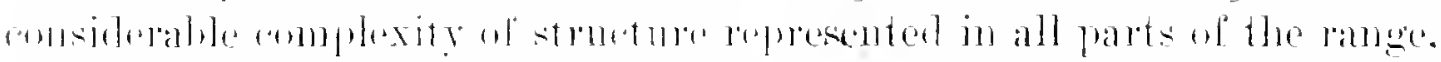

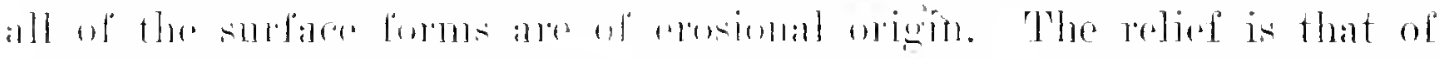
"arly maturity in the interios and perbaps late matmity in portioms of the coastal distriets. Fxeredingly stere sheses are the rule in all parts

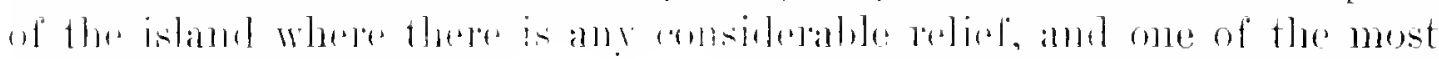

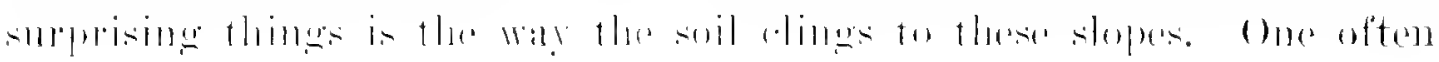




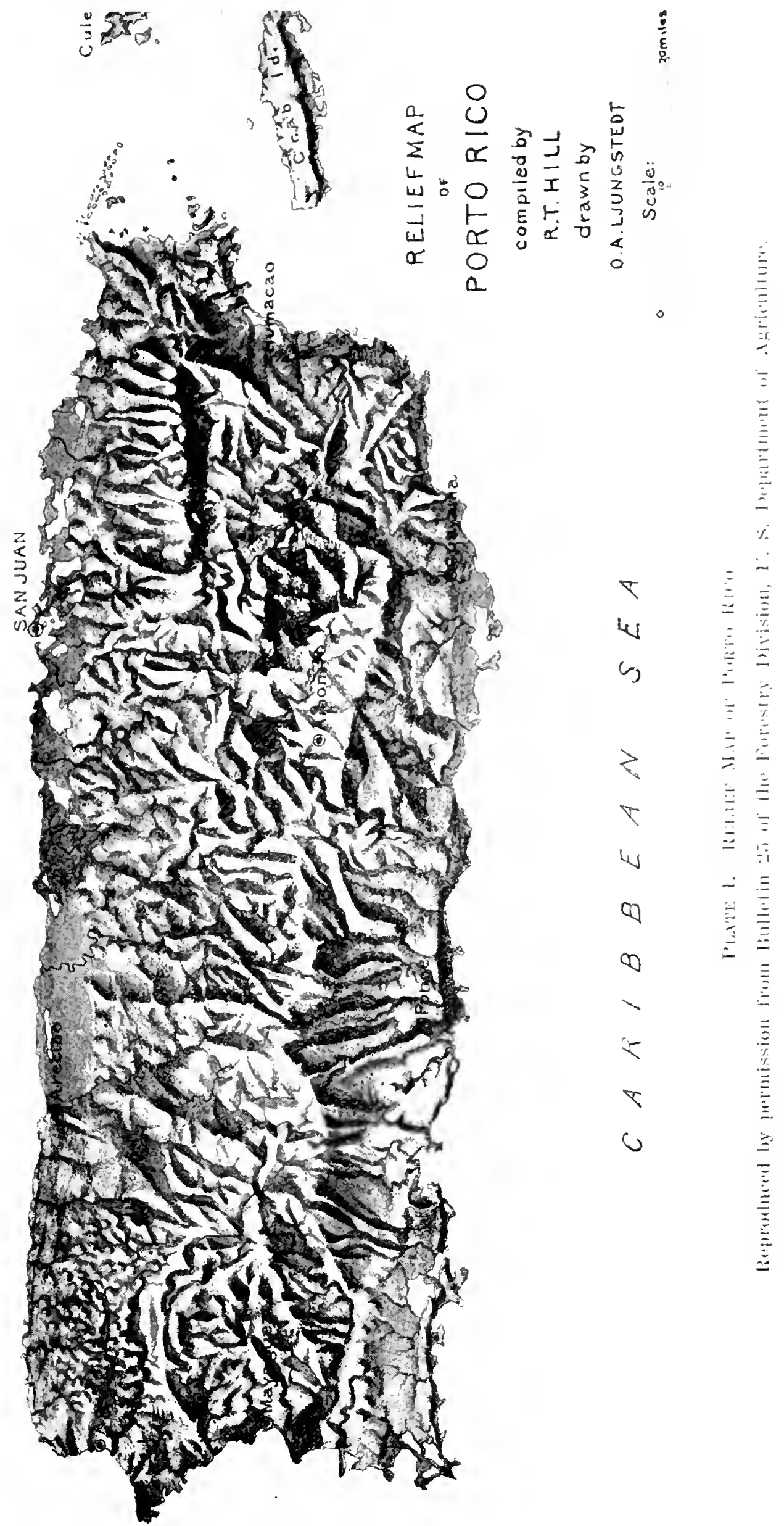


sees sopes of this kind with angles of thirty to forty degrees from the horizontal moler enltivation.

The islands of Culebra and Vieques lie to the east of Porto Rico and are said to be similar in structure and makeup, but neither of them was visited on this expedition.

The streams of the island are numerous and surprisingly large for the size of the areas drainer. Aceording to Mr. Wilson's description ${ }^{5}$ of the water supply there are twelve large streams flowing north, four flowing west, seventeen flowing sonth and six flowing east. Besides these there are said to be 1,300 small streams, and on aceount of the heary rainfall on portims of the island many of them are of larger size than such an area would usually afford. The main diride runs near the southerly margin of the island. so that abont one-thind of the drainage is tributary to the Carihbean Sea on the south, and about two-thirds to the Atlantic Ocean on the north. This nusymmetrical position of the diviling lange is an abnomal feature. the cause of which is the subject of discussion in another portion of the report. Because of the prevailing trade rinds, the rainfall is very mevenly distributer. The east end and the north side are comparatively humid and plentifully watered: in contrat, the west end and especially the sonth side are comparatively arid. In order to overome partly the shortage of water, a large system of irrigation is now being deretoper on the south side of the island. At the east eme, montheast of El Yunque. there is an ammal raintall of 123 inches. On the other hamb, at Cabo Roju. at the other extreme on the somthwest sirte of the island, it is exceslingly dre and in ocosional vears there is said to be not a simgle drop of rainfall. Other parts of the island rary between these extremes. 'The wettest months are September and Torember.

In most districts. the molerlying rock is compact enongh to discoulage much deep water circulation and the stram run-oft is correspondingly responsive to the rainfall. In the northwest corner of the island, on the broad limestone belt extending form Aguadilla to Cammy. there is a prevailing tendency for the surface waters to sink into molergromul channels, learing the surface very much more poorly watered than eren the somewhat santy rainfall would lad one to expect. In some cases. streams developed on the more compact rocks of the interior districts completely lose themselves in underground channels upon entering the limestone belt. and in some cases do not again come to the surface lor several miles. Elaborate eaves and ehanmel-like caverns are common and. in the northern belt of limestone country: there are thousands of such oecurrences

"H. M. Winsox: "Porto Iico; its Topography and Aspects." Jour. Am. Geog. Soc., Vol. 32. p. 220. 1900. 
still preserved that are now wholly abandoned by the waters that formerly oecupied and helped to form them. There are no inland lakes, but there are a few coastal lakes and they appear to he related to the derelopment of alluvial plains or playas and recent elevation and subsidence changes.

The climate is strictly tropical. but it is so tempered by reason of the constant trade wind breezes from the ocean and the elevated character of much of the ground that it is usually agreeable and mild. The lack of great changes of temperature and the prevailingly moist combitions on most of the island have direct influence on the character of the rock decay and disintegration and also on the quality of the soil produced as well as its behavior as a residuary product. Other matters of climatic combitions have little or no bearing on geological probloms and may well be aroided. The average daily temperature is eighty legres: it rarely goos above ninety degrees or below serenty. The maximum tomperature is ninetynine degrees. Extremes recorded for the your indicate a range of forty degrees.

The area of Porto Rico is given as 3.650 square miles. which is abut three-fourths the size of the State of Comnecticut. It is romphly rectangular in outline and in actual dimensions is about thirtr-five miles in average width, and one hundred and five miles lomg fom east to west. It is the fourth in size of the West India Islands and is ume of the most. productive and densely populated districts in Imorica.

Becanse of the areater interest recently taken in sturlying the natural resources and natural history of Porto Rico. it was jullecel to he a suitable time to make a more claborate and detailon study ol the iskand's geological framemork and history. In aceord with this view the New York Academy of sciences organized an expedition which spent a part of the summer of $191 \pm$ on the island. The accompanying deseriptions are based on the work accomplished by this expedition.

\section{New York Academi of Sciexces Explidition}

The geolowists sent to make a preliminary stmily or recomonssance of the Island of Porto Rico left New York on the 1jth of August, 1914. Four weeks were spent in Porto Rico, the expedition returning to New Tork City on the 21st of September. The party consisted of Dr. Charles P. Berkey of Columbia University. Sew Iork, and Dr. Clarence N. Fenner of the Geophysical Laboratory, Washington. Arrangements were made with the bureau of transportation of the Insular government in San Juan for conveyances, so that as much ground as possible conld be seen in the time available. More than 2.000 kilometers were covered by 
the and of this transpulation service and observations were marle in suffi-

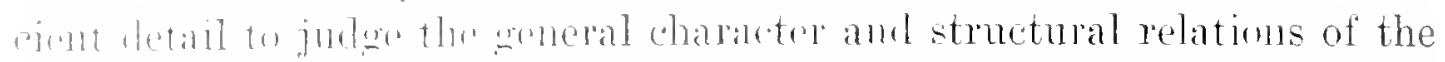
formations croson. In indition to this kind of travel on the roads, short

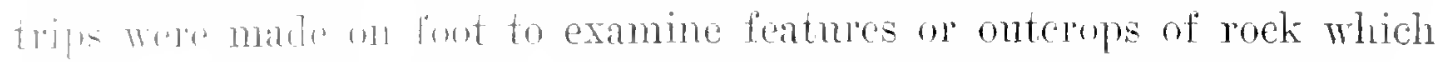

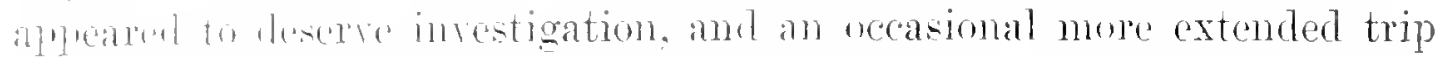
on hurebatek was taken to points in the intorior. With these faeilities

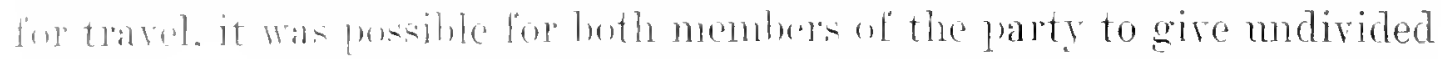

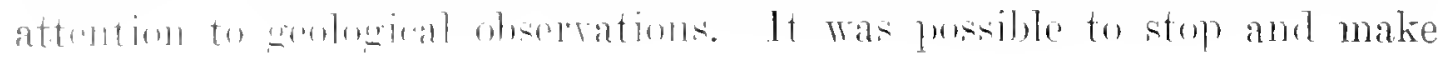

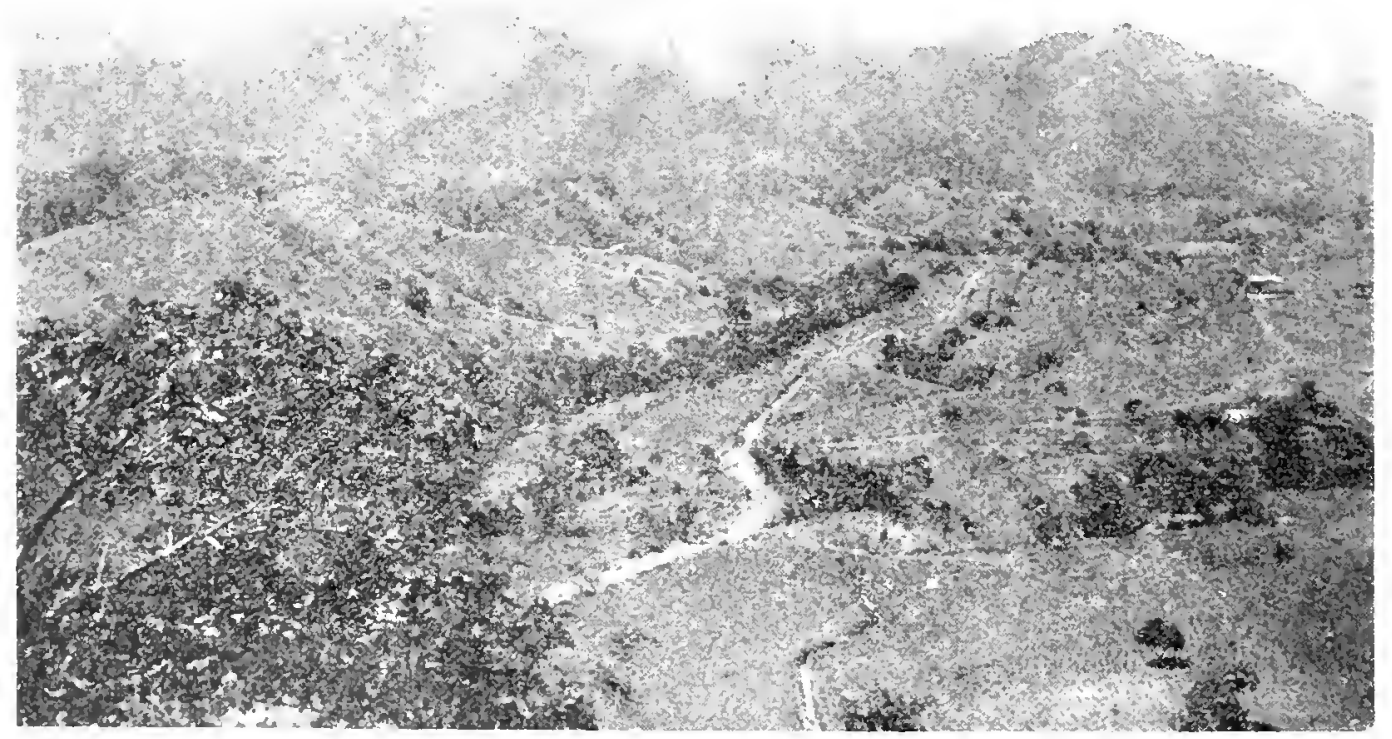

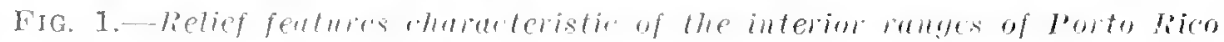

lyntograph takn from the louce-Penuelas road at $K-10$. Inoking northward across

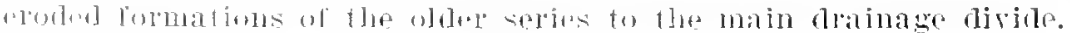

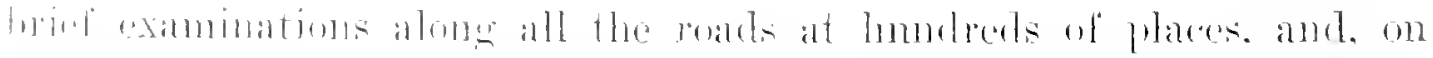

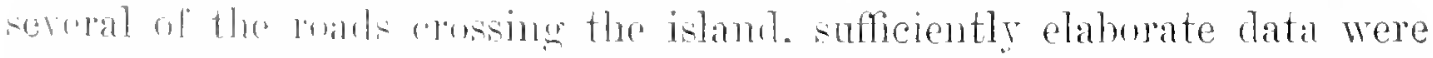

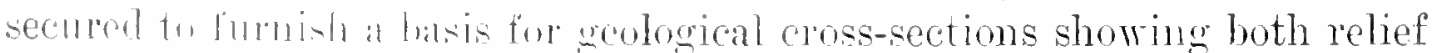
and stmoluml fratum. I complete circuit of the island was male and

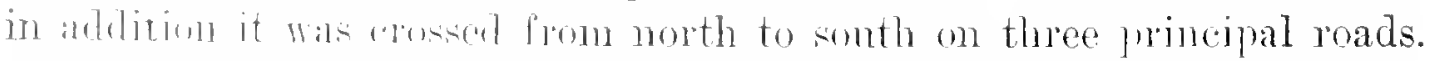

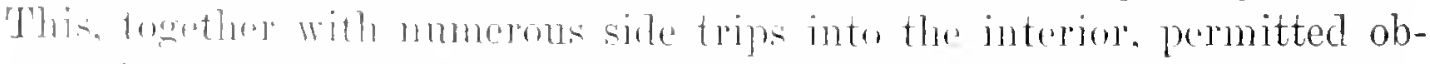

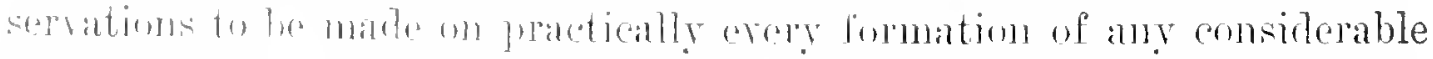

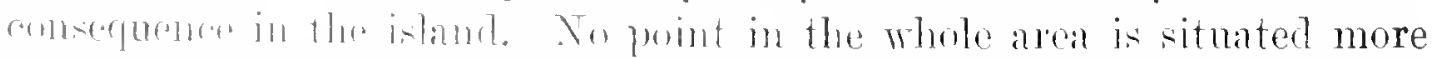
than seron miles lown some loal or other point of observation covered ly thr farty, and, and in those ases. axcept in the extreme southwest 


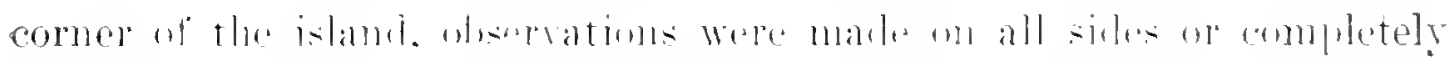

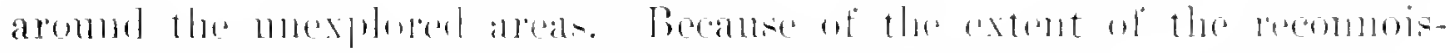

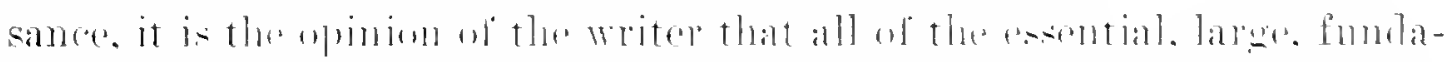

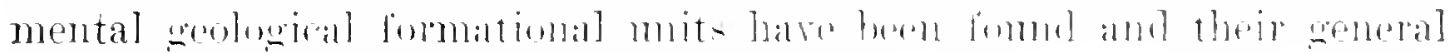
structural relations have heent hetermined.

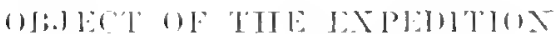

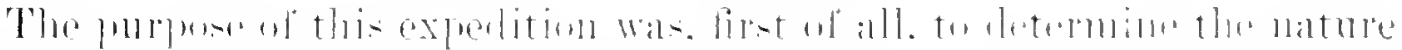

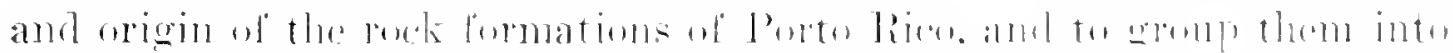

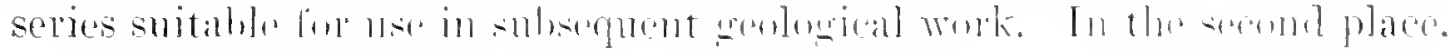

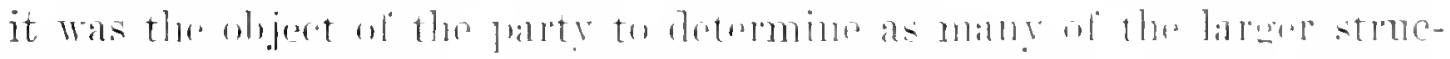

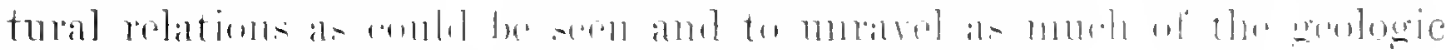

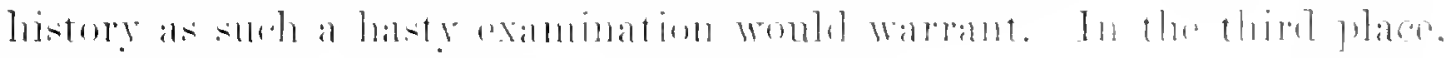

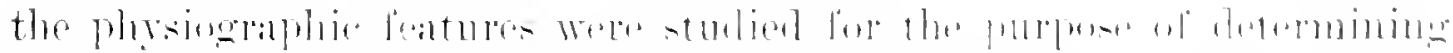

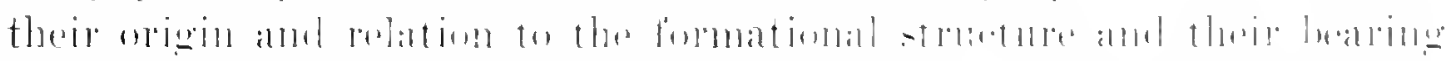

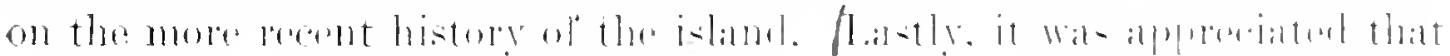

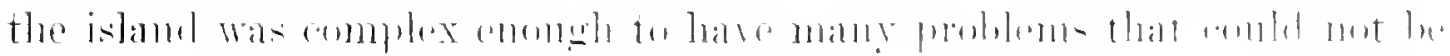

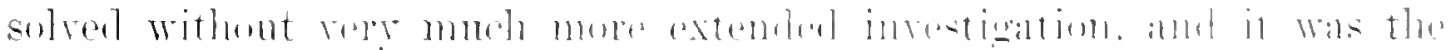

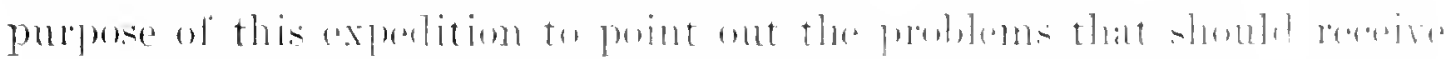

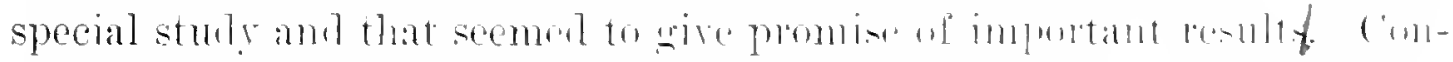

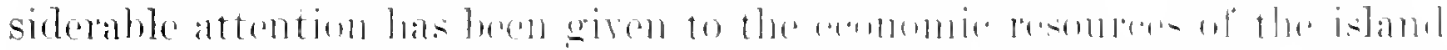

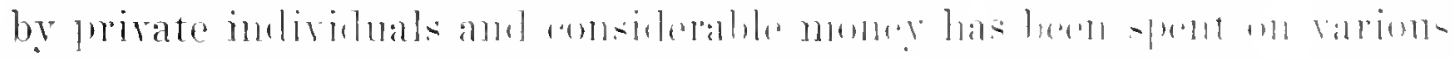

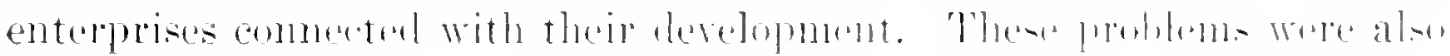

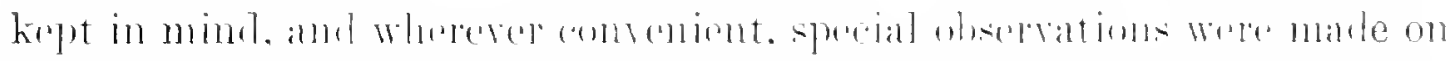

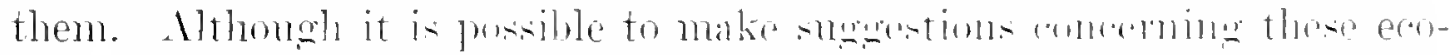

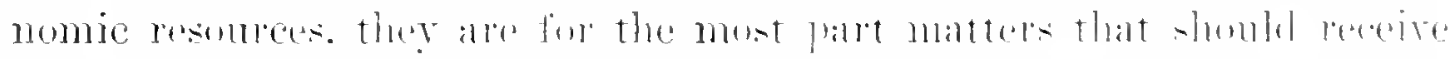

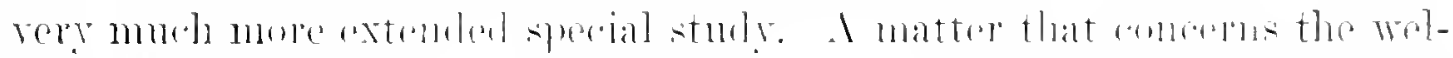
fare of the istand more libertly than any of these is the question uf

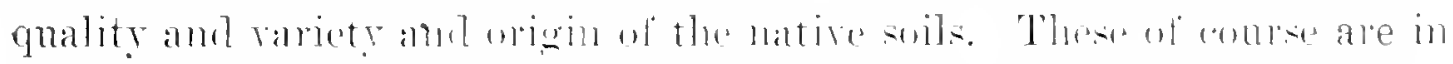

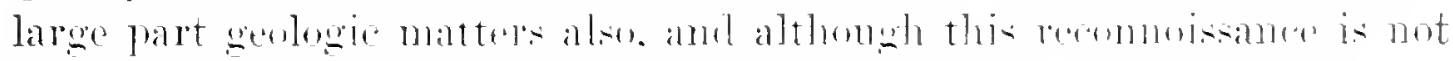
sufficiently letaiden to form the hasis of a discussom of this matter. it is one of the lines of incestigation comnecter with further worts that will have direct value.

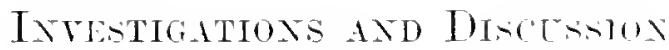

\section{IOCK FORMTATONE}

she most fundamental thing to be deternined at the ontset of an investigation of this kind is to discorer and differentiate the different rock types and the structural mits to which they belomg. All of the prelimi- 
nary work of this experlition was deroted, primarily to this question and collertions were mate for comparison throughout the island. In the beginning. oherrations were made chiefly along the coastal margins becanse of the sreater amount of gromnd that conld be covered and because of the apparent simplicity of the outemost and younger or more recent formations. The chief formations with their representative roek rariety will be discussed in oriler from the youmser to the older series.

In the first place. such a reemmoissance shows that there are two great series of formations separated by a markel meonformity. Both are somewhat complex, but in that rospect the older series is very much more complex, both in lange of composition and number of units involved and in variety of structural relation. than the younger one. In spite of this discrepuney, it is still the most convenient and useful dirision to make, and. lecanse of the strikingly different characteristies of the two series and the great prominence of the structural brok between them, there is no possible ehance for mistaking this fundamental feature.

The whole lot of formational units are therefore orouped under the followi, tro heads:

1) Tounger Series.

Including the 'lertialy shales, reef limestones and reeent deposits.

2) otrer Series.

lowluding a complex moup of formation:al mits,-tuffs ashes, shates, anslomerates. limestomes and a sreat variety of intrusives, all of which

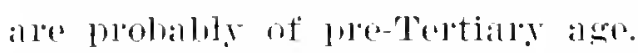

'l'here are several jossible subdivisions of the romerer serios. but in this lisussion only those exhihiting enongh phrsical constaney and character to be usetul in field correlation are taken into acount. These are especially (1) the san . Tuan Formation. a l'leistocene smol-rmue deposit, and $(2)$ the Irecilo Fommation. a sories of reof limestomes and associated shales and marls. Bosides these. there are more local developments that desure snecial discussion. such as the San Febastian shales, the Juana Diaz marls and sandy shales. and the Ponce chalk beds: but in a broad gromping these are all phases of the lareer Irecibo Fomation and it will take hetailed paleontolonir stuly to make the proper sublivisions.

'The older sories has many bormational members and their general relations ane reasomahly well monderstoml. Wut a spstematic subdivision is not yet attempterl. Correlation in this series is still more diffieult than in the other, becanse of the areat raliation in character laterally and the influener of ignenus artivities that prevailed throughout its whole development. Some of the most characteristic of these types will be deseribed. 


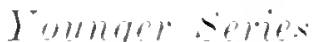

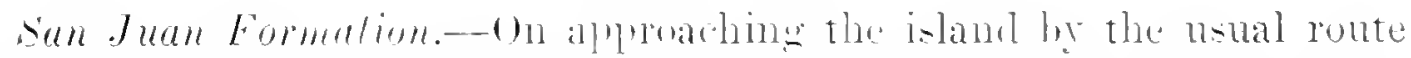
entering san Juan harbor. the tirst ruck whose structural detail can be seen is that on which the citr of san Inan itselt is built. One can see that the formation is made up of strombly belled material wat has all of the structural characteristics of a cros-bedder sandstone and is resistant enough so that it forms, at this point. a promontory extending far beyond the supporting mainland and presenting a cliff face of at least is feet in height. I closer inspection sulports all of these observations as to

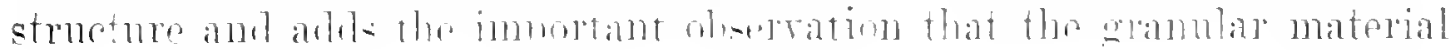

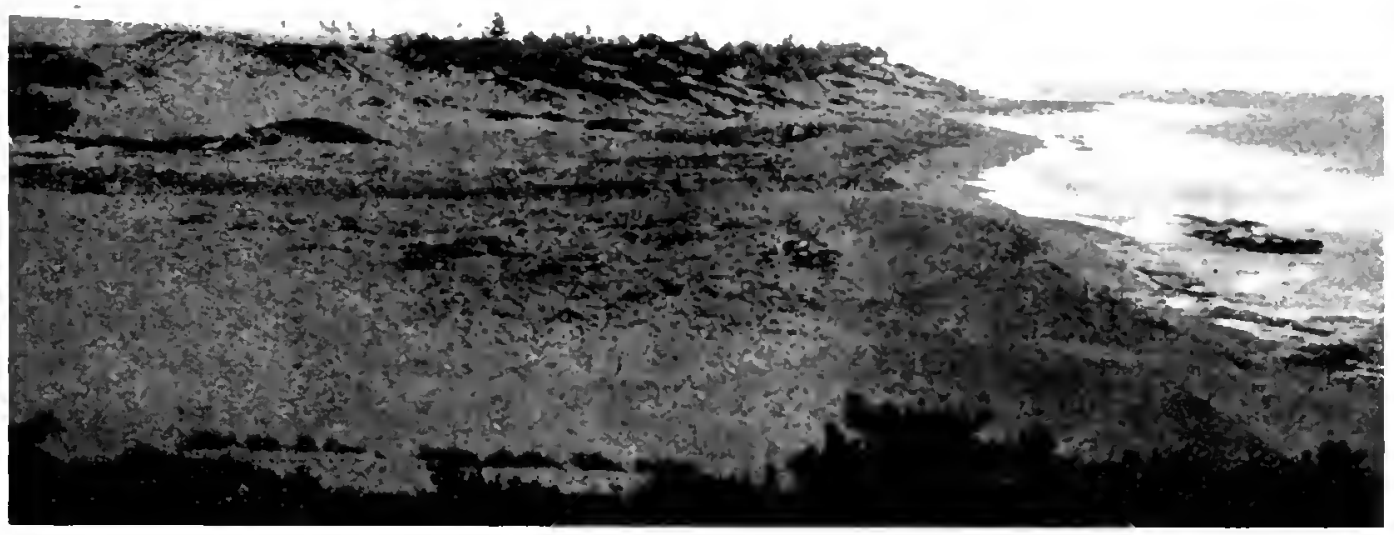

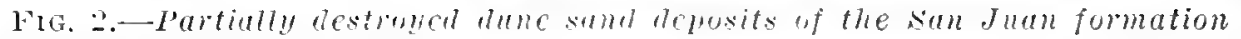

These deposits are a short distance west of Arecibo and are nearly corered with fresh dume sands of the same material.

is, in large part. calcarens in composition and organic in primary on igin. The same type of material. with all of its characteristic structures, was seen at sereral other points along the north coast. Special siudies were also made on sea chiffs of this formation in the ricinity of Arecibo, where the exposmes were so well dereloped that gool photogralhs of the structure comk he taken. One of these is reprodnced as an illnstration of the characteristics of this formation. It shows exceedingly steep cross-bedding structure that measures up to thirtr-three degrees dip. and there are also ocasional struetural limes that are almost horizontal. The rock is exceedingly porous. the grains are unnsually miform in size. am the 


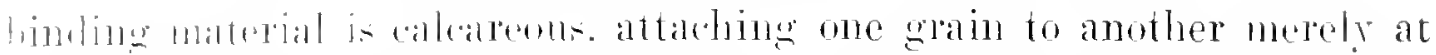
the print of contict. 'The extension of ledges of this kind of rock far'

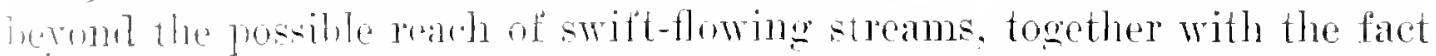
that the ristribution is limited to ertain sections of the north coast, and.

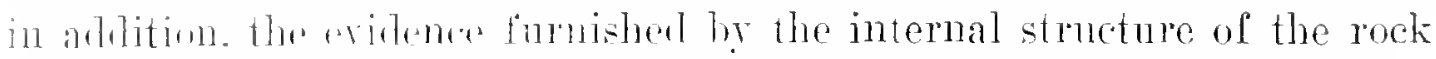
itsoll, Jean to the anduswom that the formation is essentially an old dune-and deposit. Sind dumes are developed on the present coast line from rerg similar matorial, hut none of the very recent dmes are solidified. On the other hand. the San . Tuan formation seems to have been develoned before cortain of the lator alevations and subsidences that affected the ishan in its rewnt history. on that its material is fairly well cemented and its hate extouts below the present water loxel. Its ontcrops also ex-

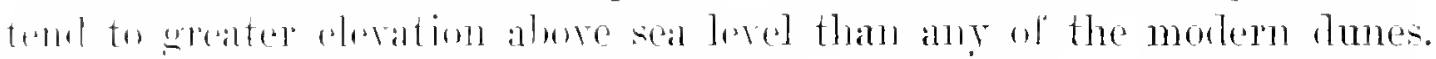
It is judged, therefore, that this particular formation is the most recent

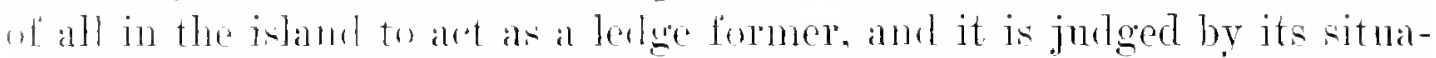
tion and content to he of Pleistoemo age. See arditional description

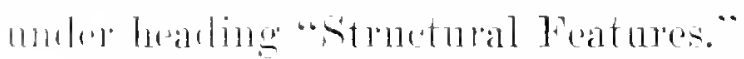

This is the most unnsual formation in the island. It is a type seldom

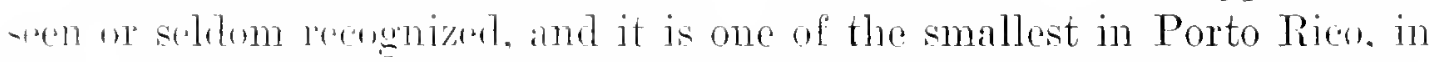
-pite of the fact that it makes such an important showing at San Juan harbor.

Beanse of the prominence of the formation in the city of San Tuan it is sugeged by the writor that the name San. Juan formation be used for it and that this name be comfined to the Pleistocene beds representing

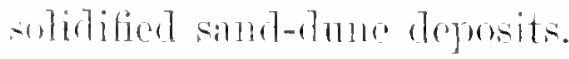

I Fritur formation.--Next below and older than the San Juan formation is a great serios of reef limestones and shell limestones preceded by Gales that form a belt of comsiderable with along the north coast and a pritinn of the somth const of the island. In a large way this series forms a strutural muit. Nhove it in all cases lie the recent alluvial deposits ant the san Inan formation and below it lie the older and more compli(atrol jum and sulimentary rocks. The break between these two reprexputs the whe unconformity in the whole geological column. The Jearinst davelopment of this formation is along the north coast hetween 'T'an. Mlo and Igridilla. Tu this lolt, the massive limestones of the Arerilo, formation attain the greatest thickness observed anywhere on the i-band, but no opporimity was found for determining the amount acculatuly. There is in siglt. howevor. certainly as much as 500 or 600 feet in the lolullis alome the Irecilo River. Tu this belt also, especially farther fowarel the wet. in the viobity of lares and San Sebastian, there are un-

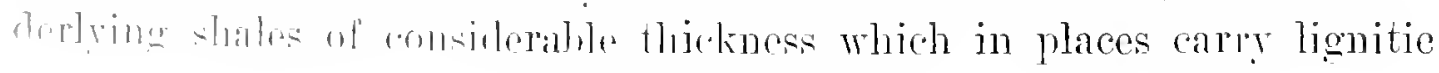


material and which have been the object af some exploritory warls for coal. It is evident, from ubserations mate. that the shale beds of the Arecibo formation vary greatly and in some places are antwly wanting.

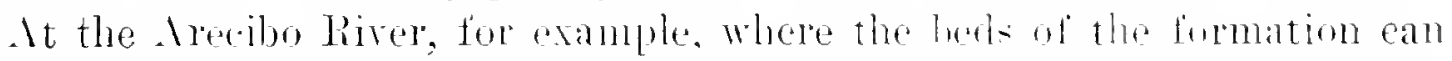
be seen well exposed in the river hintls, there is no shale derelopment at

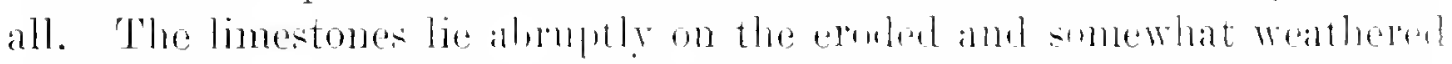
surface of the older formations which at this point ale reprosenton he

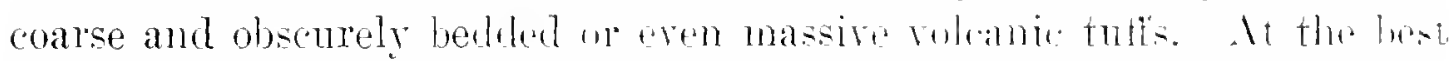

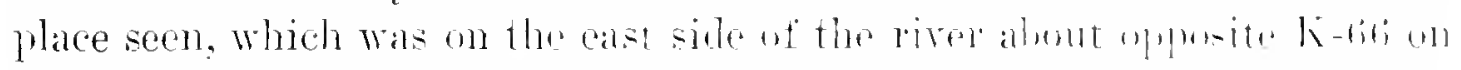
the Arecibo road, there were a lew foet of transigion mat rial betwen the

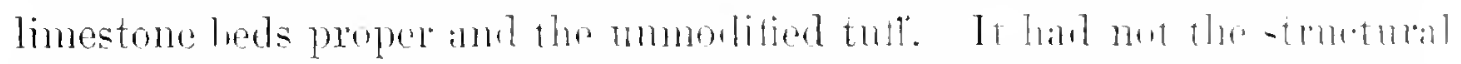

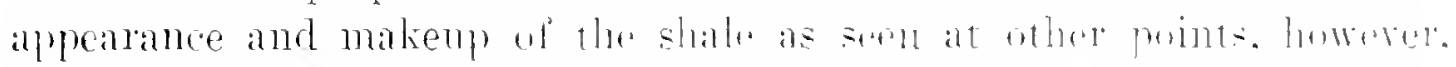

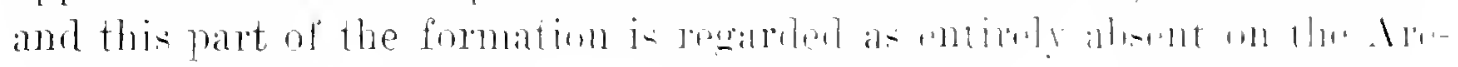

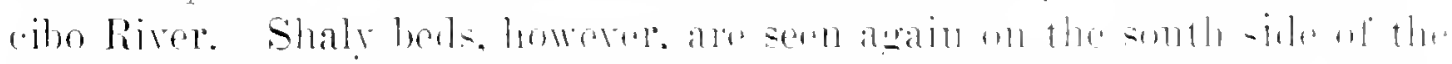

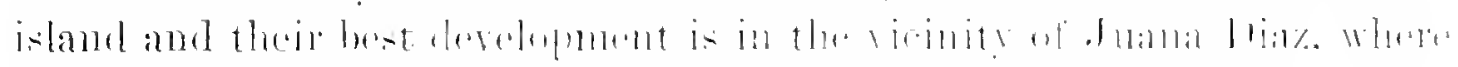

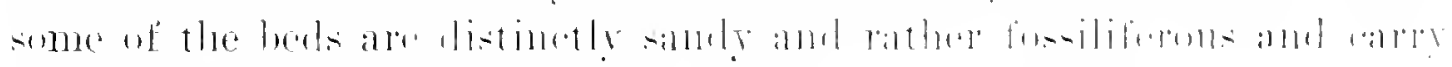

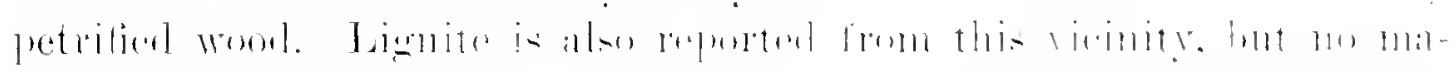

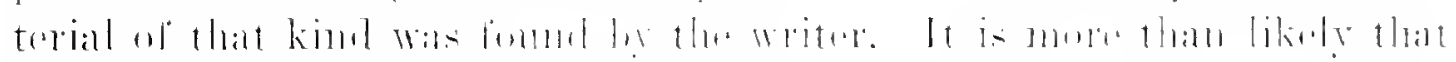

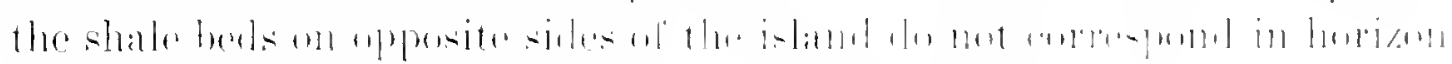

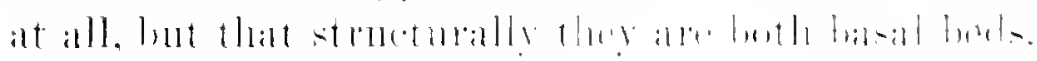

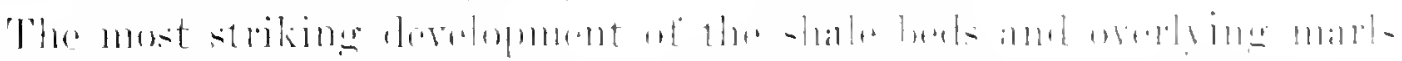

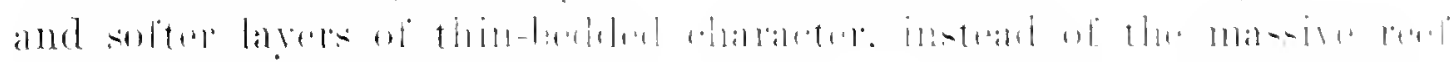

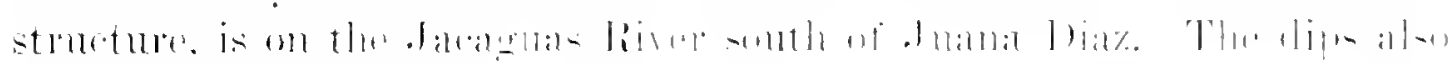

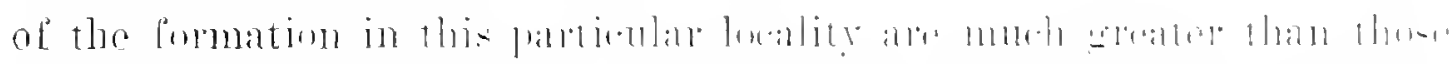

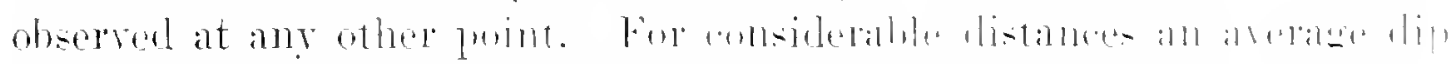

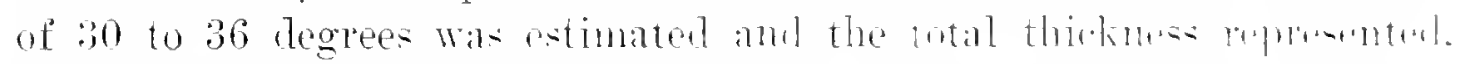

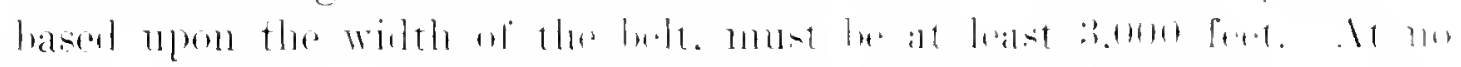

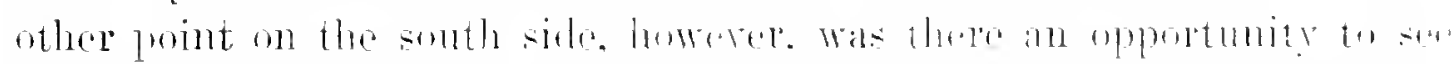

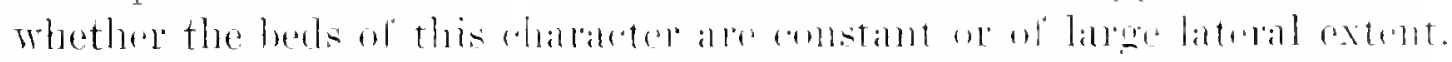

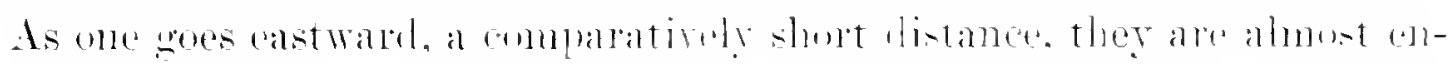
tirely ladsing. On the Desalalmado River, whieh is only ten kilometers to the east, the underlying blder series of tutis and intruted shales am limestones were followed to a distance of two miles senth of thr military road, whereas at. Tnana Diaz the hasal shales of the Irecito formation begin a half mile above the military road. It appears, therefore, that the

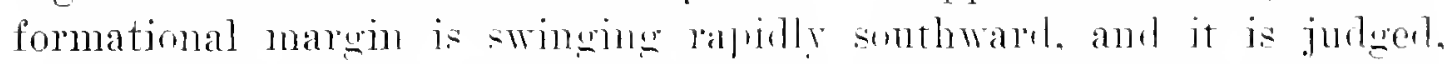
from other observations made, that there is alnost nothing of it represented at a distance of twenty kilometers to the east, or, in other word.that the formation loss not extend farther wat than the ricinity of salinas. At one other point on the sonth marein of the iskme. there is an

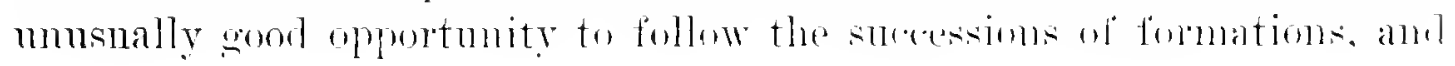


that is in the ricinity of finduica. Limestones belonging to the older sores ocem immerlately sontl of lanco and are very strongly developed there. The hills in which these heds onterop extend sonthward almost

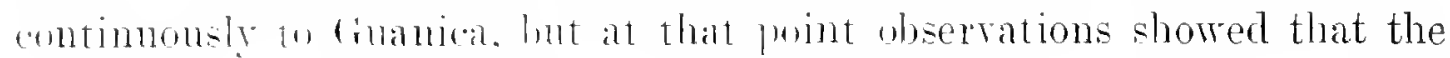
formation bat changed and is arctually pat of the reef limestone of the Mrefilo formation, although it is posible that the large fault observed west of Ponce ma! piss thromgh this a rea and olsoure the other structural

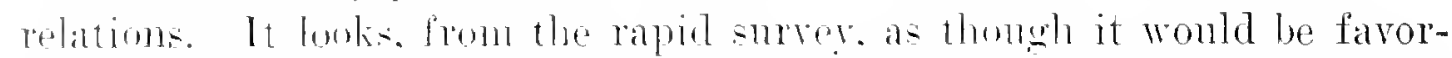
alole for some of these allitional stulies of the chatacter of the lower Jeels of the Irecilu formation. Between (inaniea and . Tuana Diaz, wherores the innow nargin of the Arecibo formation was seen, it was hounded

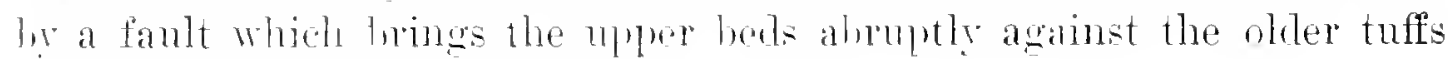
and shales of the pre-Tertiary.

'The formation fumishes an abmulance of fossils. 'The lower portion "r the lower beds on the sonth site of the jiknd. as seen at Tuma Diaz, sem to he the most momising for a detumination of the age of the beds of the formation. Wigher beds. forming a chalky white limestone to the west of Ponce, are also rorr fossiliferoms. Int in this area ther are sepa-

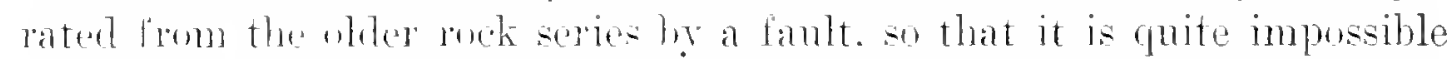
to toll how fas ande the base of the formation these bods may lie. It is judged that the portion of the formation seen at Guanica is a still higher morizon, lut the exact age values have not hen worked ont. The total thickness of the whole Tertian series on the sonth side of the island is very great. It wo wimated that the shates and mals and limestones in the ricinity of . Juna Diaz most certainly amount to three or four thousand feet. For a long distance along the Taragnas River south of Tuana Diaz, the buts stame with a dip of apponximately thinty-five degress toward the sonth and throughout the sreater portion the character is notably dithout from the heds nomming tarther to tho west whide are judged to orerly them.

To the east of San . Tuan. along the north coast. there is murble less prominence of the Alecilon fomation and after passing Rio Piedras it in no place onsses tho main roar. There are ocasional hills somewhat similar to those charaterictic of the bankape of Baramon and ricinitr, lut they do unt reakh to so great a height and are separated by rery much lareres stetches of low around. The stromgest derelopment of this formation sous to the cast of San. Tuan is that along the Grambe de Toiza.

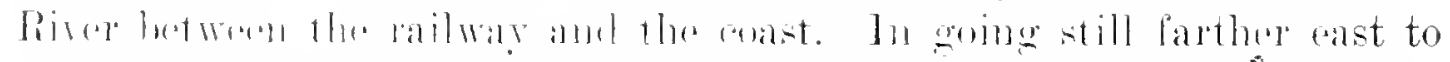
the virinity of Tuquillo. Hu imner marain of the formation passes out to sea and the older formation reaches the shore. From this point around the whule castrom ond of the jsland no more outcrops of the Arecibo for- 
mation were seen, and this is true also of the sontherly side coming from

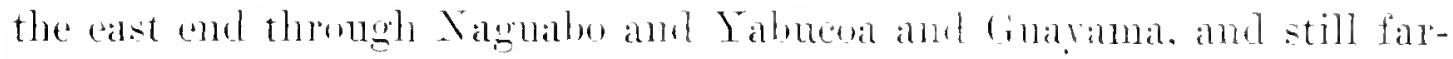
ther west to some undetermined point hetween Guarama and Santa Isalbel. 'There may loe, howerer, ocemrences of this formation underlyng

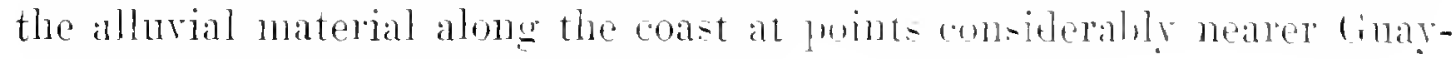
ama than the outcrop mal imlicate.

The formation as a whole is escentially a strurtural muit. Ahthomgh

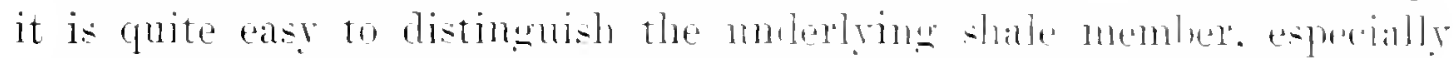

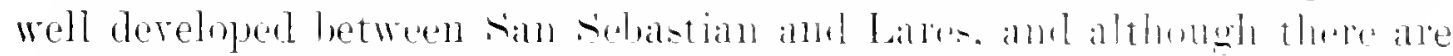

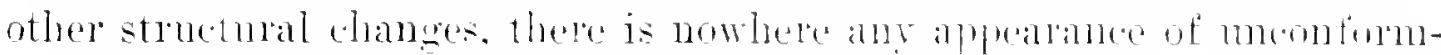
ity or marked beak in thr suresson. Besiles the shale member is not everywhere developed and. as a matter of lart. is seltom seen in malmo the formational homalaries. In somp places, it is definitely shown to be absent. so that it seems mowrbinted to remesent this member as an inportant part of the formation. in far as aral distribution is concerned.

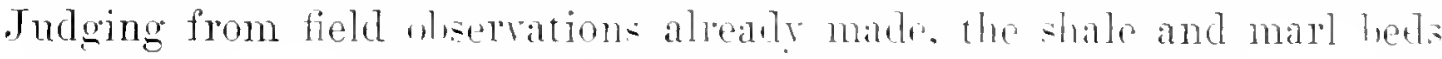
are more extensively developen on the suntl sile than elsowhere. But this is based on obscrations in one particular area and the member annot be traced rery fal in cither direction beause of nther difficulties. The beds lying above the shales and representing the part referred to as a more massire limestone portion are probably susceptible to consinerable differentiation on the basis of fossil content. and it is entirely posible that a rather complete range of 'Tertiary horizms may he determined after complete paleontologic study. In the field. howerer. and on the hasis of structural factors. there is no apparent ground for subdirision. In this discussion, therefore, the whole series of heds, from the moonformity at the base to the allurimm and San Tuan formation orerlying it, is referred to as a single formation and. on accom: of its extensive derelopment in the region abont. Ireciho, it is suggester that a smitable name ronld he the Arecibo formation.

Some parts of the formation show the peculiarities and content of at coral reef, and these portions have the most irreunlar and most masivir structures. Other parts show bedding structure more or less perfectly dereloped, and throughout the whole formation here and thele. at irregulin intervals, and usually of mly very limited extent. there are more shaly facies. It is the opinion of the writer that this irregular distribution of shaly beds is responsible for one of the peculiar topowaphie features developed in the belt underlain by the Arecibo formation. This is the occurrence of almost perfectly flat soil-corered areas of no rejy great lateral extent at different levels, above which the numerous small knobs or hillocks of limestone rise, giving the peculial haystack-like topngraphy. 


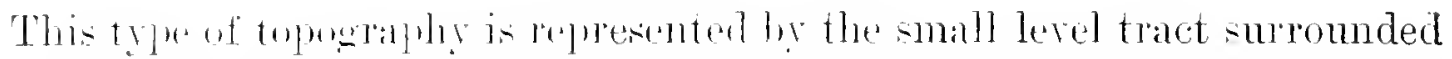

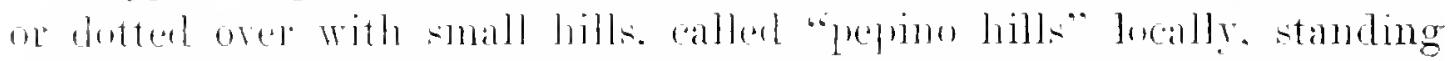

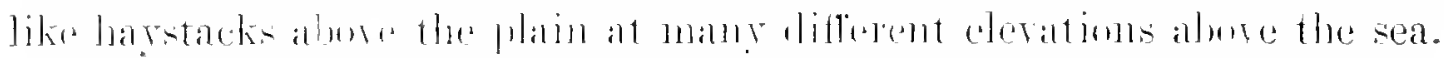

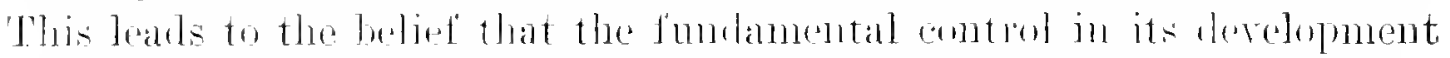

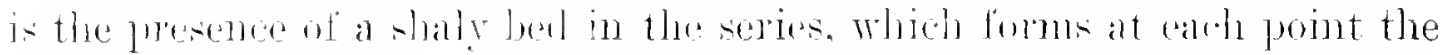

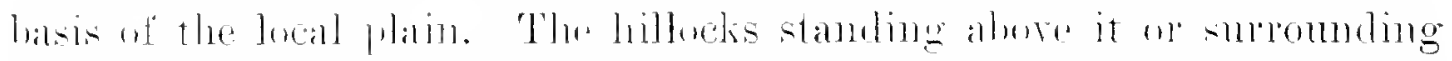

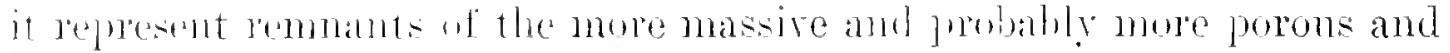

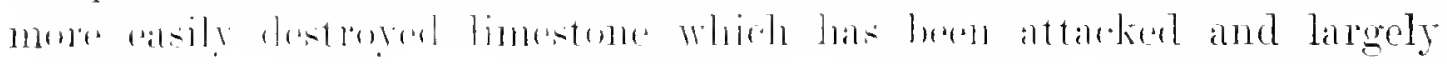

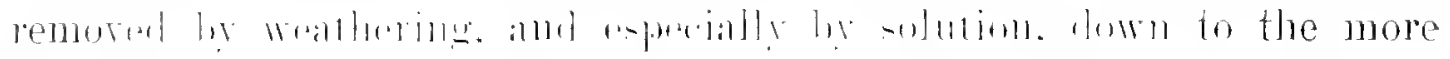

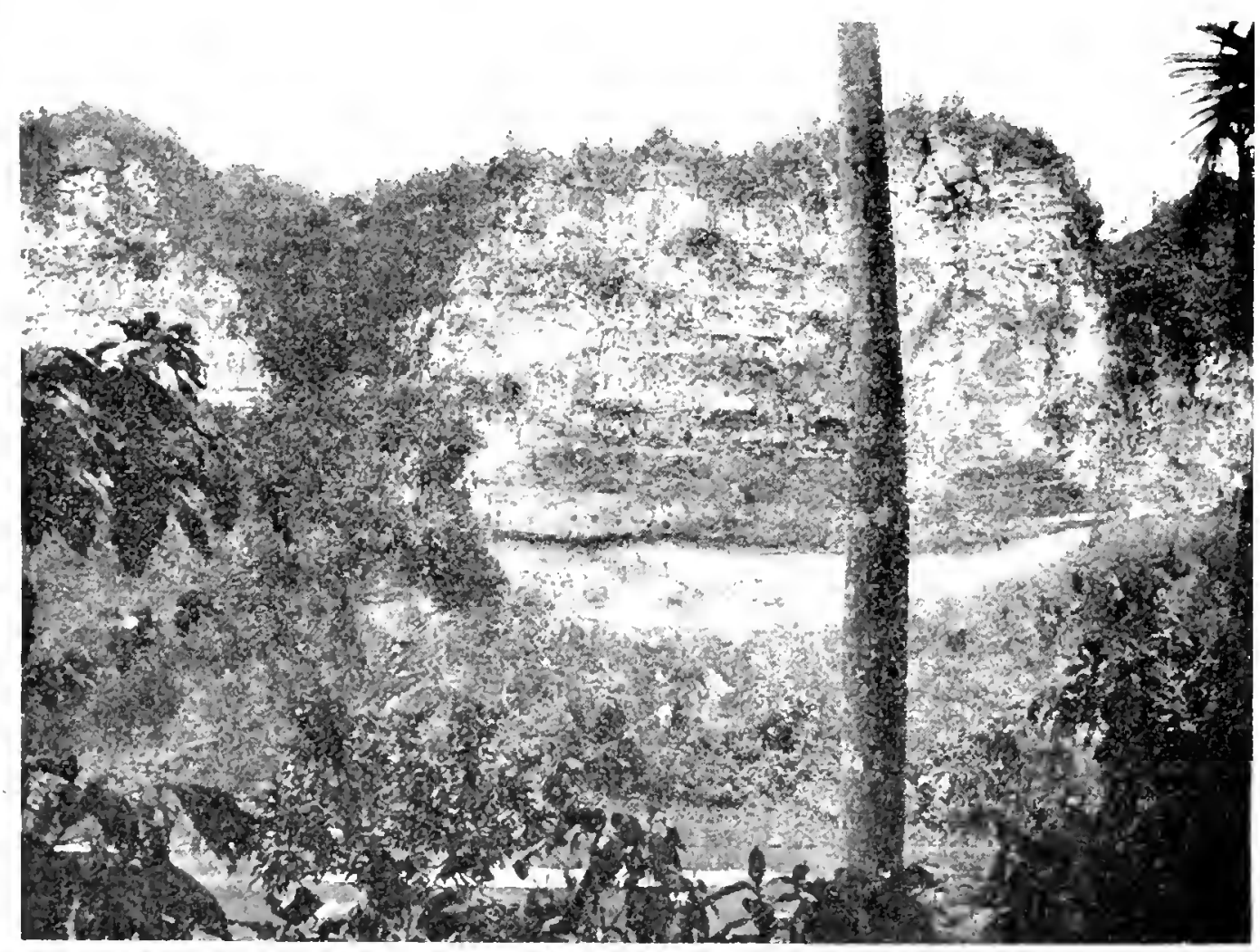

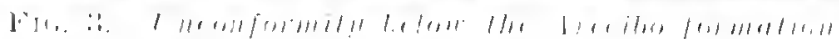

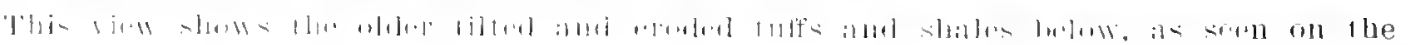

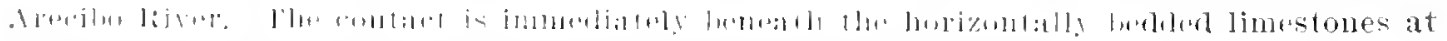

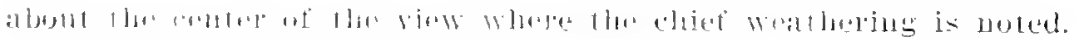

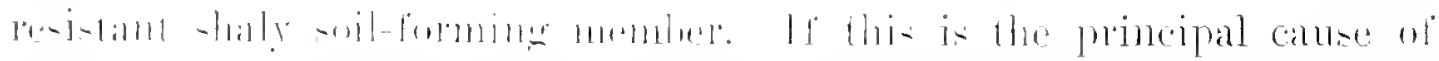

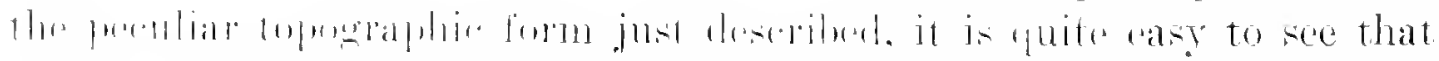

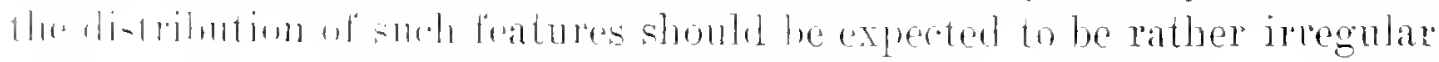

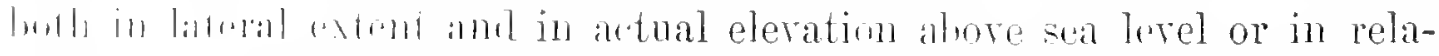

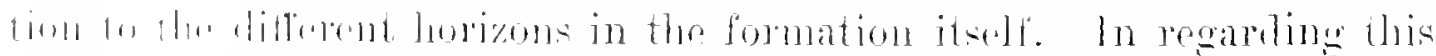

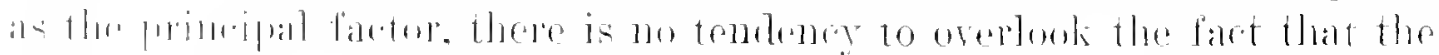

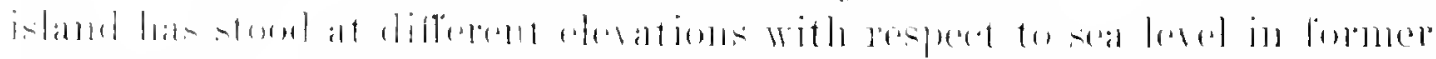

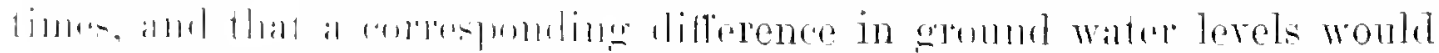

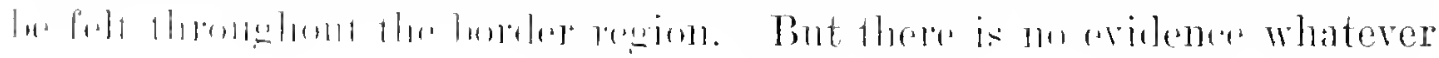




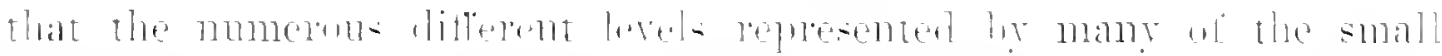

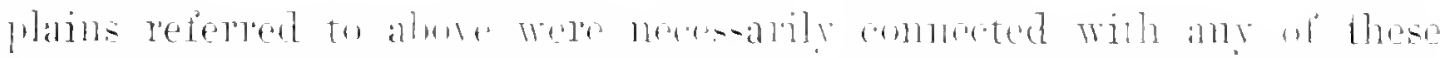

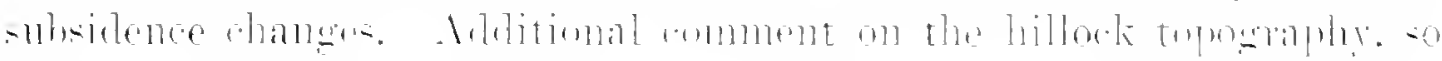

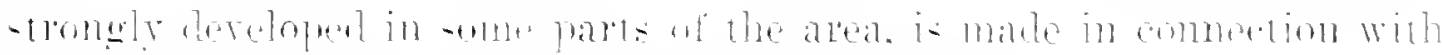

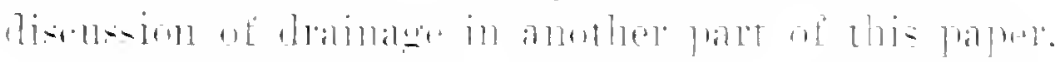

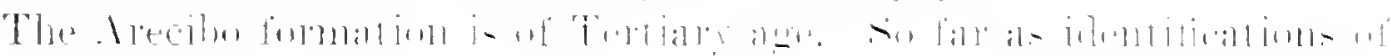

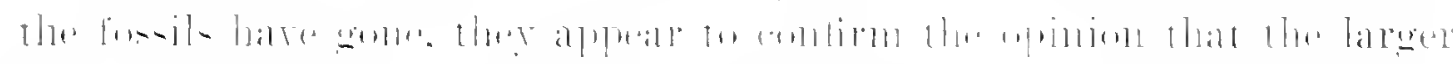

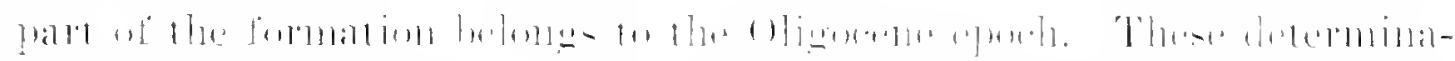

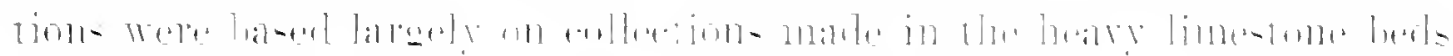

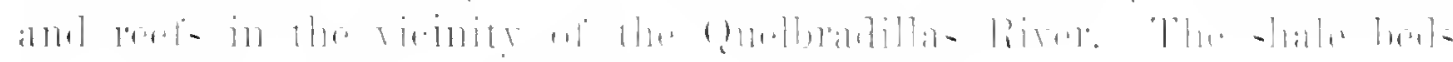

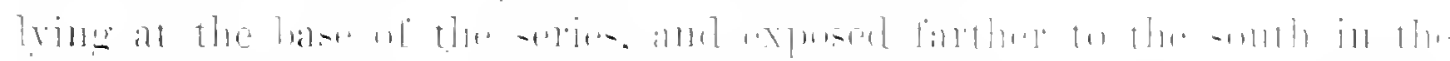

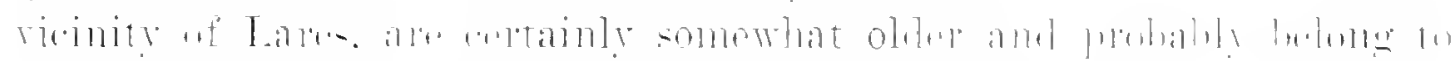

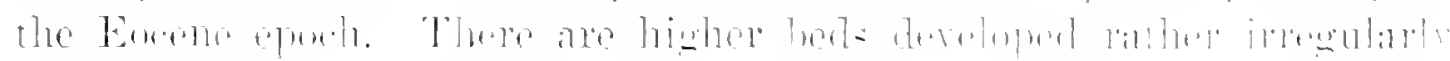

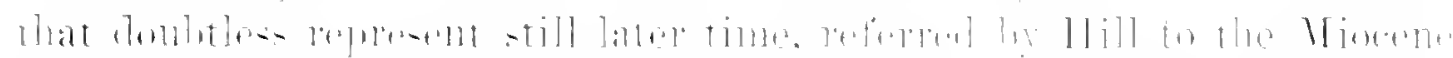

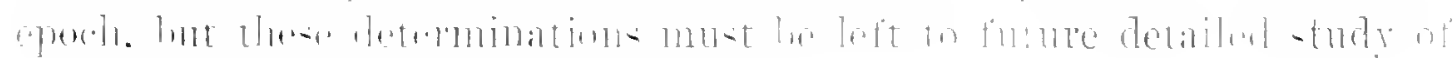
the fombition a a wholu.

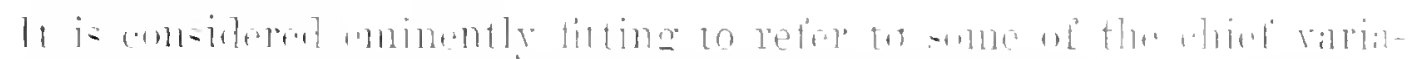

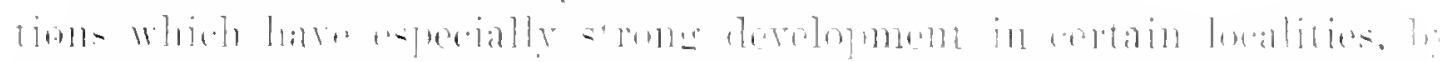
- ]

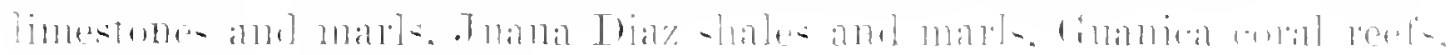

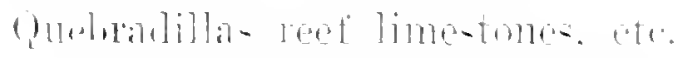

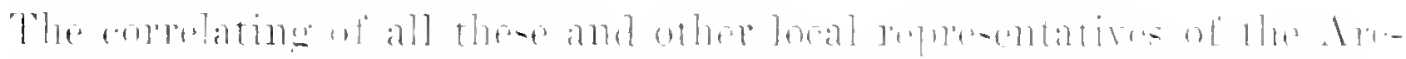

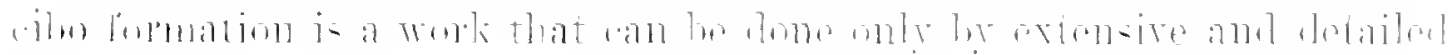

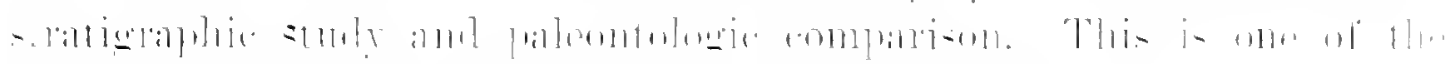

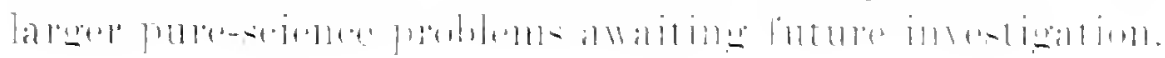

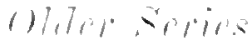

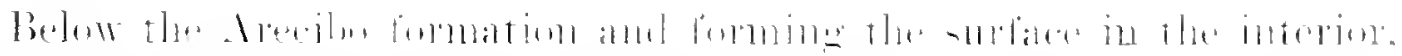

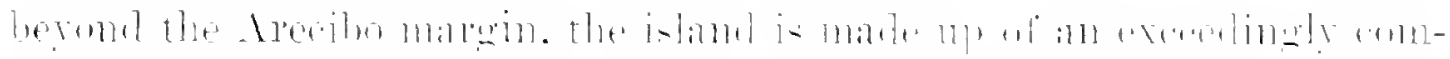

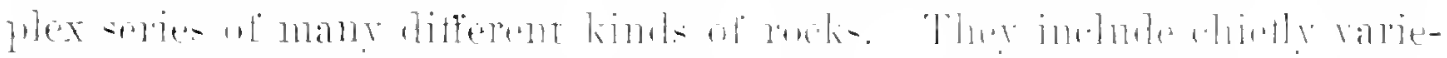

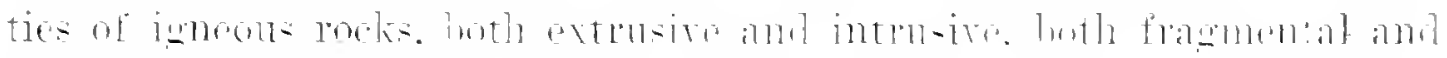

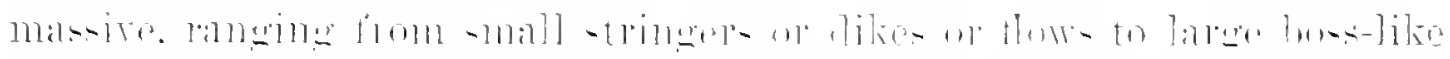

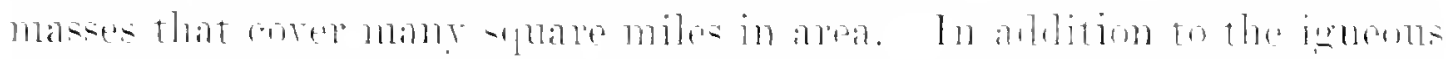

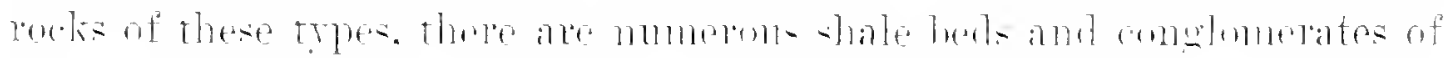

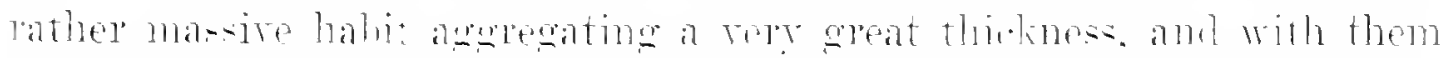

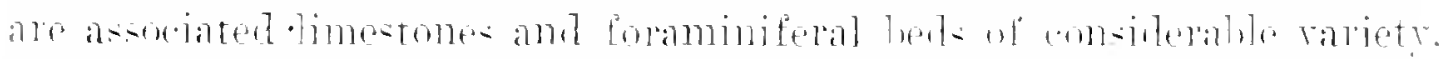

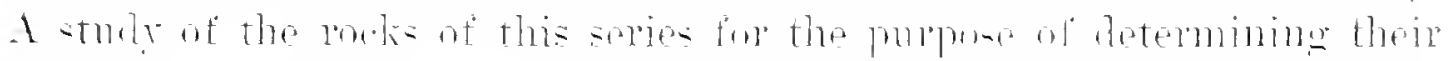

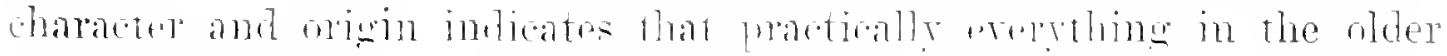
series except the limy portions of the shales or the line-tones proper are more or less directly of igneous origin. The coarsel materials and those leas affected hy any somolary proceses are the tuffs which are of direct 
voleanic origin and are excedingly abnotant and wonsive. They are found at intervals in all parts of the series and it is impossible to saly that they ale either more or lese athment in those portions which appear to be older, mither than in those which aplear to be romper or higher in the series. The dosest associate of these materials is the bedded tutf. marle up of rolcanic framents which have been sommolut assorted by surface ageneies so that they exhibit some solimentary sturtural charac-

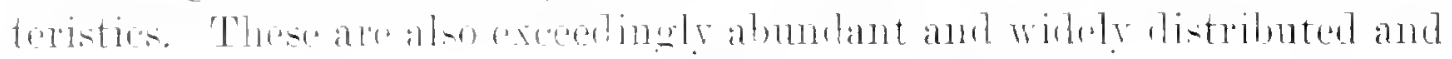
they pase he incensible gratations of finer and fine matrials into tliose

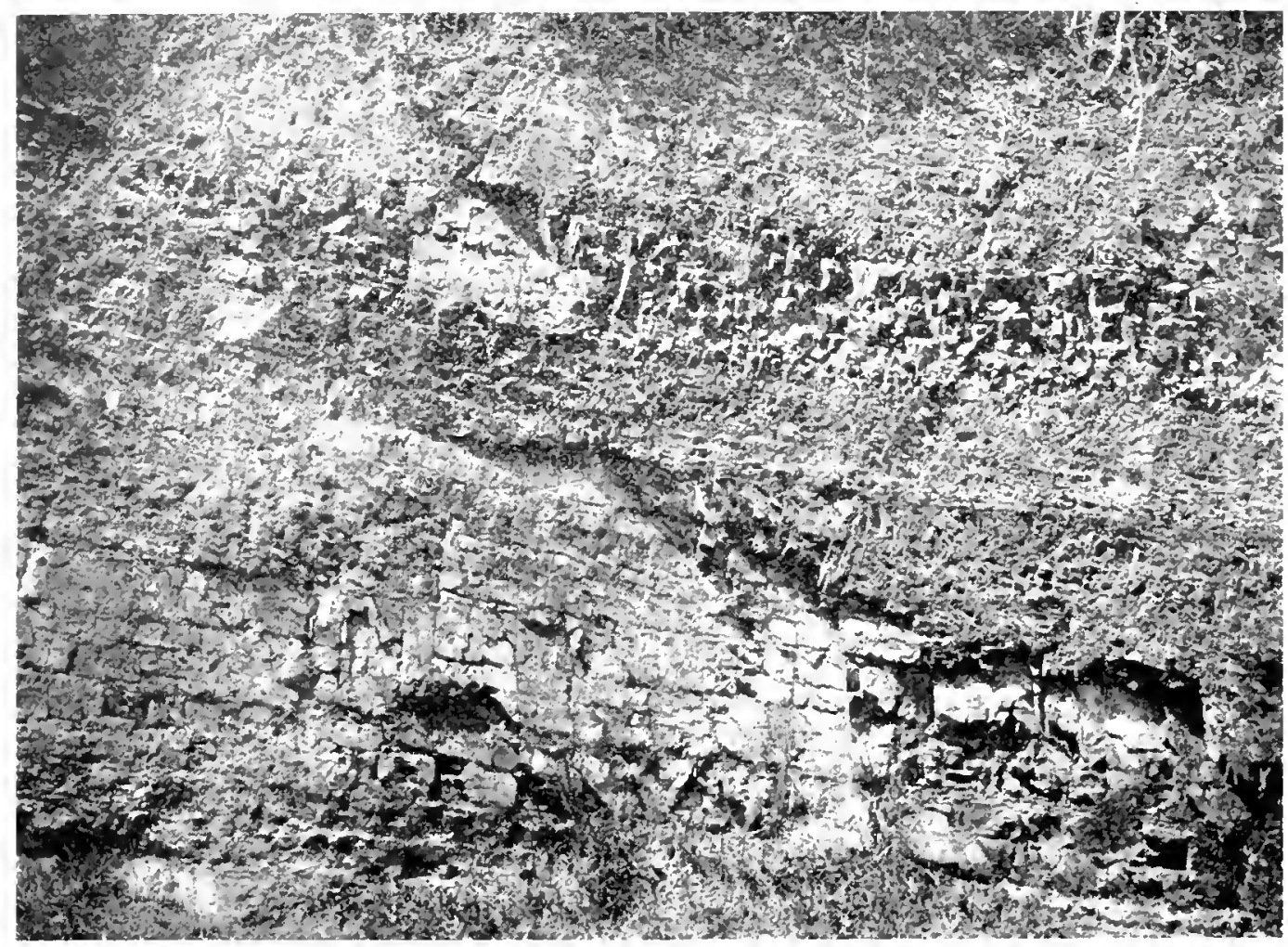

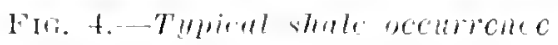

This is swell along the roarl between lonce and Penuelas at K-10. The beds at luis point lie in a less disturbed attitude than is usual in members of the older serios.

that are recognized as true ash beds. Most of these have become so thoronghly cemented, or so much moditied he serondary attack, that ther now

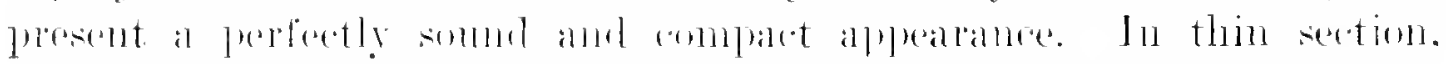
howeres. it is easy to see that the matorial is wholly roleanic and that the menting is the only secondarly modification except that having to do with the limbling, induration or alteration of the rock. The ash beds are probalily rese relatives of the so-called shales.

shales.-lineks of this trpe are dereloped characteristically at Fa-

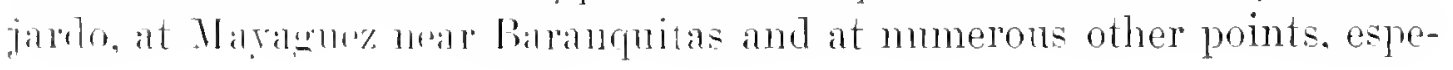


cially along the divides towath the wert. It the two prints first mentioned, in particular, they are light relluwish w redilish in color. rather porous in structure, strongly bedded and have a prominent blocky fracture habit. The exact rhacter of these rocks is a question under study at the present time. Jut enough las been done to show that, in their present condition. they have heen oxidizen to the rellow ar red color, and have been leached so that they have a poroms strueture and light woight due to the remoral of at least a part of some wortituent that is more readily suluble than the rest of the rock. Wioposplic comprison with

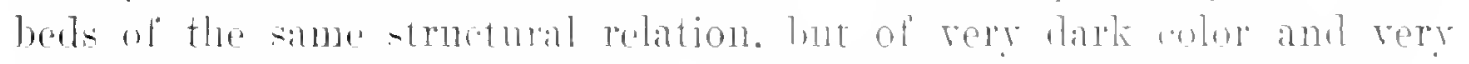
dense habit. Coals to the prinion that the two typu a re not eseentially different in origin. hut that the lighter alowed and lighter woght shales.

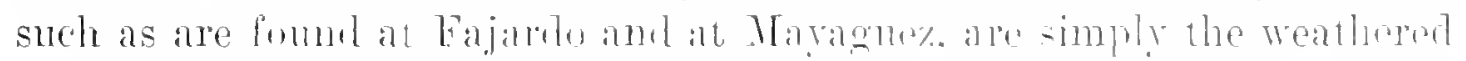
equivalents of darkel ames. It appears from this amparioun that the sluales are normally highly aldarous and that the lime onntent is smp-

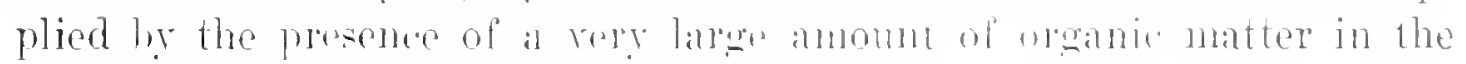
form of foraminifera. In some wass this oromic mater makes np funlly

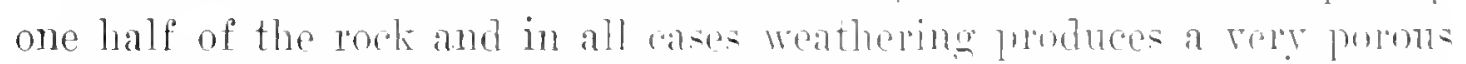
effect that shomld he experted to he identival with the red and yellow

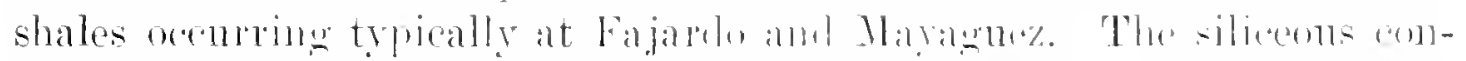

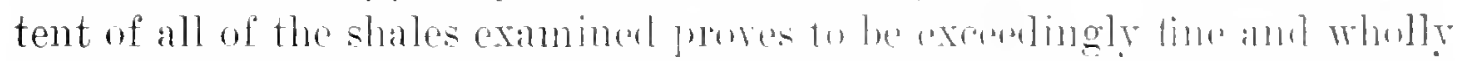
lacking in gramular or pluatzose material such as characterizes most sertimentary shales. It is the jullement of the writer that this material in the shales of l'ortu Rieo, insteal of lexing the optinary disintegration problucts derived from the woathering of urdinary land masses. is in

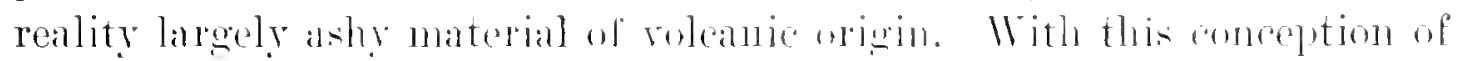
them, it would appear that even the limy shales are therefore close relatives of the ash berls. and it is entimely posible that they do not represent any great difference in history. but rather smewhat diflerent surremeings during acenmulation.

Limestones.-Besiles the shales, there are massive limestone beds of several different trpes.

In most cases the oceurrences are separated by structural complexities that make it nncertain ahont field correlation, but nndonbtedly later field study will comnect some of these and additional paleontologic study will arrange their sucession. The most prominent ncenrrences seen are described helow.

Coamo Tuff-Limestone.- The limestone with the rlosest genetic resemblance to the types already described is represented in a loroad helt passing from south to northwest aeross the upper end of Coamo Reservoj near Coamo Springs and which can be traced in prominent derelopment 


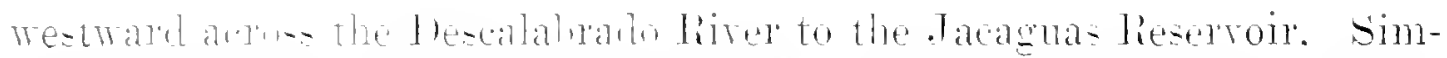

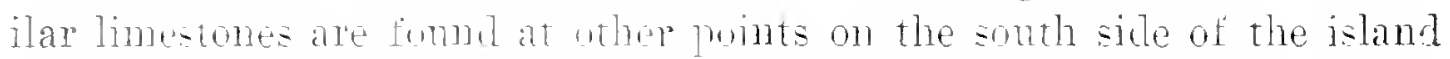
and are judgert to belong to the same member ot the older series. Be-

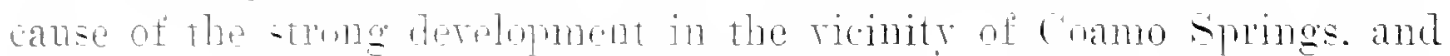

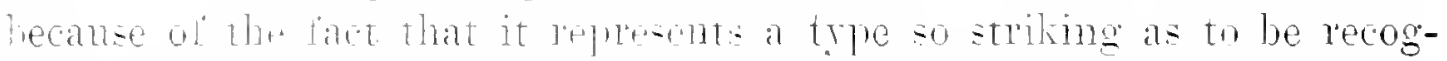

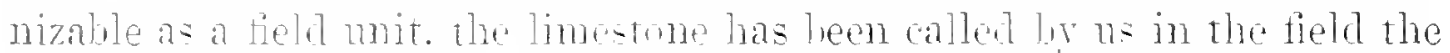

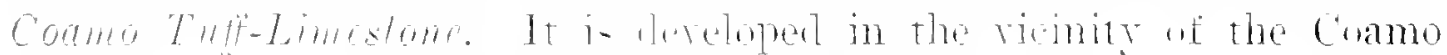

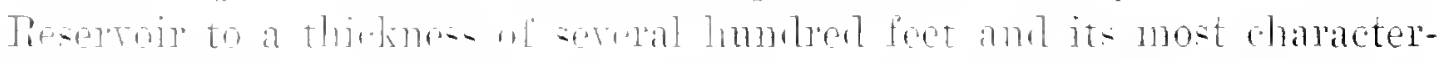

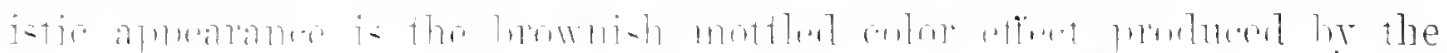

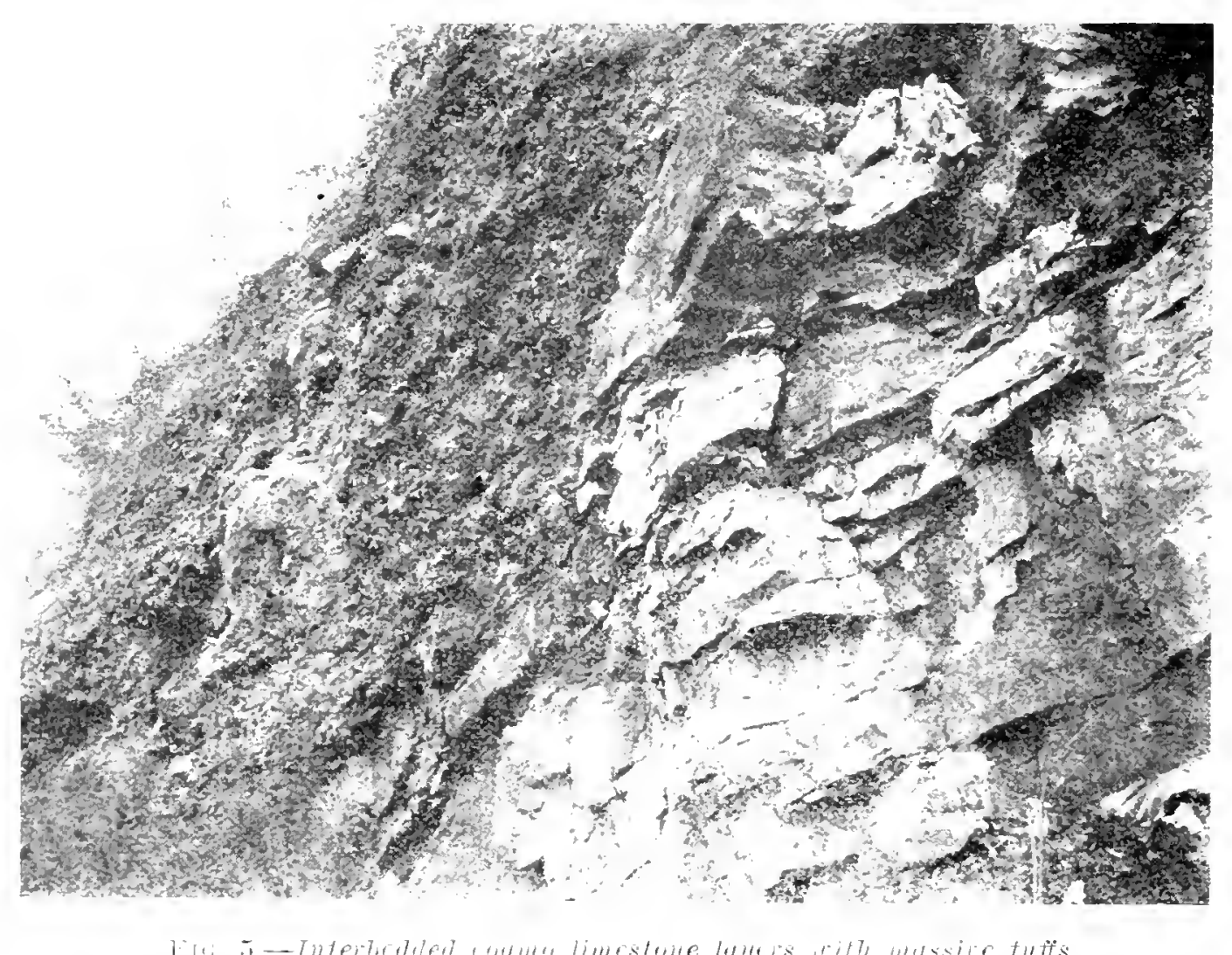

This homation is sem at the military road cresing of the Tescalablado River.

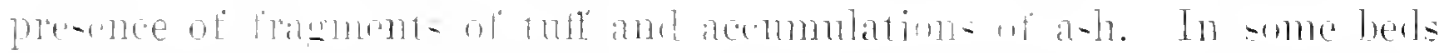

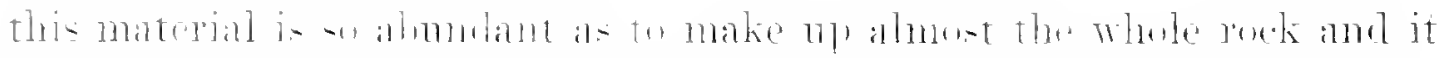

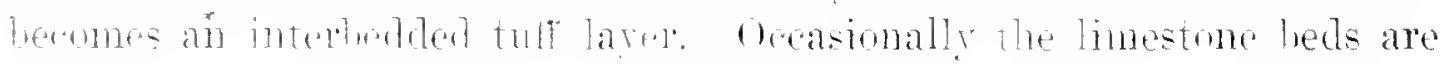

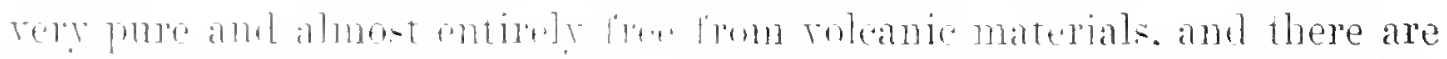

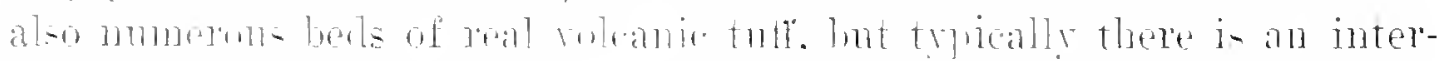

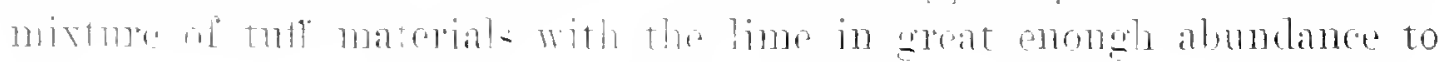

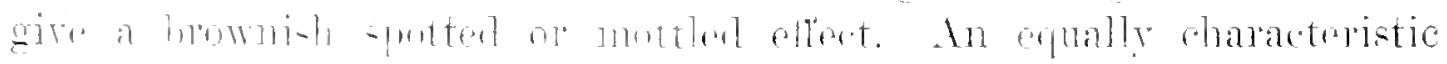

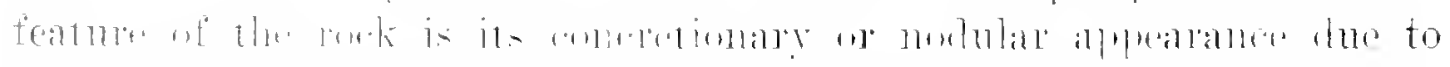

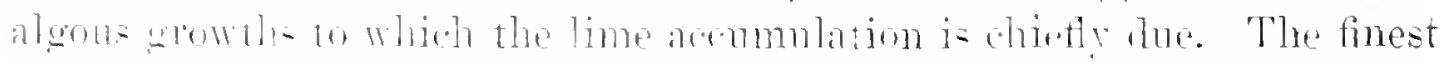

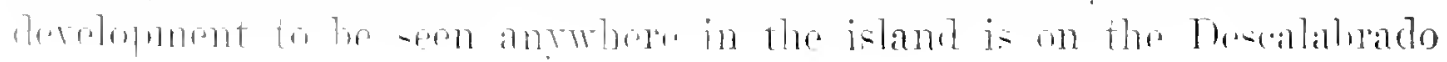




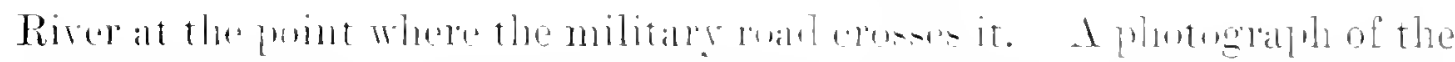

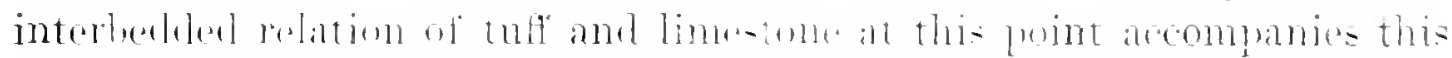

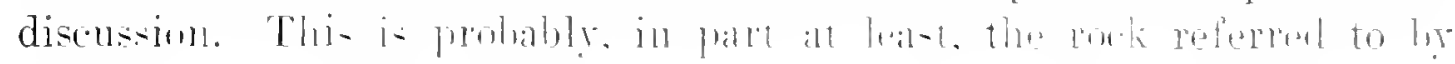

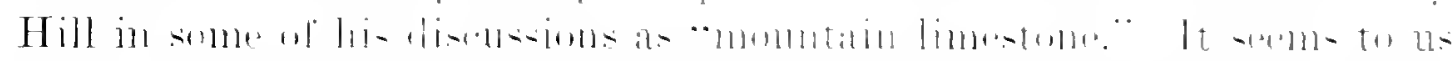

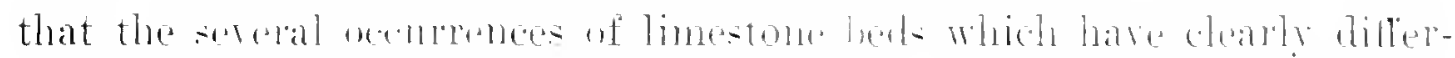

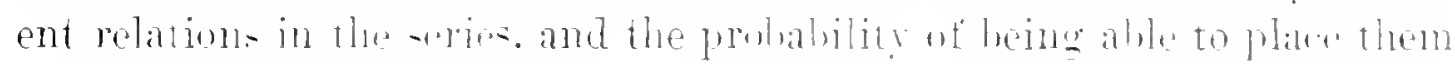

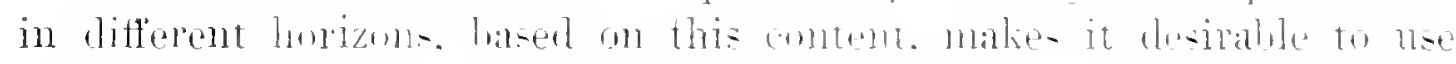

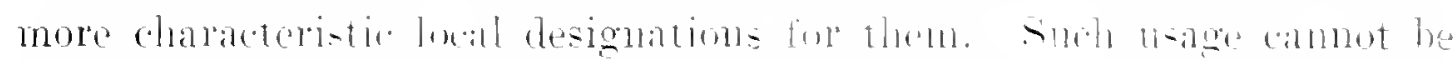

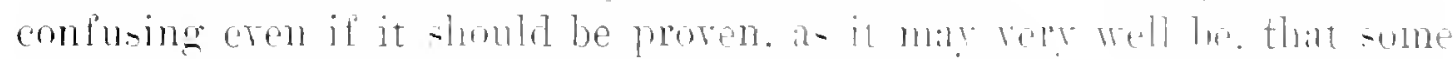

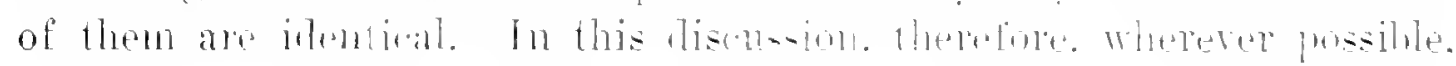

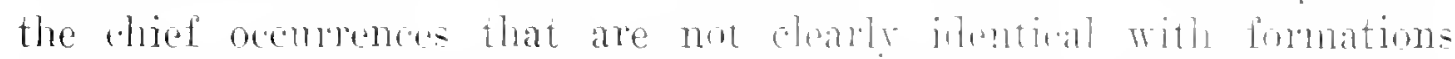

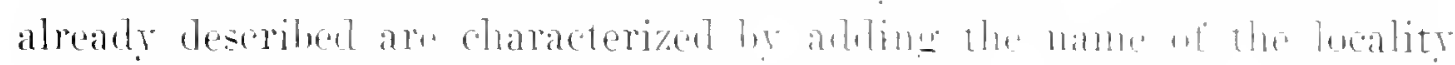

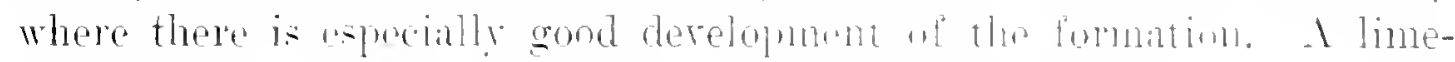

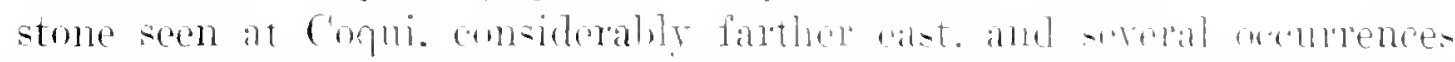
near Yaneo. and others still farther towild the wast. Hate many woints

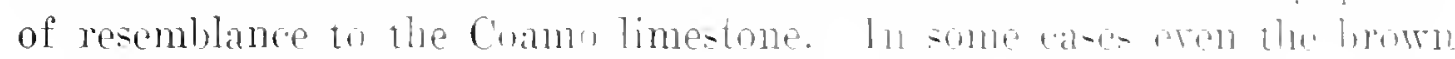

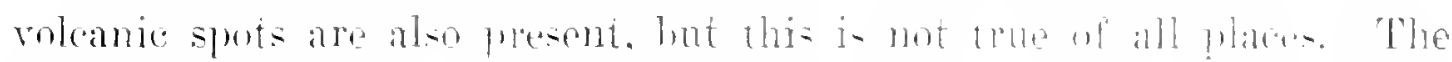

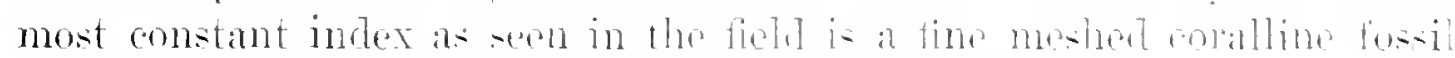

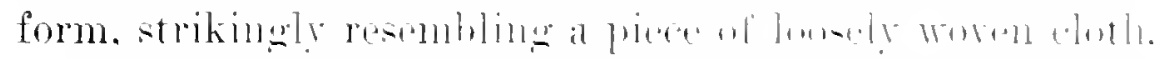

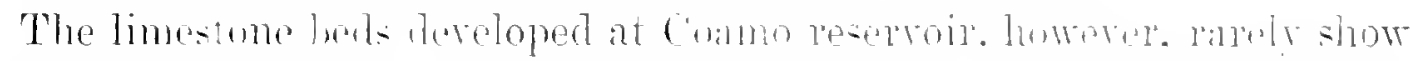

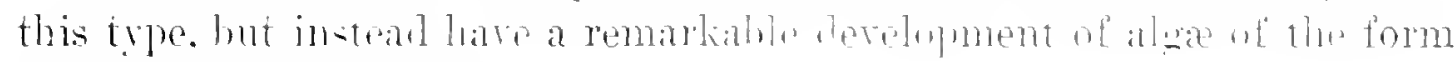
known as I,ithrthamnial.

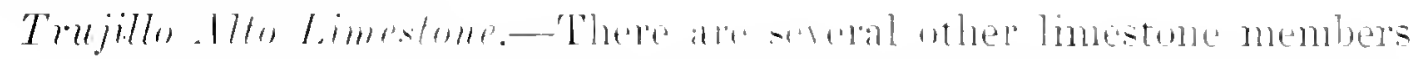
in the older serios. One has been oberent omly on the north side of the island in the vicinity north of Trujillo. Nto and in the ricinity of Loiza. 'This is a rery dense fine bluish lime-tone male up wholly of fine microscopic organic wrowths. In some places it has a rough fragmental structure, hut for the most part the rock is massive and the abmolant urganic content, largely algae, is its mos striking charateristic. Whether it is younger or older than the Coamo limestome has not heen determined, but that it belongs essentially to the same general series is quite certain. On accomnt of its distribution it is conveniently refered to as the Tmjillo Alto limestone reef. This memher probably has a rery moderate thickness and no groat areal distribution. It is affected hy solution developing cares at the Trujillo Alto locality in much the same manner as is the Arecilo formation. but this rock is a moch more compact type and its content and structural relations are quite distinct. It was probably of reef origin also. but is associated intimately with the upper shale members of the older series rather than with the Tertiarr series.

"Shred." Limestone.- Another limestone may be seen at several places on the Arecibo-Ponce road on the south side of the divide from K-13 to 
15-1\%. It has no great thickness, but there are several independent beds. Its mot striking charater is the presence of patches of dark color distributed in a shrerlike way throngh the grayish mass. The rock as a whole is massive, exceelingly compact, of a bluish gray color, and, except for these dark-colored shads. shows no recomizable structure whatever. They contain algæ, howerer, which are expected to determine something more definite about their position in the series, but they are obscure forms, and doubtless considerable work will have to be put on these beds to determine their exilet horizon. They are intimately associated with a series of igneous fragmental beds and a considerable thickness of very red shale or ash beds. Together these alternating limestone and red fragmontal beds make a striking structural succession which was not seen anywhere else. They lie in a position which is not far from the point. where the Coamo limestone belt shonld be expected to cross the PonceArecibo road, but no such structural development lus been noted at any other place. It is, of course, possible that the fine red ash represents the tuths of the regular Coamo formation and the "shrerl" limestone represents a phase of the Coamo not developer elsewhere, but the striking physical difference encourages the making of a distinction, at least for the rimesent.

La Muda Limestone.-A A ather heary development of limestone in the ricinity of La Muda between Rio Piedras and Cagnas las some superficial resemblance to the heds just described from the Arecibo road, but their relationship is not fully determined. The rock is not prominently tufaceous and is not markerl in the same way. It has in places a coarse fragmental structure almost completely obsemred by healing and it is, as usual, attacked by cave derelopment. Some of the cares have collapsed, learing a complex agregate partly made up of igneous material filling the former chambers. A conglomerate bed lies below the limestone and shale at this point and both are cut off abruptly by a large intrusive mass. How these are related to other typical members of the older series is not known, hut it will he possible to trace the lexds to more definite relations. This is probably one of the oldest limestone members in the pre-Tertiary series. It is conveniently referred to as the La Muda Limestone.

In adrition to this there are very mmerons small or thin local developments of limestone layers distributed through the shale heds at varions points. Thece are taken to he, in most ases, simply somewhat more heavily develomed limy layers of the same origin as the rest of the foraminiferal and ahy shales; but the nature of their origin shows that it is reasonalile to rxpert a herelopment of calcareons content suffieient to make thoun more of a limestone than a shale. 
"Mountuin Limestome."-In sme localities, snch as that near Barranquitas, and probalbly at other points along the same divike, the shaly beds heenne rery alkatents. as has been pointed on hy Mr. Mill. 'These were referped to $\mathrm{h}$ him as limestmes and are pohably inchoded in his "nummtain limmenome" and estimated that the thickness of such heds ammontol to buly a thmant leet. The prominence of the shaly struc-

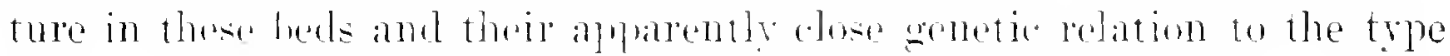

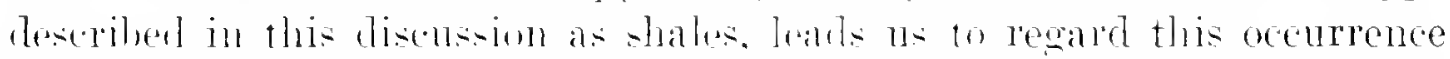

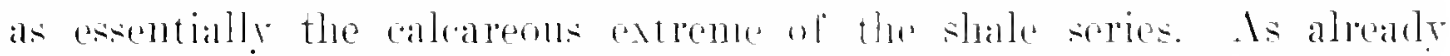

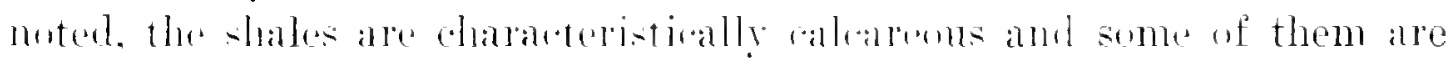
predominantly so.

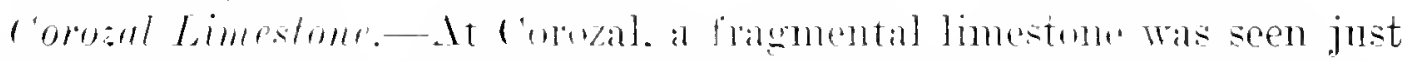

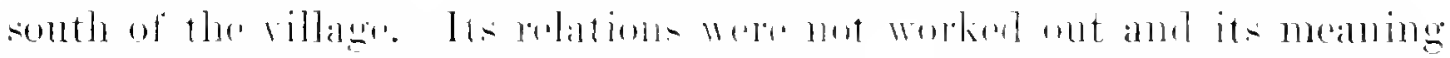

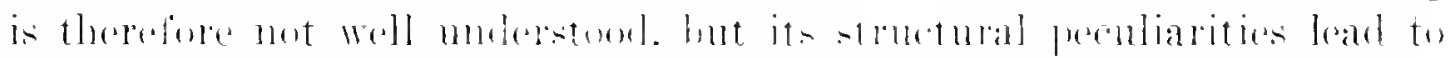

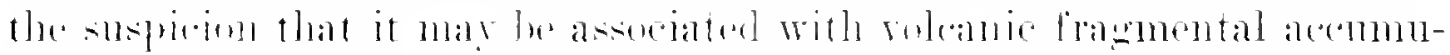

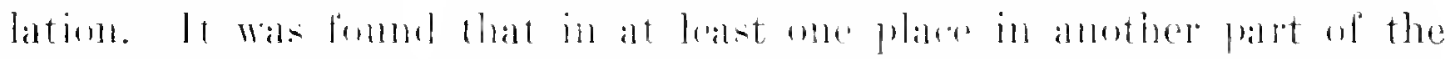

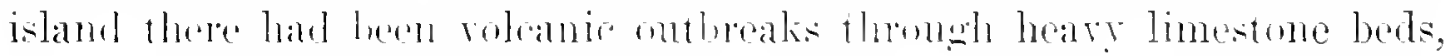
and it is ovident that lagmental material from sheh artirity might

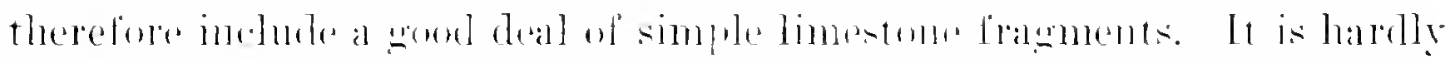

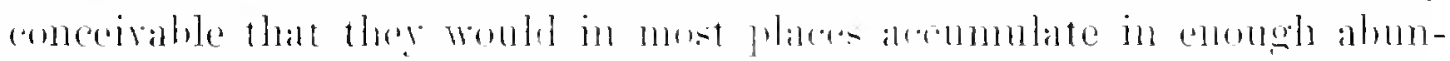

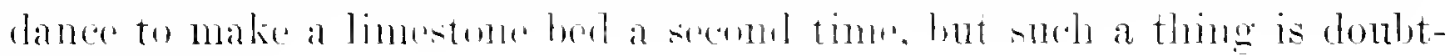
less posible.

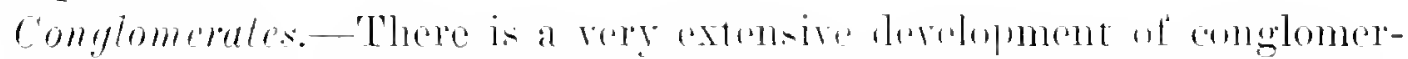
ate oceuring in a lent whose weneral treml sems to be from sontheast

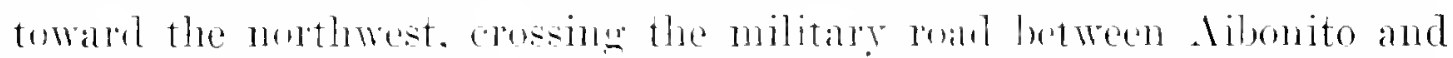

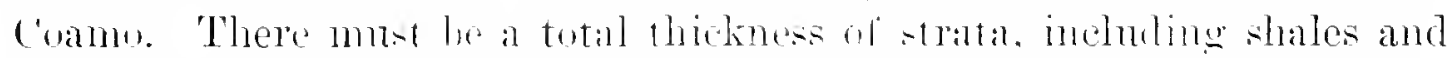
interbededed tortis with cocasional small limestme. of perhaps sereral thousand lect. In all parts of the formation where conglomerate is dereloped. the peblules represent the same kinds of rocks as wore encumtered in the tuffs and intrusive masses. Actual representatives of previously solidified bedded material or immuted ash or shales are very rare, but in one case at least a pebble was obsered that was jurged to ropresent a frament from an older silicified tuff. As a matter of fact, the materials are practically all of simple igneous character and the matrix in most parts of the formation is very abundant, or even predominant, the particles of which are of the same igneous material. The distribution of matcrial and the range of composition leads one to believe that this conglomerate represents a special state or condition whereby materials of essentially tufaceous origin were. immediately alter their volcanic eruption, worn, rounded, somewhat assorted and bedded and mixed with related material. At the point eximined, there was no satisfactory 


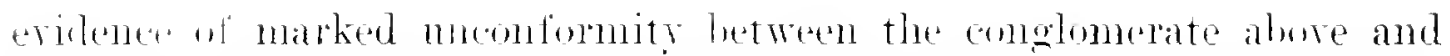

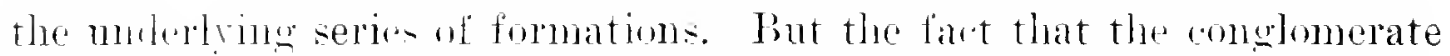
beds. which bollow to great thickness are prevalingly of simpler structural habit. as complated with the calcarems shates ash and tuff series immediately below. -ngoests that there may be a hreak here of larger

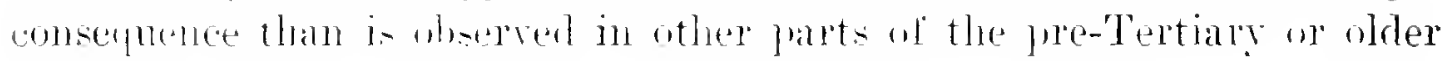
series.

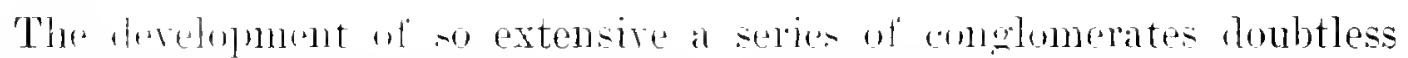

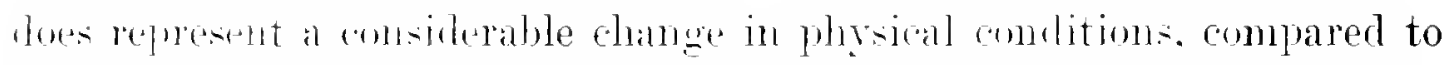
these antrolling simples deposits which preceded and follower them, and it is posible that it may be fomd nobul in separating the complex series bl ohler mixed bethere rocks and tutts into an older and a romger dirision by using this comglomerate as a dividing nember. This is supported to sme extent ly the orenrence ot a conglomerate of similar character but of rery mueh less extent on the north side of the ishurl. sereral miles south of Baymon, and also one uf apparently less prominence near La Mula. If adritimal field work shomld show that the conglomerate belt combl he traced from one side of the island to the other. it seems to me that it would bo atirely practicable to make this division.

The englomerate is invarded hy inneons intrusive material in much the same mamner as is aberrol in the other rock brmations. hut the massive luabit of the rock an a whole leads to a predominanot of transrerse dikelike mases rather than the simpler looking sills. At one point in particular. lwwerer, near K-86 on the military road between libonito and Coamo. the comglomerate has been invaded by a manma that must have been Huil anomb to ponetrate the porous matrix surmuling the conglomerate phbles where it now exhibits a crystalline habit. This injected matrix is essentially a coarse diorite proprery in composition, through which the peblus are distributed in the mamer that they seem to have han in the uriginal rock. so that there are still obscure traces of bedding structure. There are additional petrographic peculiarities in this ruck that will be deseribed under a different heading. 'This tendency of the dioritic magna to penctrate and incorporate fragmental matters was noter in screral other places. It was most strikingly exhibited in certain intrusive members cutting through tuffs and shales. In some of these cases there is so great a quantity of fragmental matter as to wholly obscure the true nature of the rock nnless one can see the structural relations. In the case of the conglonerate, however, the crystalline habit of the matrix is a striking feature and it is very evident that it is wholly different from the regular connlomerate habit. 


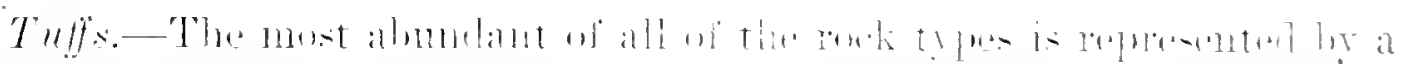

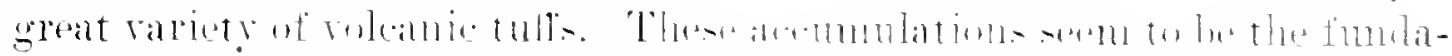

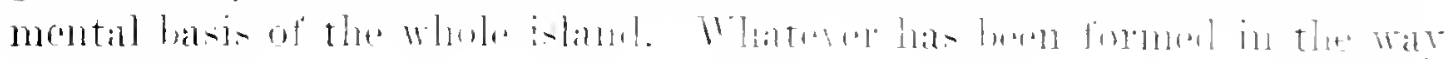

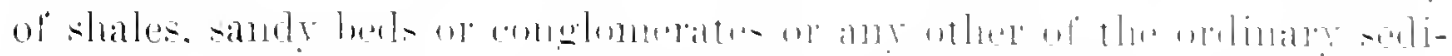

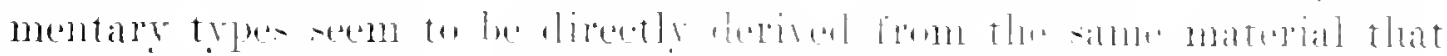

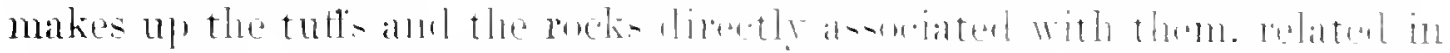

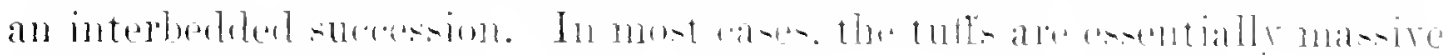

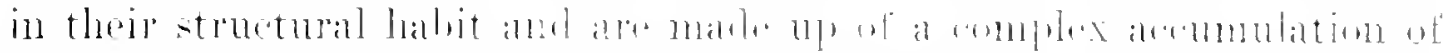

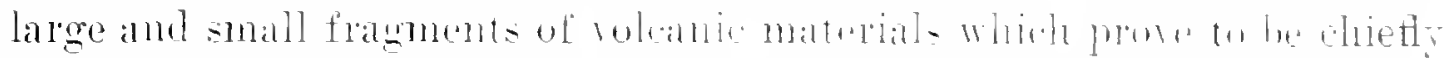

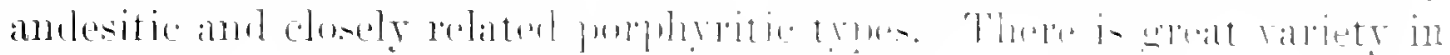

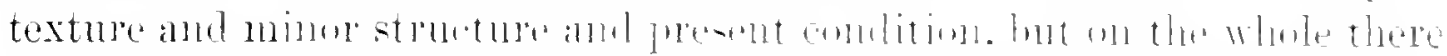

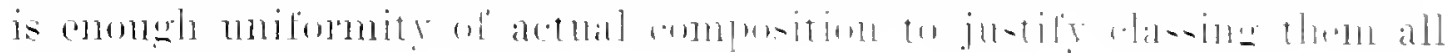
as andesitic tulls.

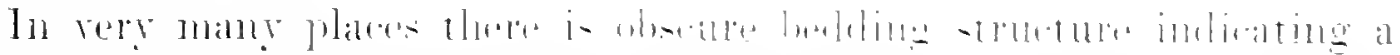

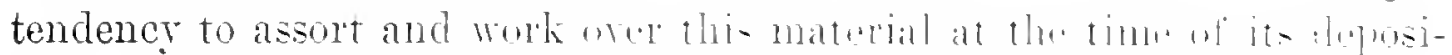

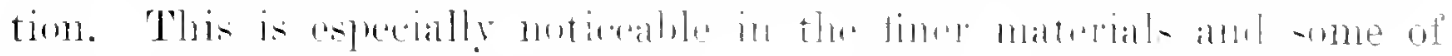

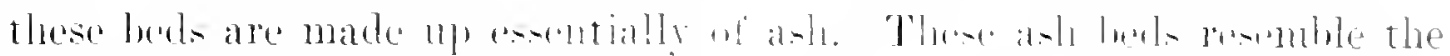

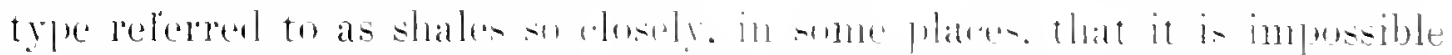

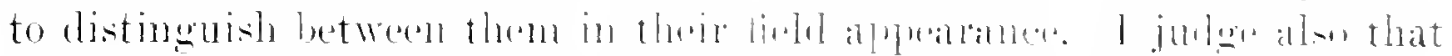

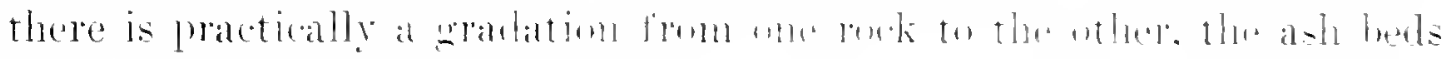

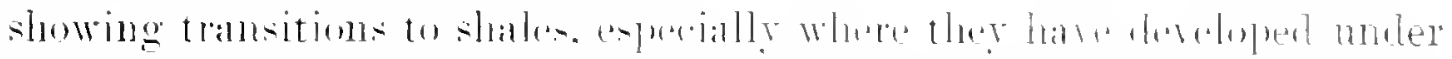

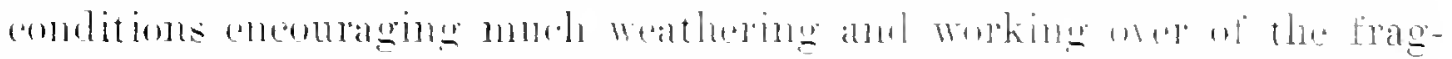

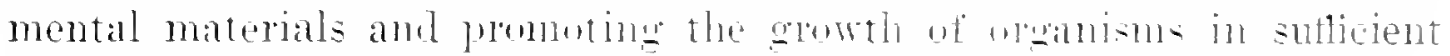
amount to make the accumblime hods somewlat alcareous in composition.

Tutf: and ashes are well known to be especially lialle to attack by alteration and to the ordinary changes that molify roks. It - happens. therefore, that many of these representatives are completely momified and

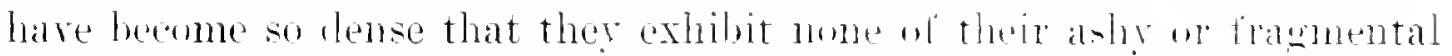
structure without micoscopic examination. In this entulition they are nsually also exceedingly hard and as resistent to drometion as the haldest crystalline rock. The largest levelopment of masive almost struetureless tuffs which were seen occupy the sierra te cilyey between Guayama and Cayey and also the range along the military ruan toward Aibonito; but there are extensire wourrences in many other sections. Some of the most prominently developerl berliterl tutts amb ash beds were seen on the north flank of El Innque along the sabana lires and on the north side of the divide below Comerjo. and also along the Ponce-trecibo Road both near the summit of the range and farther to the north midway between Arecibo and Utuado.

From what was seen of this tree of rock. it was not possible to form a 
Aefinite conchsion concening the ase represented except by their relation to cortain interberlded shales and limestones. It appears that the underlying ulder portions ol the series of tulls and ash berls have comparatively little of snch interbeded calcareons material and have everywhere heen modified or altered or metamorphosed to a greater degree than berlis that lie highes in theseries. Thut lepond this there is little to judge

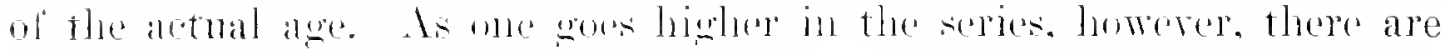
orasional frominent limestrue menthers with which tufts are intimately

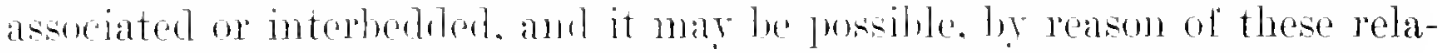

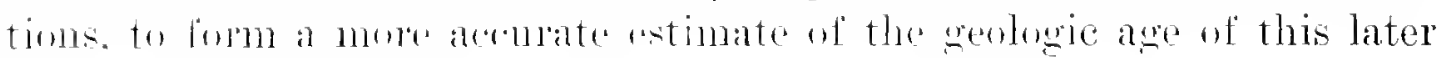
portine wit the series.

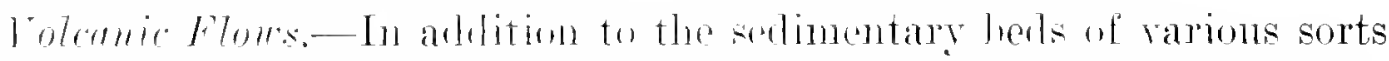
and the perated tufls. there are at areasional plates cridences of roleanie

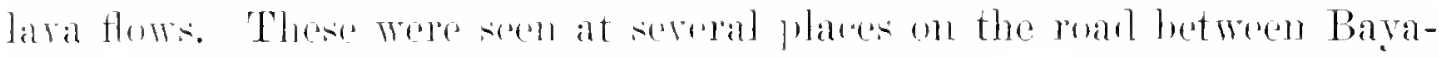
mon and Barranguitas. They are amyodaloidal in present habit and

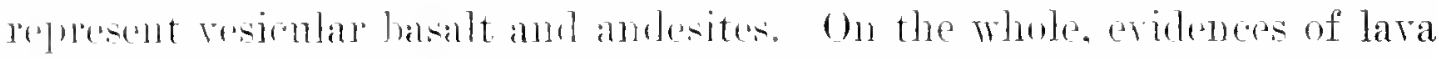
Hows on a large sale are wanting. This kimb of prodnet seoms to have

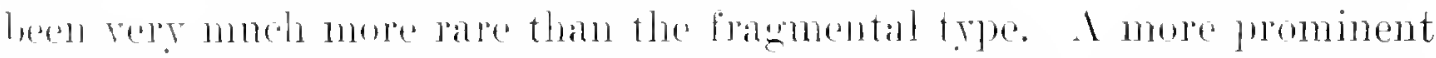

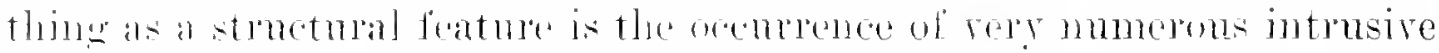
borlies.

Intrusiess-The intrusive masses in Poto Rico oceur in all parts of the island and in all of the formations except the Arecilu and the over-

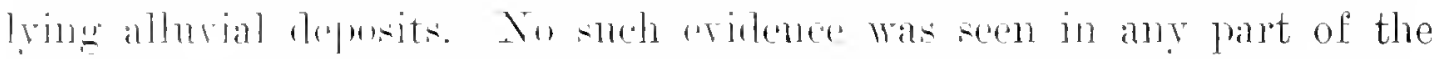

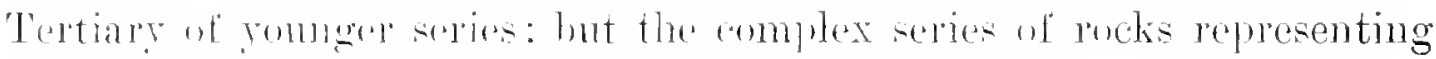

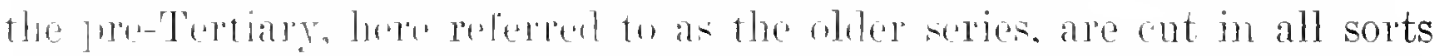
of ways by both large and small inturive masces. The smaller intrusives

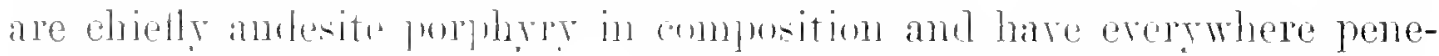

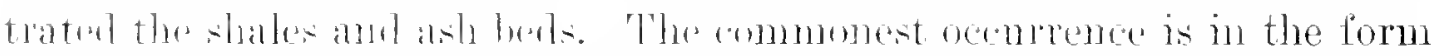

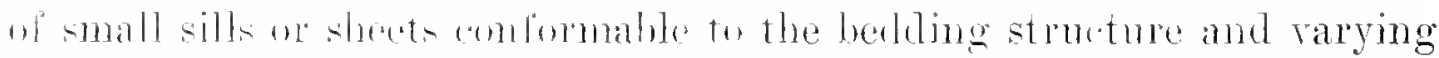
in thicknese lown only a lew incles to many feet. These sills are so perfeet in form. have so little disturher or molified the adjacent beds, and

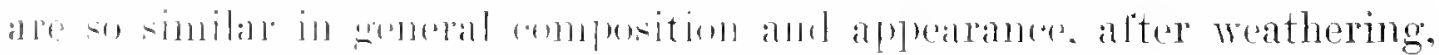
to the astociated sedimentary hols. that it is quite impossible to deter-

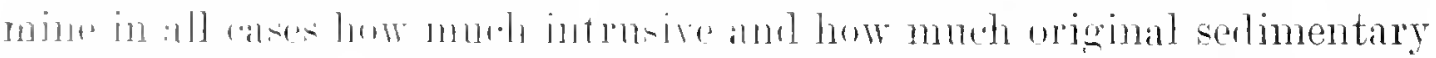

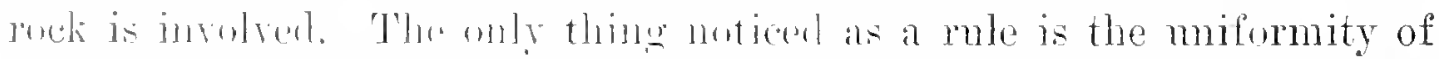
petrograjhic struture that serms to be characteristic of the intrusive as companm with the aswerated beds. The simplest ocenrences of sills of this kiml. which at the same time show their ignems intrusive chander, Wor san Jul Fajarlo. near Rio Piedras and in the vicinity of Comerio.

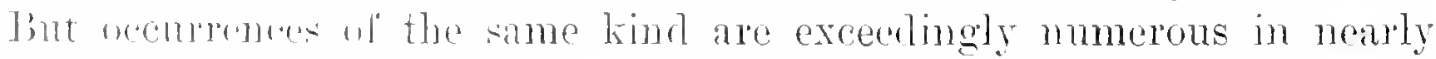

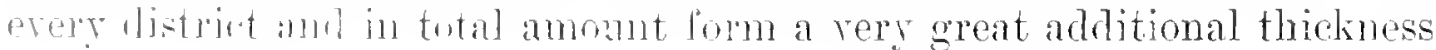


to the berhled rocks. shales. anh berk ete. with which ther are assuciated. In some ases thew invaling manmas have incorporater preat quantities of fragmental matter. wiring the rock in its present ondition a very strikingly framental aprealance. This habit associated with it s perfectly apparent intrusive redation makes a very mus-ual combination in the field. In many places there are induled blocks of immediately arja-

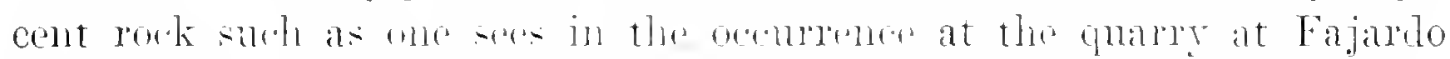

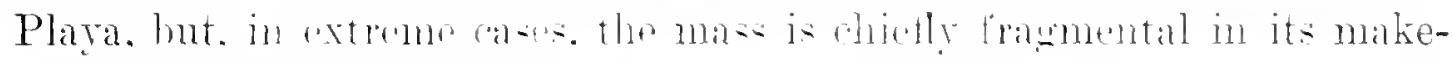

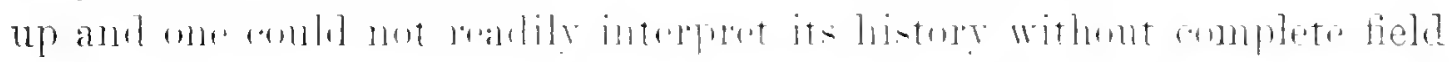

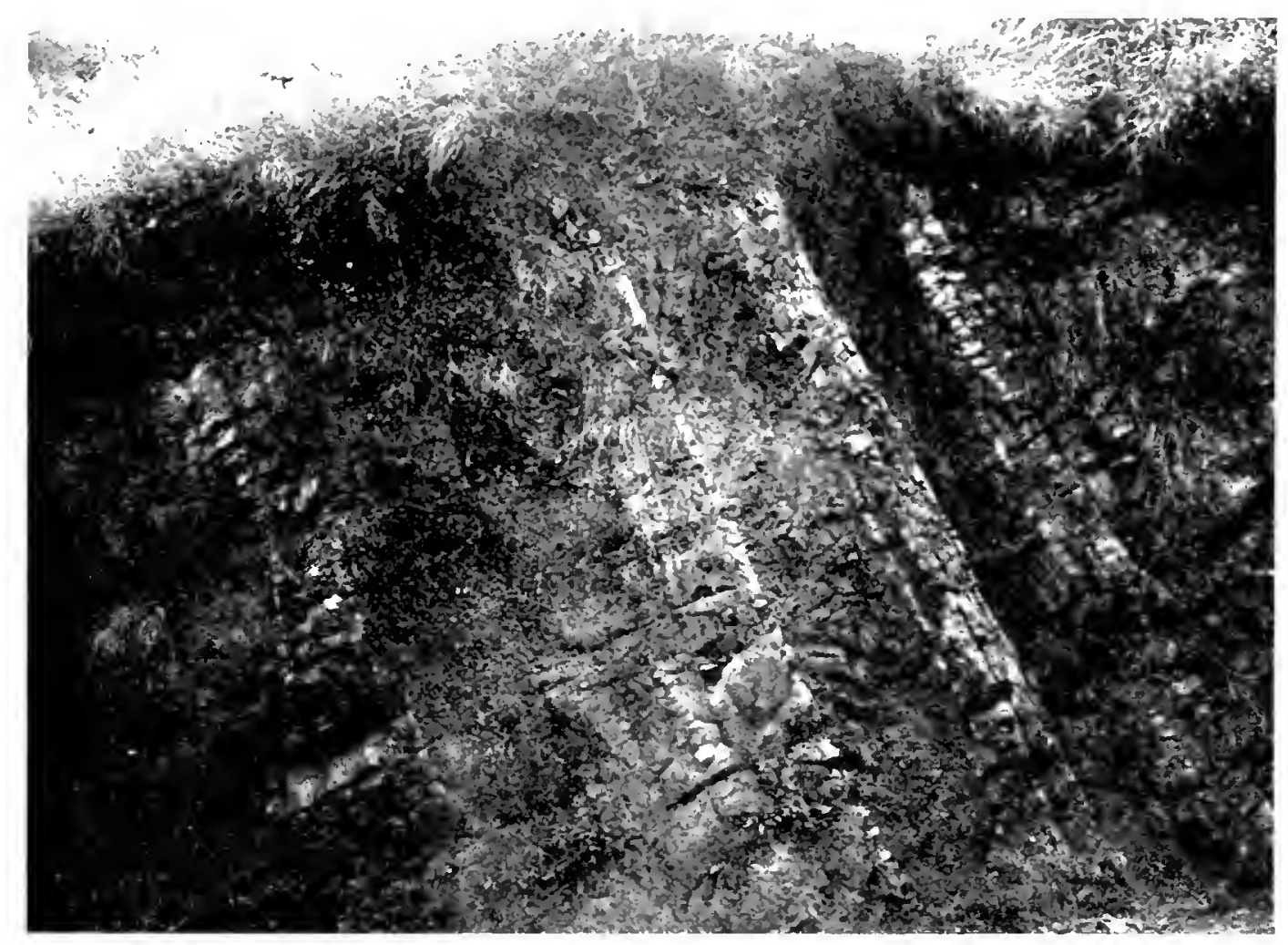

Fri. R.-Diorile porphtry sills

These sills are intruded helween lavers of callateons shales and ash beds on the ruad

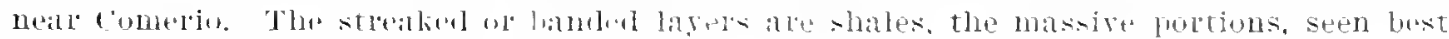
at the left side of the mint, are sills. A tankgrosive lelation can be seen betwen the two layers at the extreme left.

determination of its relations. Such ocenrences may be seen in the vicinity of Guayama un the rual abont a mile east of that place, and als. a short distance sontle of Rio Piedras.

Few of these intrusive masses slow anytling but a rather miform medium grain texture and larger ones have the arerage appearance of a rather fine or medim grain diorite. 'The granular appealance, however. is probably deceptive, dne to the way the rock disintegrates, for thin sections made from many typical intrusire repesentatives are nearly all plainly porphyritic in textmue. 


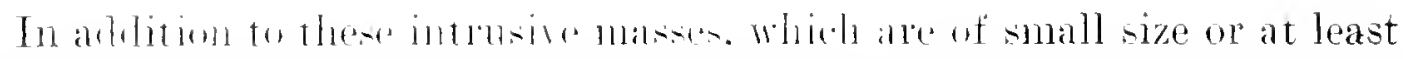

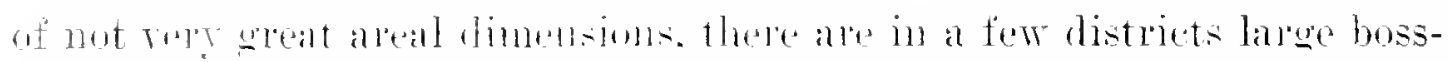

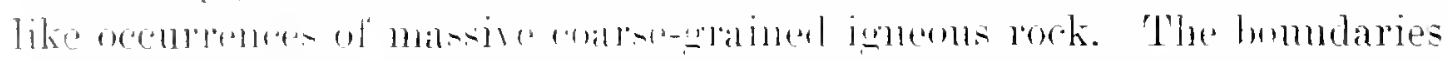

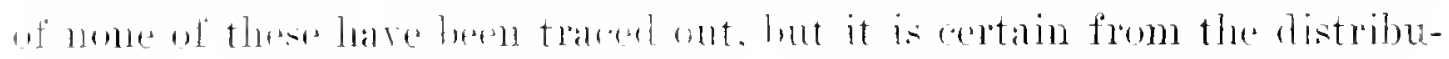

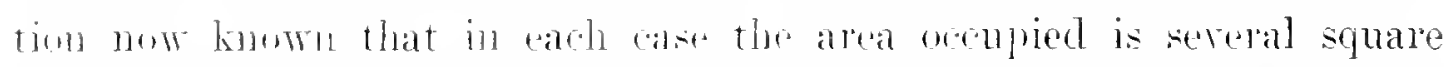
miles in extent. The mont pomiment one of this type of intrusive mass is that seon in the soltheast portion of the istand. inchuding the district

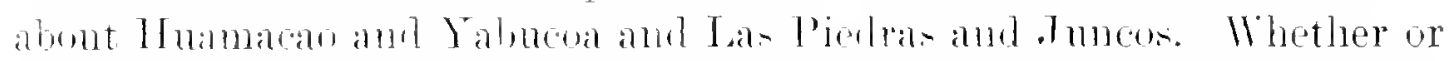

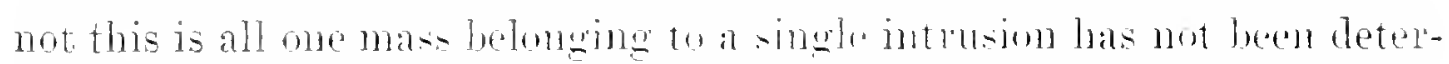
mined. The varioty of ammustion som in the different smoples taken at ilferent prints is consistent with the lowence of nore than one intrusive unit; but it is also possible and yuite as likely that the raliety obsered is wholly due to magmatic nillenentiation. The sontherly portion of this mass. especially that near lahmood. is repesented by a rerr coarse. fery quartzose and almust pegmatitic granite. Farther to the north, in the ricinity of Las Piedras and Jumces, thr ruek has the appeance of a

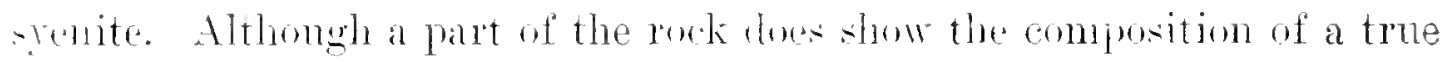
srenite. by far the greater number of speimens collected on this expedition show the presence of quartz in sufficient amonnt to make the rock a granite. It would appear, therefore, that this occurence in the sonthtast pution of the island is essentially a granite mass and that it is of unusually la rege size, reaching practically from the coast at Mamabo to Canmas. The listance across this man is. therelore, not lese than about 1: miles morth and somth. In all probibility it is not of quite so great an extent rast and west. but these boundaries ane molnown.

One whe large intrusive mass was oberved in the west central part of the islank. in the vicinity of Jayuya and Ctuado. In general appearance and texture this rock, in the average onterop, does not differ much from

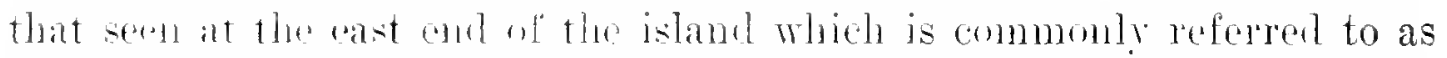
symite. In thicucourenow. howerer. such specimens as have been examind with the ald of the mionosme. show the presence of quartz in most cases in sufficient amonut to make the rock of granite composition. In this case. an in that relirred above. there are comsilepable differences of composition - lum l,y the roxk which seem to be a part of the same mass. Specinmo fomml, low example, near Arjuntas have the compositional charachristics of diorite. Whereas a specimen taken near the margin of

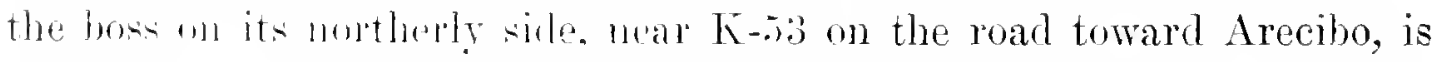
a syenite. At certain other points near Utuado, the rock is a granite purphy?.

The best idea of the variety of composition and textural quality represented by all kinds of intrusives in the island can be gathered from an 


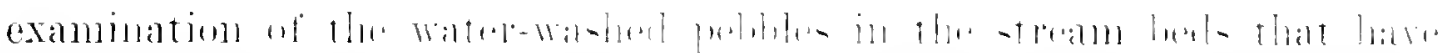

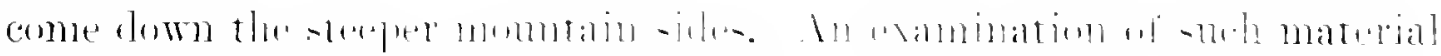

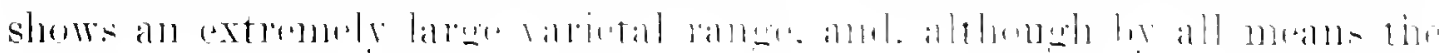

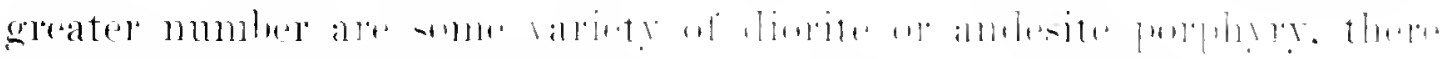

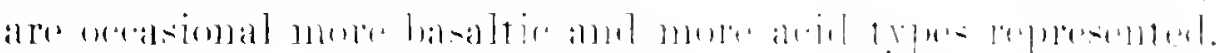

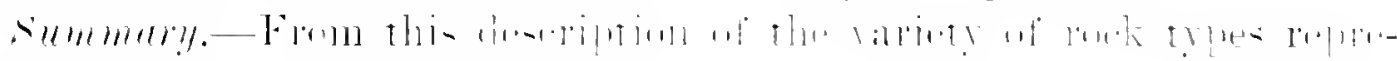

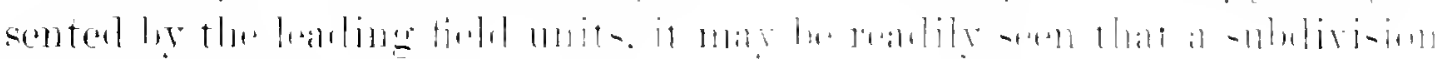

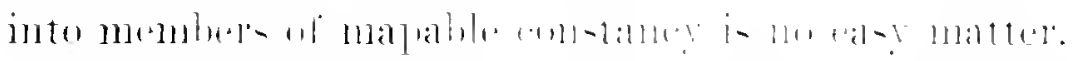

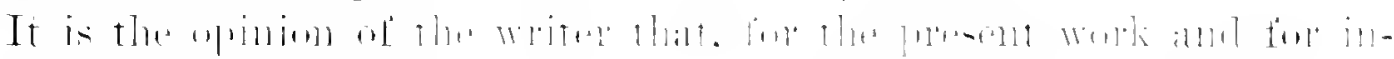

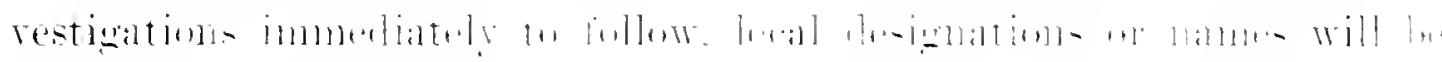

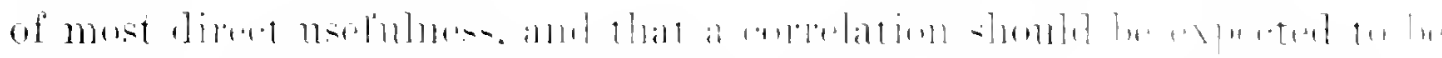

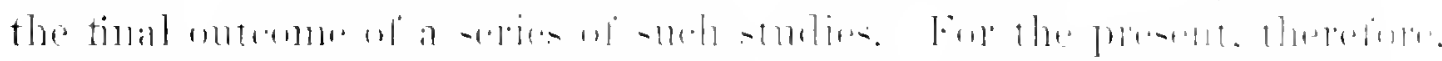

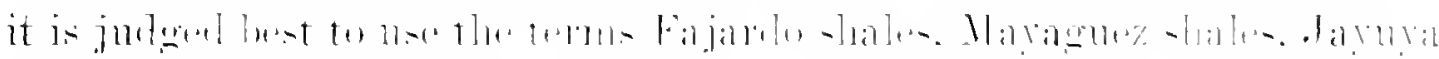

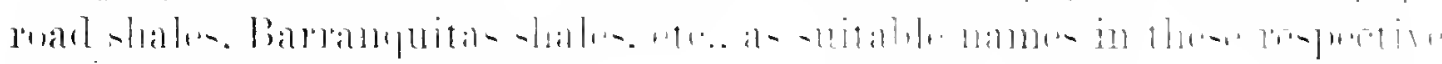

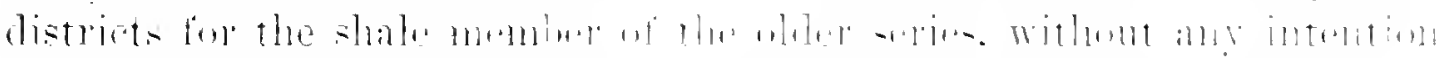

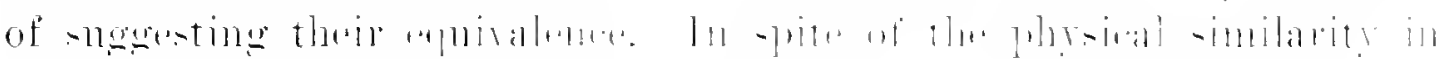

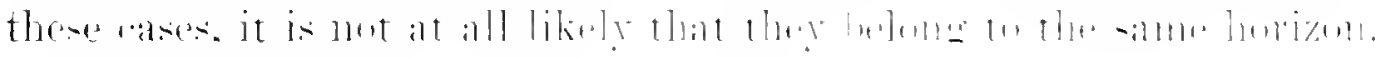

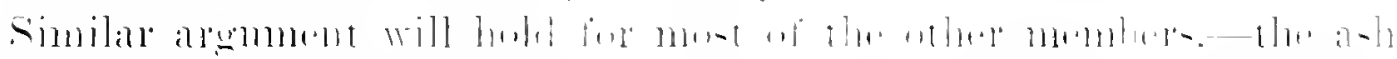

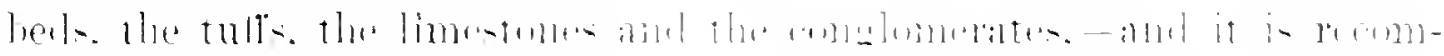

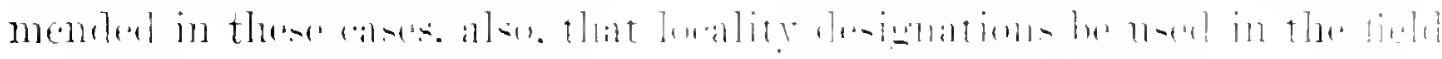

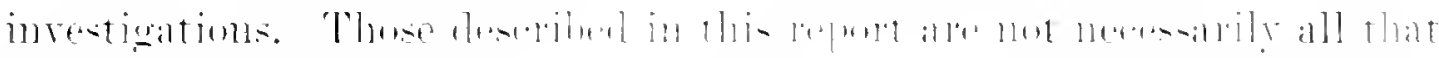

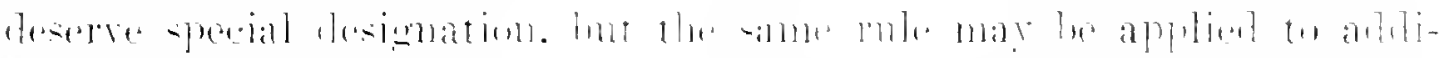

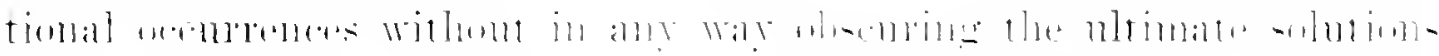

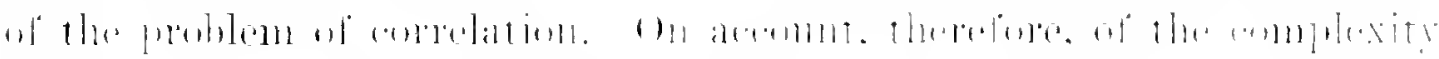

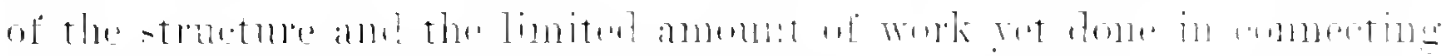

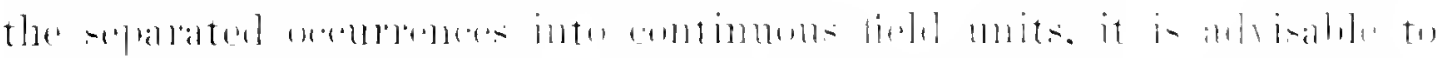

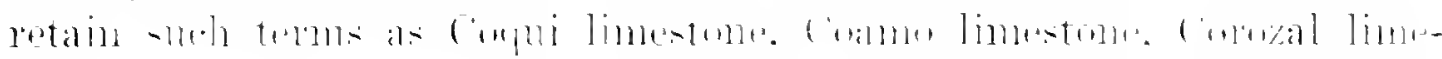

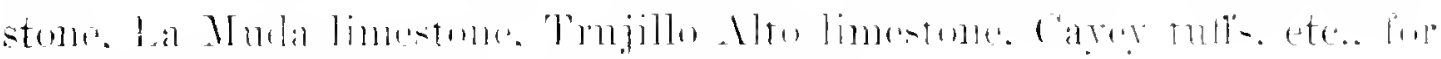

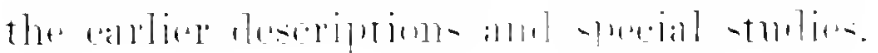

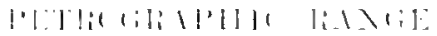

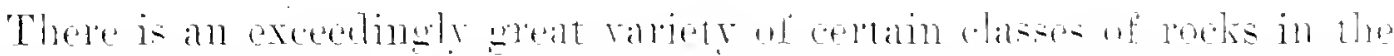
Island of Porto Rico. Thon mon pombently dereleped and showing

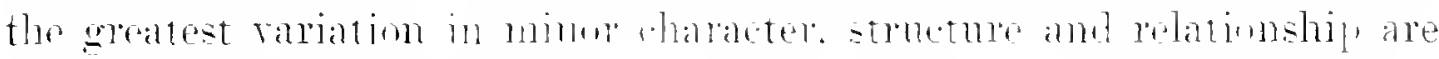

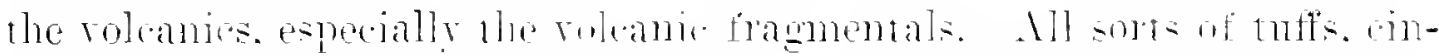

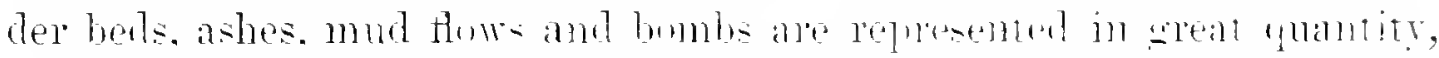
in rery wite listribution and in all stage of alteration and indmation.

Observations mate on thomsands of acempences of this character of materials learls to the conchsion that most of it is essentially of andesitic composition. Althongh there is an ocosional fragment of ejther more

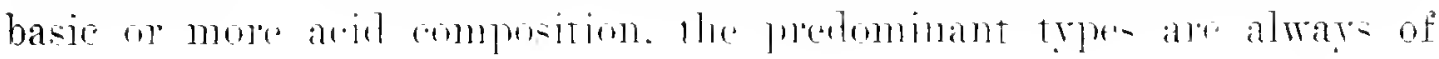


andesitic makemp. The present condition of these roks, representing as they do nearly alt stages letween tres material and either a thoroughly weathered or considerably metimorphosen (onclition, is a more interesting stuly than their primary comprition. Sume of the most dense and resiotant roks in the whole island are these older metamorphosed tuffs and ashes.

Next in point of almulance is the gromp of crestalline igneous rocks.

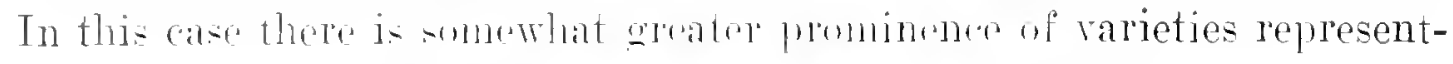

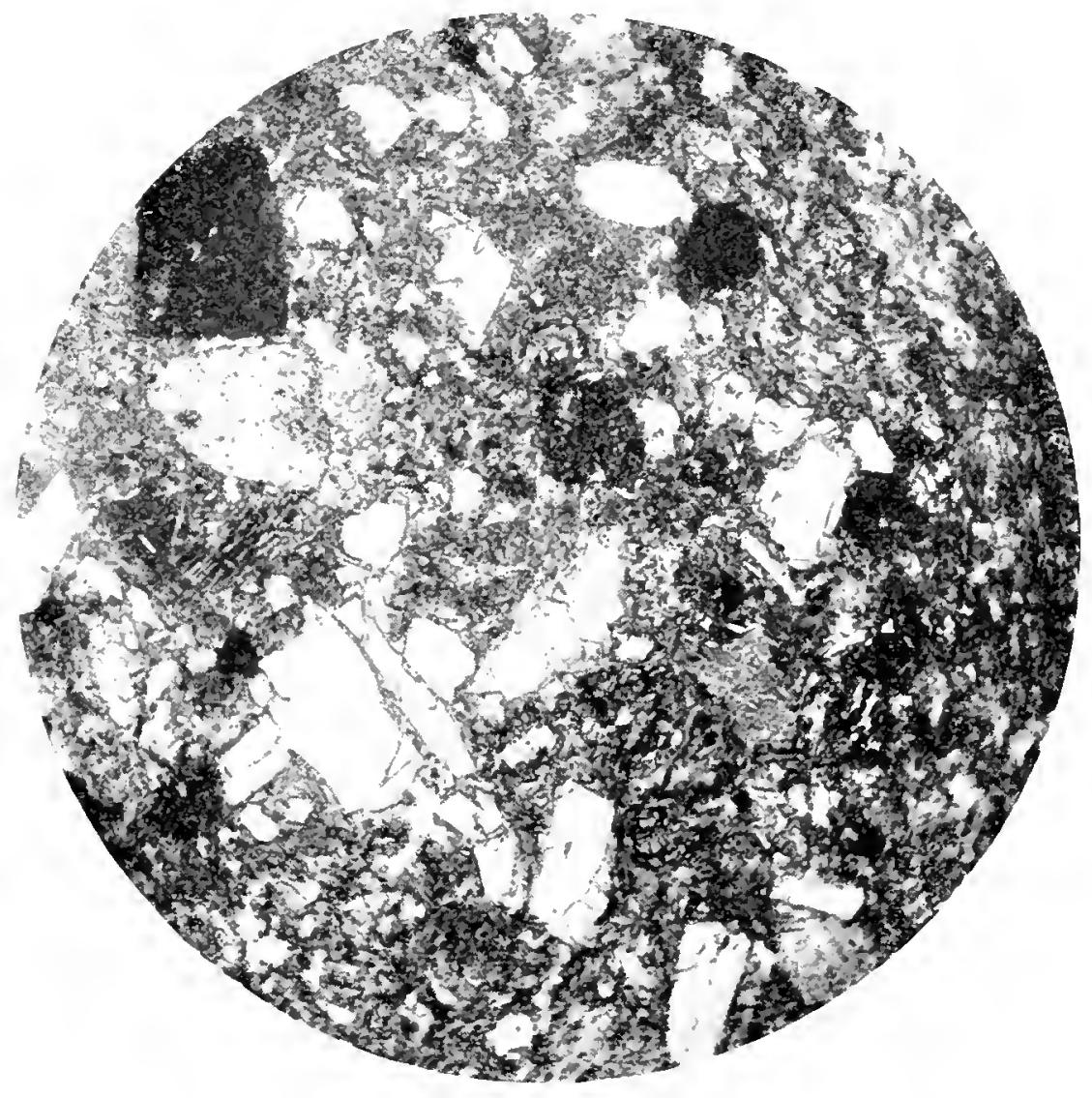

F1G. T.-Photomicogranh of a typical thoronghly indurated andesitic ash, magnifieation $\therefore$ diameters

A rock of this type appears in the field as a dark-greenish hard resistant obscurely

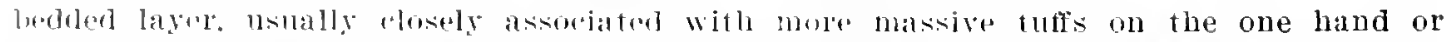
more strongly bedrom slabes on the other. The real wrains are mineral fragments; the more complex grains ale liamouls of lava, cinders. glass, etc., all thoroughly bound inter a complex agrergalte.

ing the acid and bisice ends ol the (e) rocks of the andesite-dionite fimily ale liy all means the most numerous and most widely distributed. The ghater mumber of occurrences are regerented by mombers uf this lamily helomeing to intrusives that would

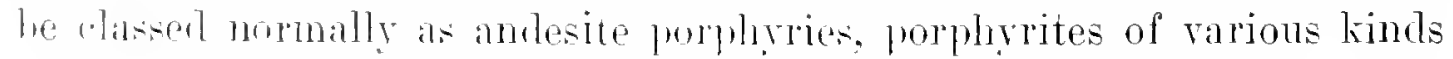

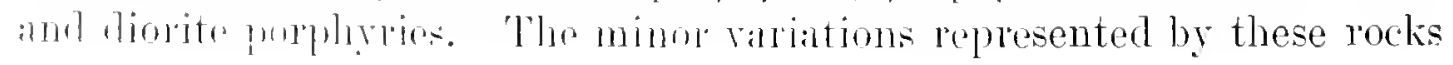




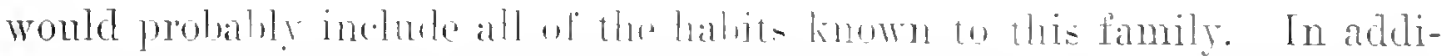
tion to the porphyrjes of this family anp wition. there are less common occurrences of lelsite, quartz porpluy. wante prohry and basalt

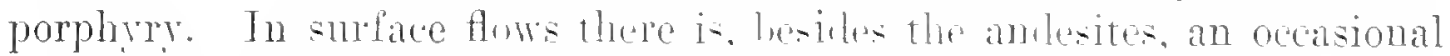
amygdaloidal hasalt, but so far as ulserved there wis no molite or other very acid surface type. Among the masive larger intrusives, the commonest and most abundant trpe is a granite porphyry or granite rarring

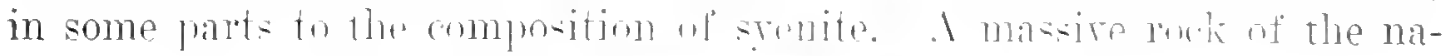

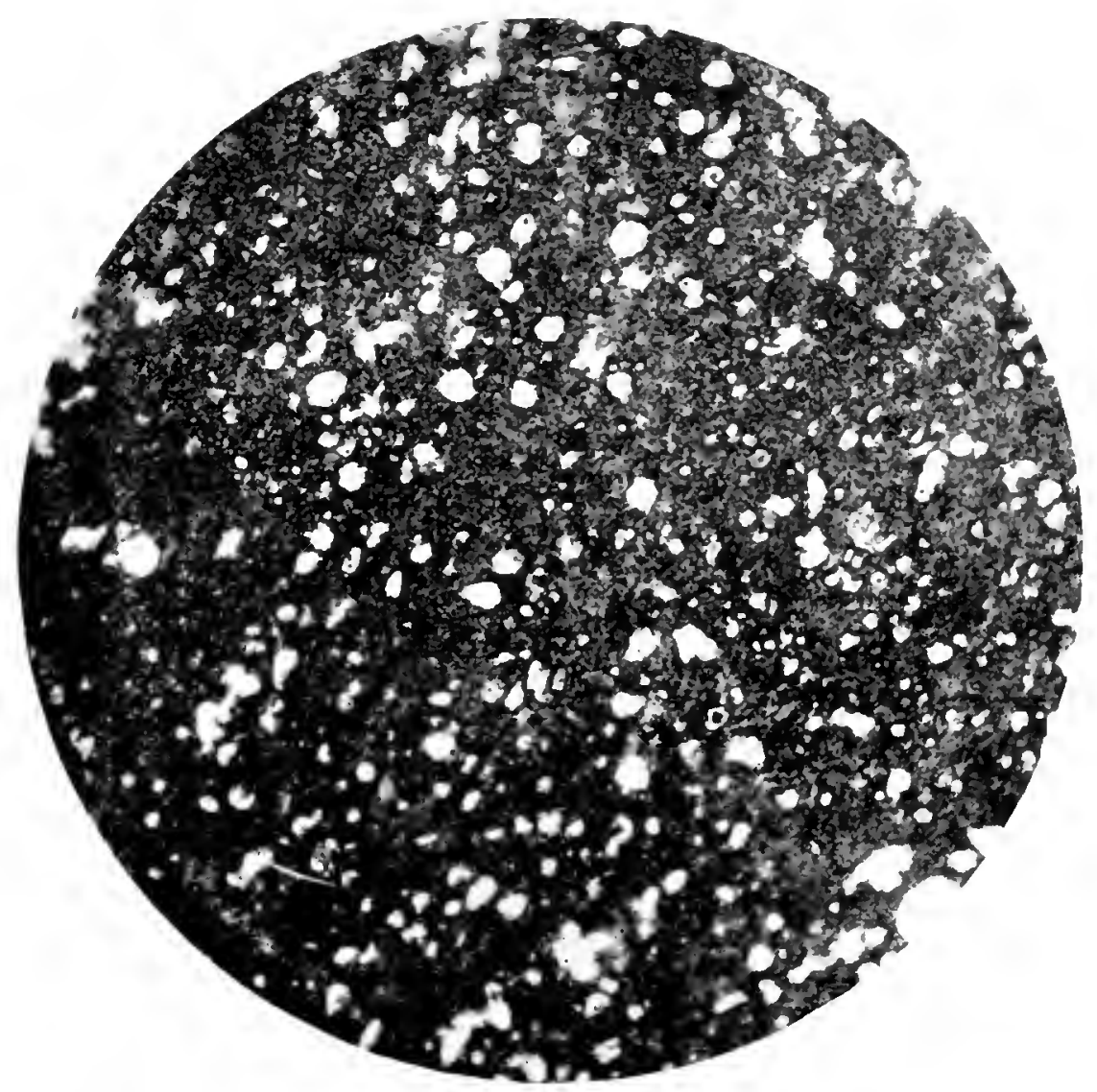

Fig. S.-Photomicrograph of a typical ucathered shule from Fajardo Playa, magnification as diumeters

The dark field is made up of an cxtremely fine aggregate of earthy materials. The white circular and irregular spots are entirely empty and constitute the porosity of the rock. The circular forms of these roids suggest that they represent former calcareous content in the form of foraminifera, now completely remover by weathering.

ture of a diorite is also represented, as is a very coarse rock of the nature of a giant granite. How these are relited, luow many intermediate varieties there may be and whether this rariation represents magmatic differentiation within a single mass or instead different mits of intrusion, has not ret been determined in enough detail to make a positive. statement. But in at least two cases where these large masses were seen, 
the Hast exanination given to them leat to the beliel that differentiation thet- can be tracent.

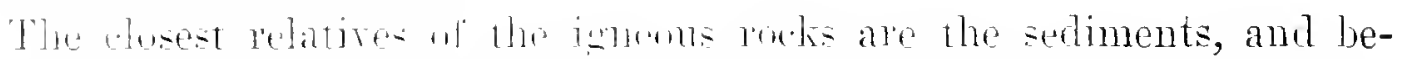

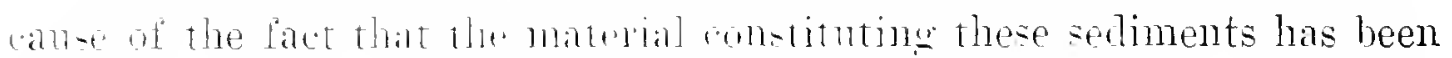

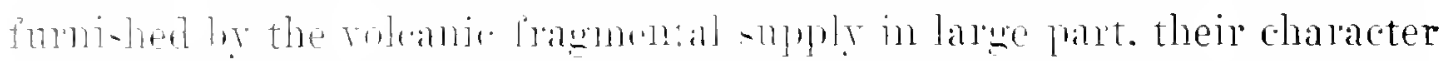

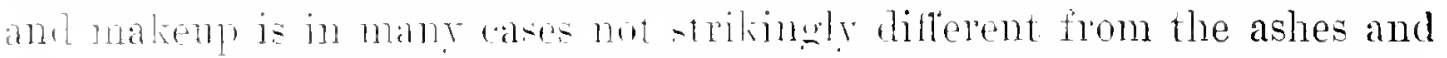

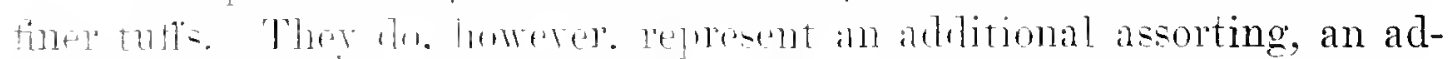

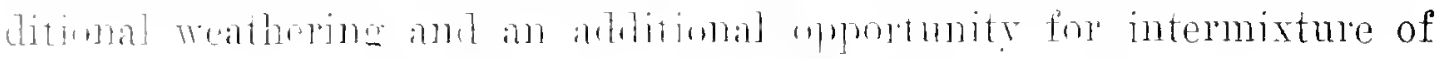

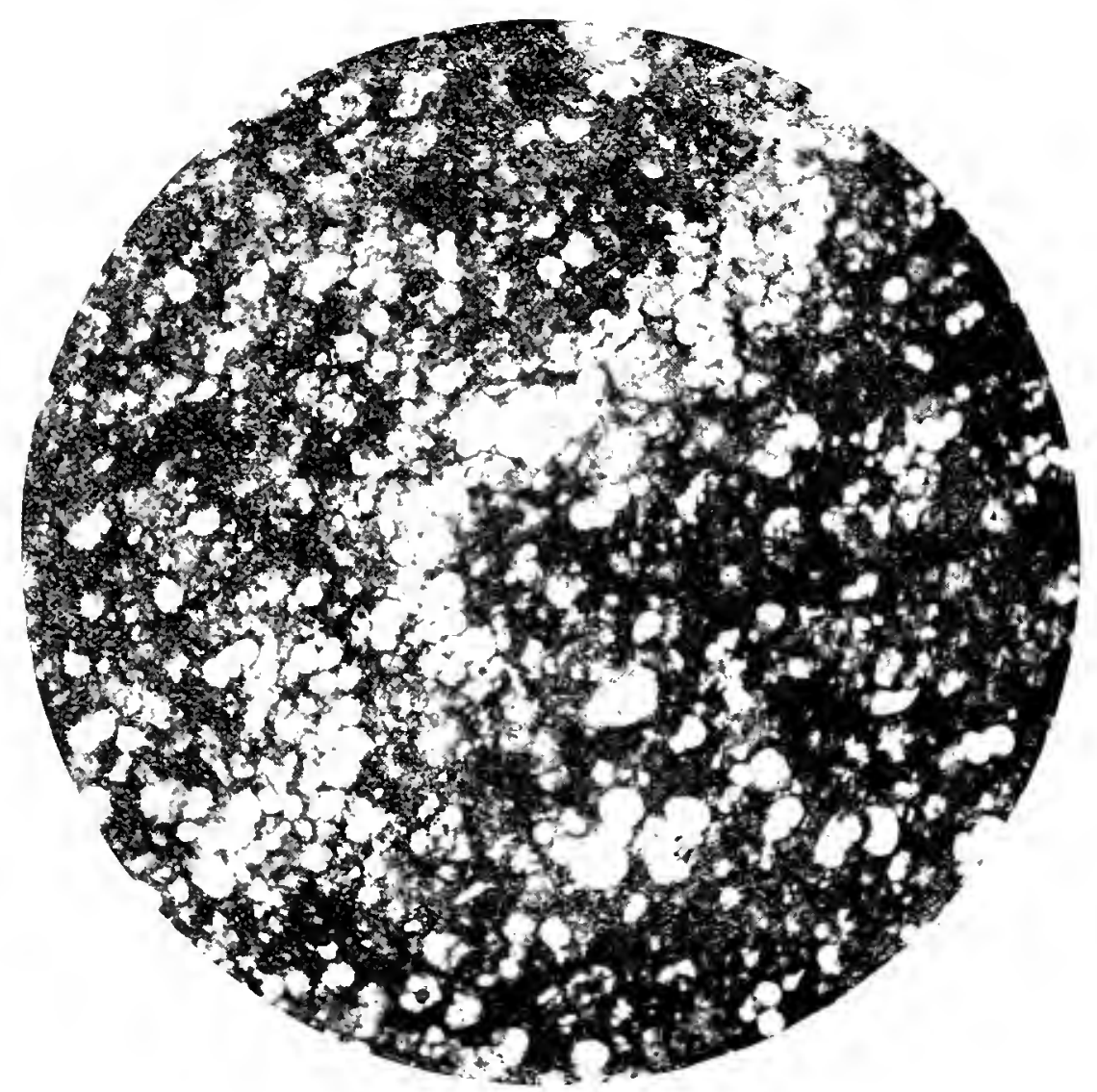

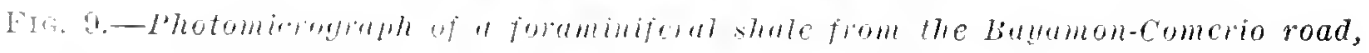
metrifinaliom se diameless

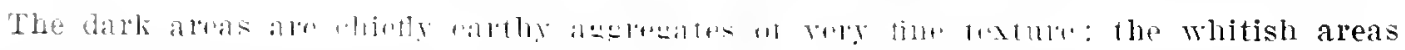

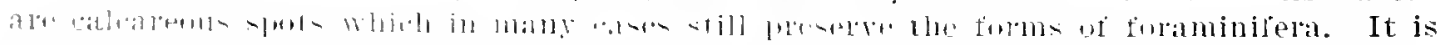

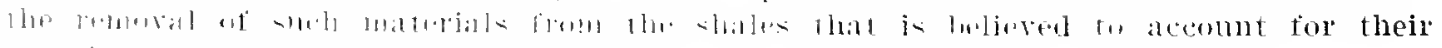

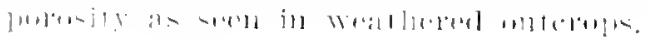

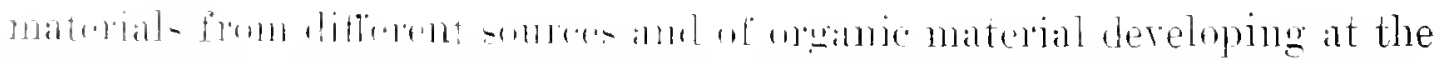

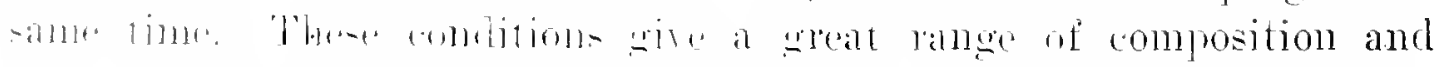

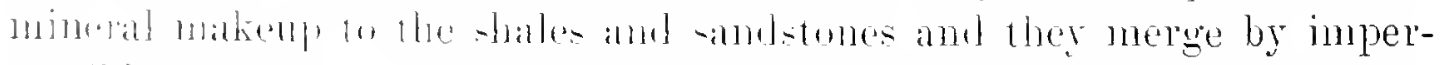

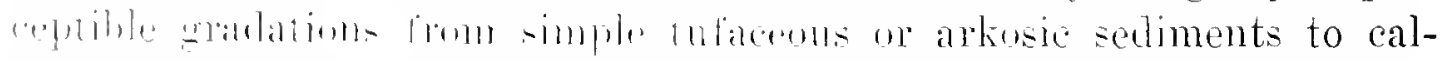

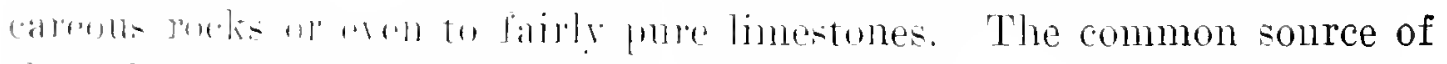

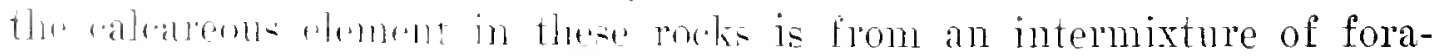




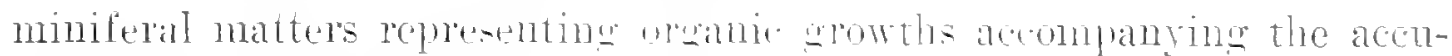
mulation of the deprosit.

The linestone members on the one side leppesenting almost pure organic accumulations. and the conglomerates on the other ropresenting the simpler desturtive rolinic franental matters. give the range hetween which an excedingly great rariety of sediments are represeded.

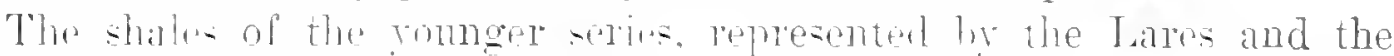

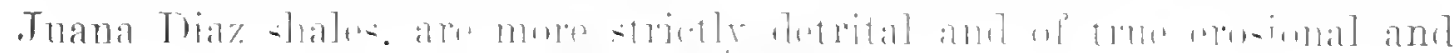

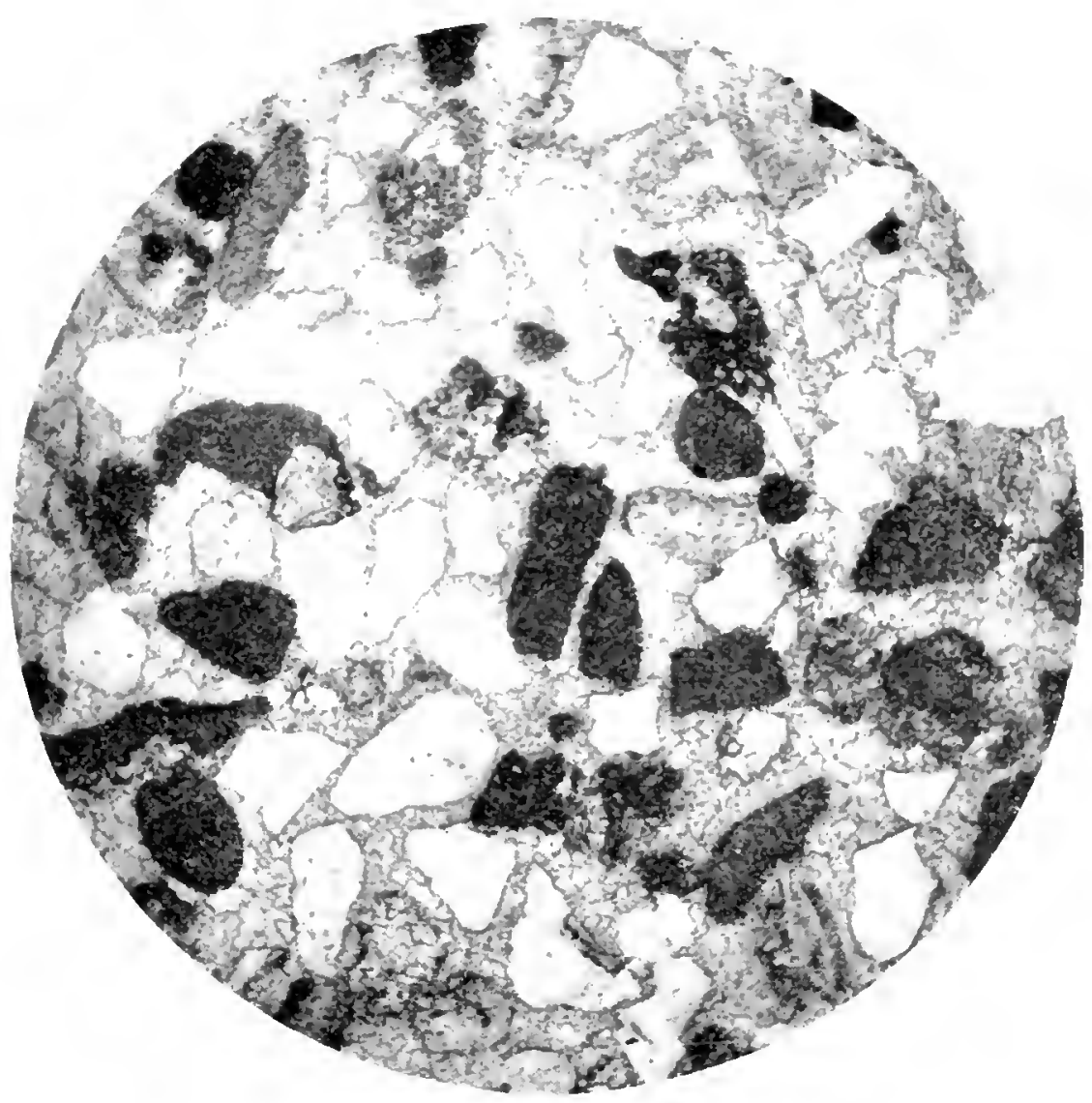

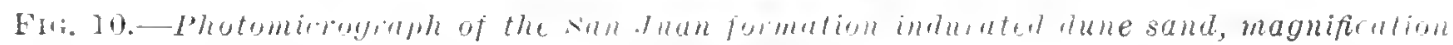
s' diumeles

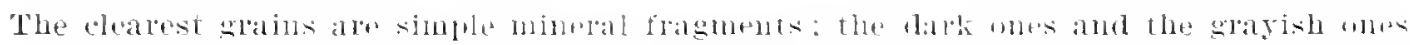

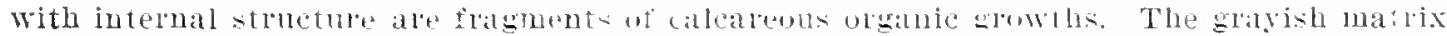
is a secondary biuding matrial of calcilie composition, in this calse practically filling the interstitiat slaces.

destrutive origin. and in places they contain lignitic material which suggests different physical conditions. 'This shows, howerer, in their upper layers an increasing amomnt of organic content also, and finally are sncceeded by limestones of wholly organic makeup. The failure of rolcanic actirity during and subsequent to that time are no opportmnity: for the amount of intermixture that is seen in the shales of the olele? series. so that as a result the romuger series of rocks is petrographieally 
more simple and less modified. The organic content is of greater variety, howerer, and because of the reef-building tendency the primary structure is more raried than is seen in the limestones and shales of the pre-Tertiarr representatives.

The most striking petrographic type is, probably, the solidified dune sand making up the San Juan formation. Its nniformity of grain. strong cross-bedded character, porous habit, together with its rather surprising stability, make it an object of some considerable interest. Sereral of these classes of rocks, therefore, represent petrographic series of munsual range and variety, and becanse of their perfection of derelopment rould seem to warrant detailed study.

There are nu foliated metamorphic rocks so far as ret seen in Porto Rico. One specimen of such rock. a mica schist, was shown to the writer as having come from the Portuguese liver not far from Ponce. but a hurried reconnoisance in the vicinity failed to uncover anthing even resembling it. The specimen probably does not belong to the rocks of Porto Rico. No evidence whaterer has been seen of conditions that would be expected where such rocks occur.

The most profoundly modified rock observed is a massive serpentine. Such material was seen at two places by this party, one near Yauco and another on the road to Comerio, and the same type is reported by Profescor Crampton on a much larger scale near Maricao. But they are al! simple petrographic cases after all, being ordinary intrusive units of heavier ferro-magnesian content than the average which have heen hearity altered. especially by hylration processes, to the present comblition. Genetically and historically, the serpentines ale not materially different from the other intrusive bodies.

\section{Depth of Decay}

Aleration has affected the rocks at most points to considerable depth. but in spito of this there are plenty of onterops, and along the roads there are many "ut pxposing fresh rock. The stream beds are strewn with

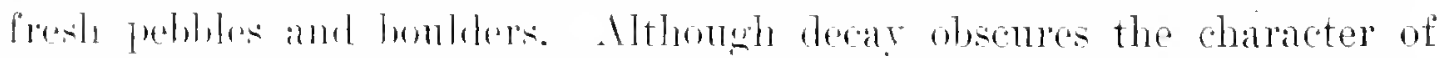
the rock in most of the ontcopos. the structure is usually fairly well presorved, and in most asts chough wn be seen to enable one to determine the formational habit.

The most striking thing about many of these hadly decared outerops and cuts is the remarkable way they stand against destruction or removal by ordinaly weathering and erosion agents. At many points. road cuts are mate. with sile walls absolutely vertical, though wholly rlecayed rock material, that stand for years without crmmbling lown. Embank- 
ments made of calth along loads and trails hehave in the same way and one is continually surprised at the steepmess of such slopes and their apparent stalility. Slopes of $41^{\circ}$ are not rare on hillsides that are cultivated, and one ocasionally crosses divides that are mere knife edges with slopes of this kind on hoth sides. Smoh stability of the soil is a great factor in prosorine the agrioultural prometivity of Porto Rieo and in the distribution of it: andoultural imbutries wer su much of the interior area.

There seem 10 be three tactors of larwe anseguence in this stability of the soil mantle. One is the dinging waracter of some of the regetation which tends to bind the soil together: another is the small range of temperature variation which reduces disintegration or disuption tendencies to a minimum: and still mother is the low entent of ine w refractory materials, such as quartz, in the pols whose destruction has fumished the soils; all of which factors faror the making of especially tenacions

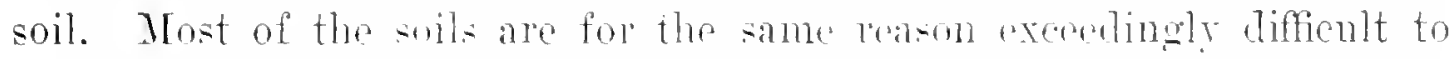
cultivate. Is a direct consequence of this soil hehavior and climatic control, there is comparatively little dus formen in Porto Rico. This is especially noticeable on the roars, where on is almost nerer in the least troubled by it.

In two districts. one on the north fringe of El Iunque along the Sabana River am the other on the north side of the divide near Adjuntas, deposits were seen which suggest wacial artion. Tery la roe boulders are stranded in positions where it is difficult to aroment for them by ordinary erosion means. hut tow little study was giren and too little eridence is at hand to walrant a mole definite statement.

\section{STRUCTLRAT FEATTRES}

Most of the structural features represented in the geologr are mentioned in connection with rescriptions in other sections of this report. This is especially true of such structures as may be regarded as essentially primary. including the interbedder and intrusive forms of various kinds. There is no dount hut that the most prominent structural combination in Porto Rican geology is represented by the snccession of interbedded sedimentary heds and tuffs. cut hy or interleaved with intrusives in the form of sills, dikes or irregular stringers. The combination oecurs in great rariety as to succession. relative amounts or proportions, quality of material. present condition and relations to other nembers, but in spite of these rariables the structural feature is essentially the same and has the same meaning ererywhere. 


\section{Igneous simotures}

The most stiking thing in annedion with the struture is the re.

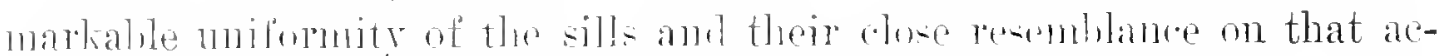

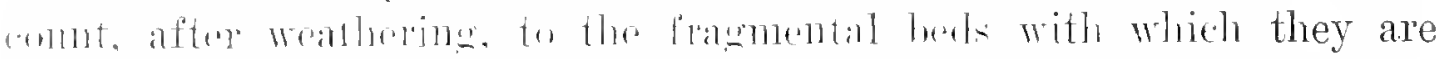
assmotate. The small amount of metamorphosing influmes that they

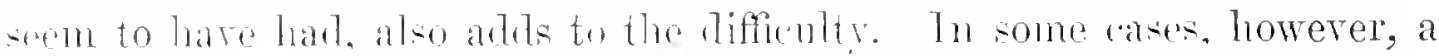
transorescive intrusion las disturloed the adjarent beds a great deal in a meclanical way.

In the average case, it is judged that the intruked magma has neither

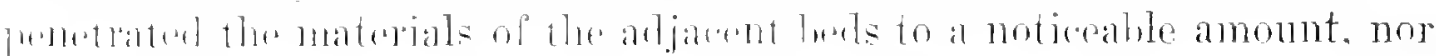

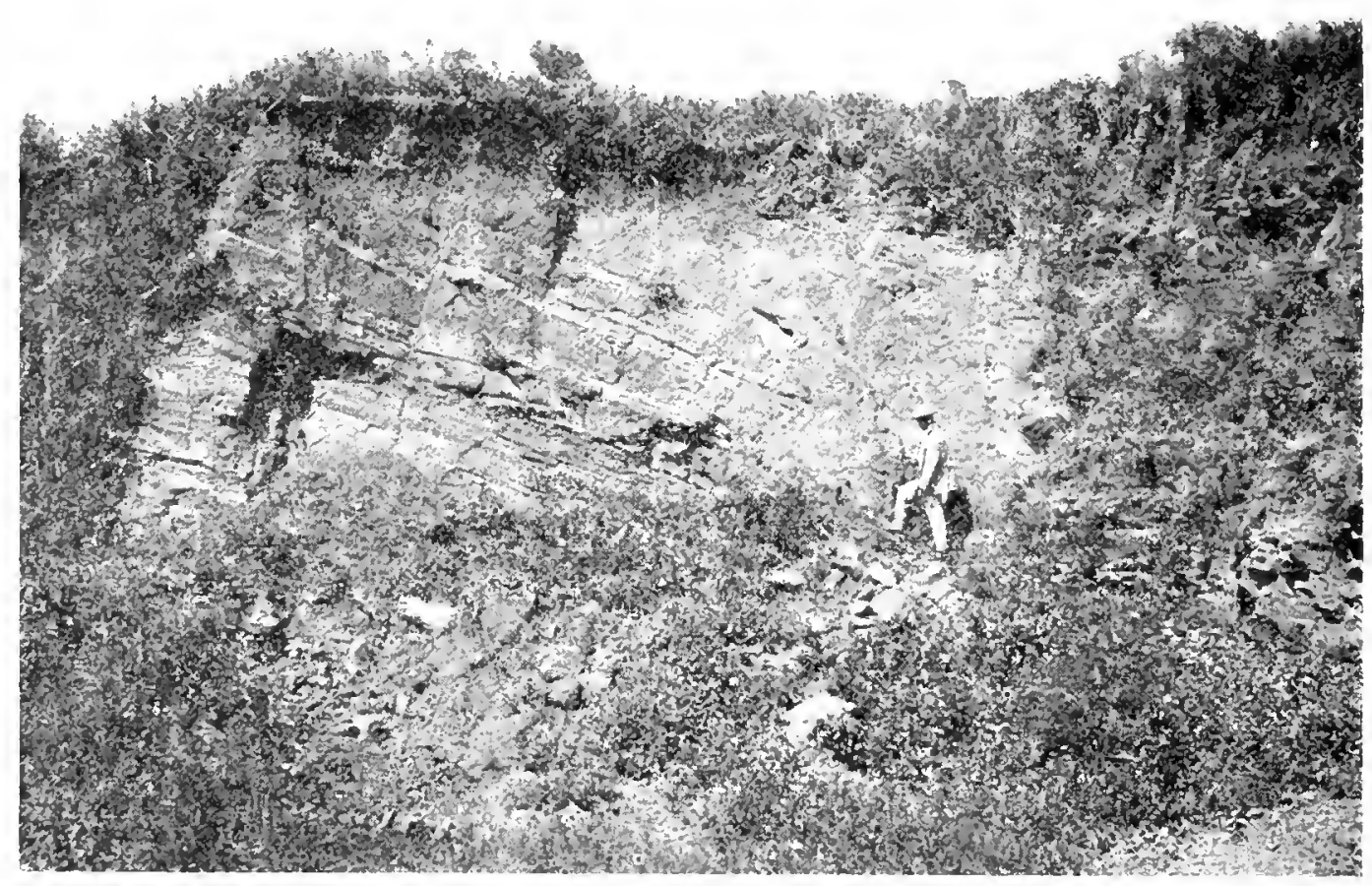

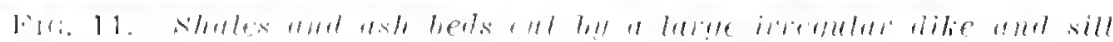

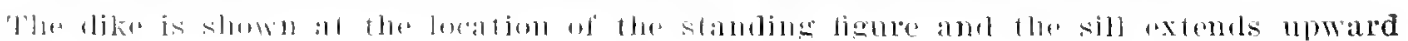

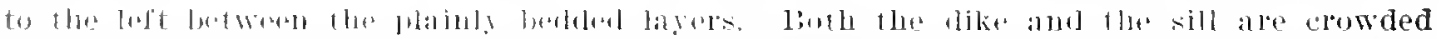

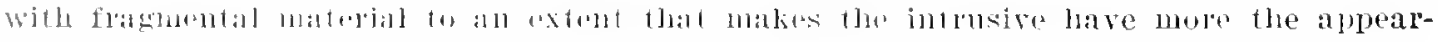

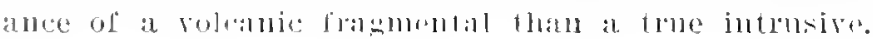

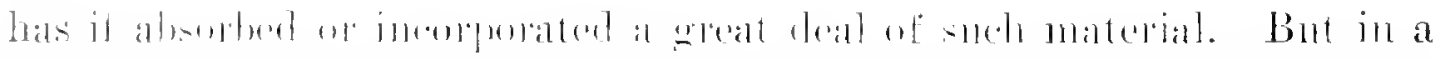

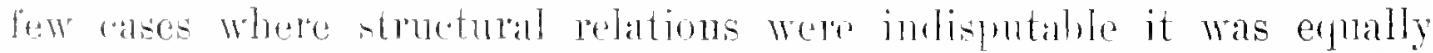
(oal that the intrusives, both transegessive and concoldant. were liter-

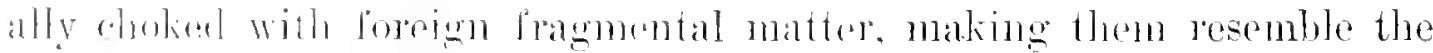
real tulfis so closely that it is doubthl whether the dillerence would have

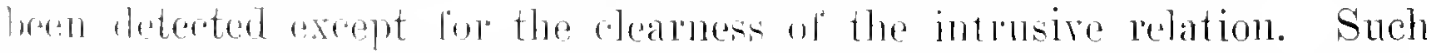

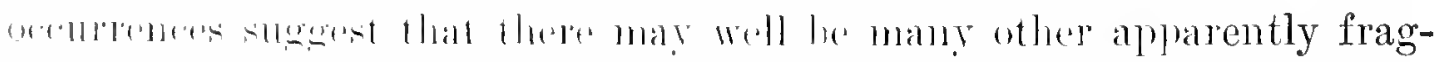
montal interbeds that are in reality proment-clowered intruses. On ac- 
rount of the great abundance of the fragnental matter. it loes not seem possible that these intmsive mases rould penetrate in that condition to some of the positions where we now find them. It is more likely that a lather fluid magma has penetrated some umsually porons fragmental hed forming a matrix for it. perhaps also sprearing it somewhat. and then in breaking across to another bed. in sone cases it was still mobile onough to riag tho mixture alme into the larger transeresive structures.

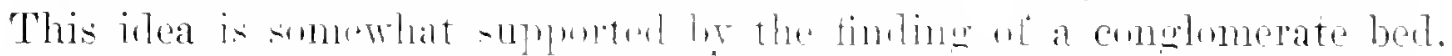
near K-S6 on the military road west of Aibonito. immrenater with an inneous matrix in essentially this same mannel. In ardition to these forms, there are numerons larwe intrusire masses. the largest of which descre a special name. I see no objection to alling them bosses. The two largest occur. one hetween C'acuas and the Caribbean sea toward the south and southeast. and the other lwtween. Janya and Tomatn wn the north side of the divide.

\section{Tolranir Tent Complexes}

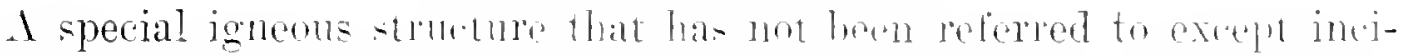
dentally is that composite of ristubed structures which represents the foration of old roleanic vents. They are essentially a complox of irresular intrusive units cutting and inculing masses and ageregates of various fragmental and sedimentary types in a mixer relation. In the clearest cases, such a complux slldhenly takes the place of a formation of apparent promise of continuity such as a series of sedimentary beds, and alter an interval these bels are again found contiuming as before. For example, the Coamo limestome formation is abruptly cut off and its place is taken for a mile or more by one of these igneous compleres. the limestone continuing on the other sile again. The Tacagnas reservoir. just

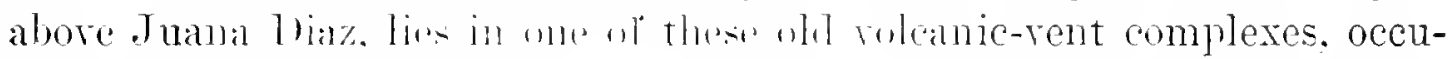
pying, however, only a portion of the area. Another such case is represented by the complex cutting the great conglomerate beds on the military road at about K-Si-SS west of Aibonito. Another is believed to be represented by the very striking basin-like area crossed by the road between San German and Hormigueros. This one is now represented by a very smooth plain five or six miles across surrounded on all sides by more hilly country. The same conditions are undoubtedly indicated ly the extremely complex structures seen on the Descalabrado river two miles below, south of the military road. Some of these mark the sites of ancient craters, clogged or choked with fragmental and intruding materials. 


\section{Fotiling}

Nost of the rock formations representing original bedded types have been more or less tilted or otherwise lo not mow have their original attiturle. Those belonging to the romger series, the Tertiary limestones and shales on the north sile of the island, are comparatively little disturbed, and in some cases do not have a rery ditferent dip in spite of the fact that they have changed rey much in position with respect to sea level. On the sonth side of the island, howerer. even these later beds are in many places tilted at a higher anghe than they has in the begimming

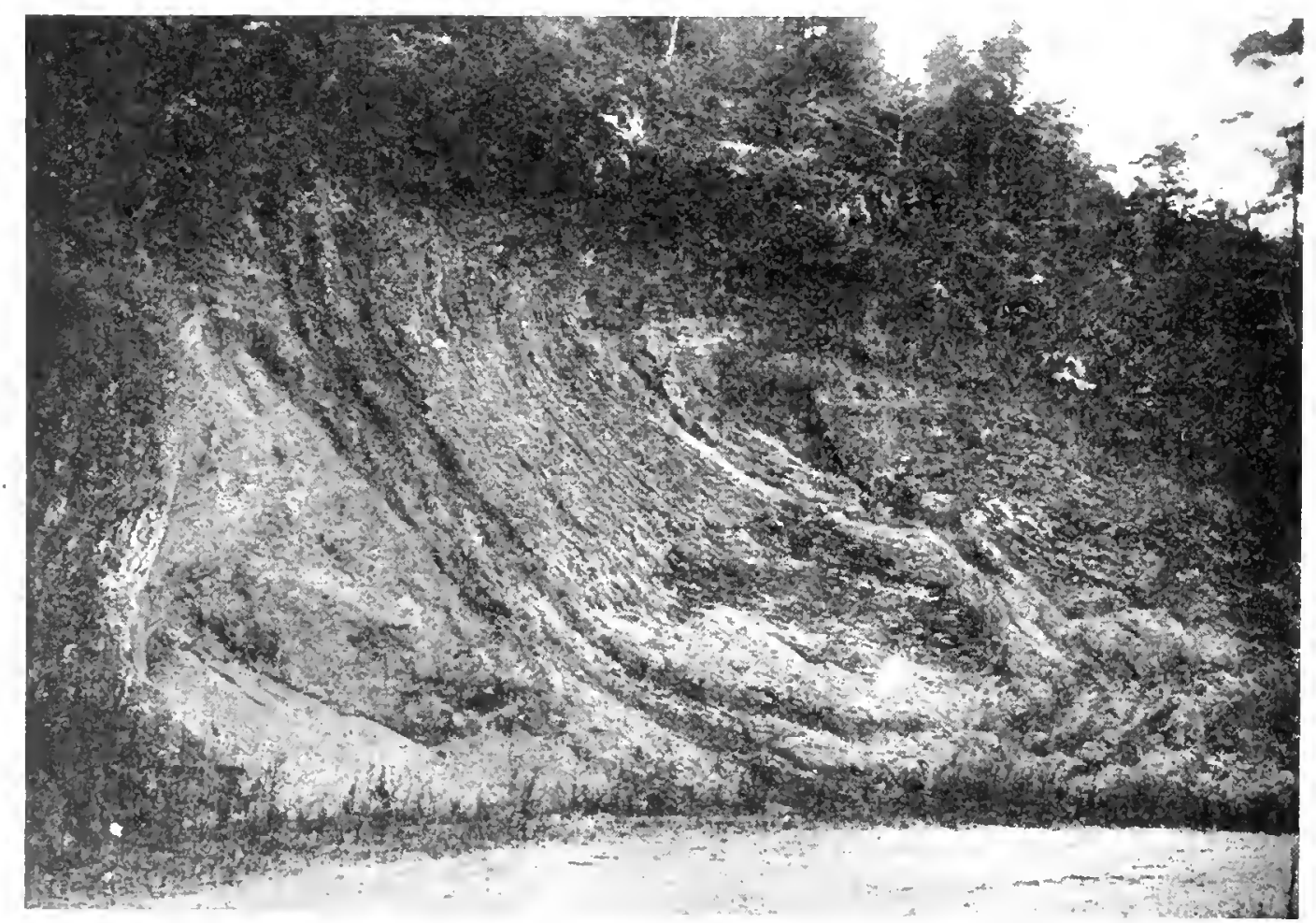

Fig. 12.-Oertumal fold and crush :ono in fincly bedded shates on the Jaynya road near the summit of the range

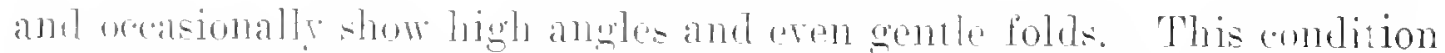

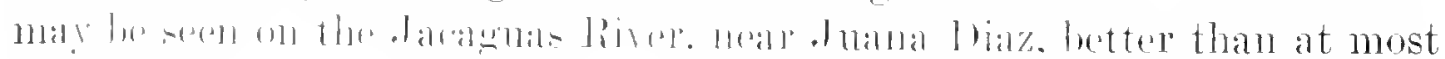
plawe, lut similar conclitions are indicated by the relations at certain point: Parther west. This connition on the south side of the island indicates more extensire and more violent dynamic disturbance on this side. which is further supported by the presence of fanlts cutting and affecting the Tertiary series on its present inner margin.

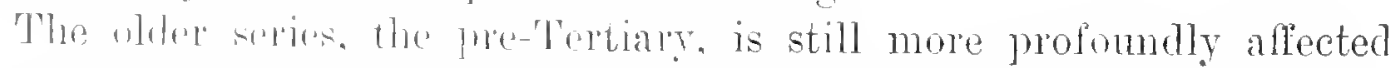
and, in almost all districts. slate and ash beds may be foumd standing at high angles, in man! (aws practically vertical, and in occasional instances 
erumpled and overturned in a most emplicater manner. Minor fold structures of this kind are esecially prominent in the higher ranges, for example. along the Jayura roal along the divide opposite station K-2t of the Ponce-Arecibo road. At such a place may be fomel as complicated structural features of this hind as is usually present in any folted momntain rewion. The high angle at which such beds stand at many other points leals to the helice that sinilar complexities characterize a great many of the distrets ocemping the higher momtain portion of the island as well as some of the maroinal areas. but the great amount of erosion and the rery limited exposmes at most points tent to obseure some of these details. The complex way in which the inneous intrusive masses cut all of these formations also tends to ohsenle and modify and further complicate the simpler foll structures so that it is not always possible to properly credit the disturbed attitule. On acount also of the fact that the total quantity of injected or intruded materials, including dikes, sills and bosses. is exceedingly lare and must have caused extensive disturbances hy reasm of the displacement produced hy the ocempation by these intrusive mases, it is likely that much of the observed abnormal attitude of the hedled rocks may be due to this cause rather than to regional folding of a simpler sort. It is fair to saly. howerer, that a sufficient amomnt of lata is not yet arailable to draw general conchusions as to the meaning of the fold structures in Porto Rico. 'The striking thing is that all of the older formations are disturbed and that their position and attiturle, even along the magins of the island. indicate that the region affected by these morements was more extensire than the present land area.

\section{Faulting}

There are many evidences of faulting on a small seale, in some of which the displacements can be measured. But in most cases the direct evidence lies chictly in the existence of crush zones, slickensided walls and abrupt changes of rock type; there is no opportunity, on accomt of the general rock complexity, to secure quantitative data. Jndging from the difficulty in tracing certain formations between districts where they have been identified, it is probable that there are occasional faults of large displacement. Numerous crush zones were seen un the Comerio road especially, but in this case also no systen was discernible from the few measurements available.

The most prominent fault. in its effect upon present features, is the one now marking the imer marwin of the rounger series of chalky limestones and shales constituting the coastal helt along the south side of the 


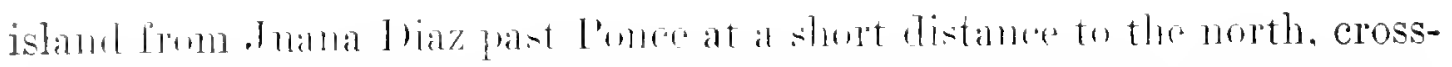
ing the l'one- Mreithe road at $K-4.8$, and thence westware erossing the Ponce-Penmeds roal at $\mathrm{K}-10$. This is the only large fault actually observed that is mowstrily of recent ase. although a few others are inferred.

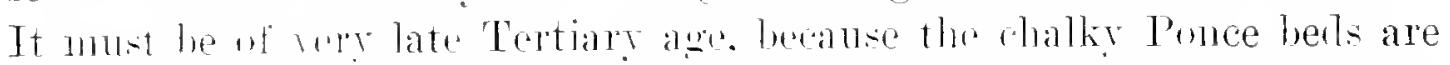

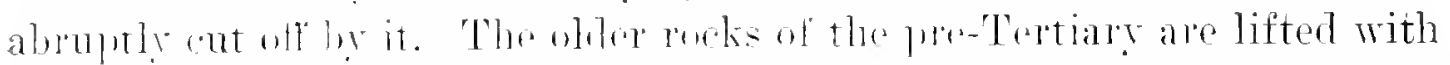

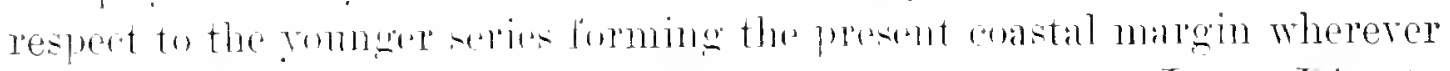

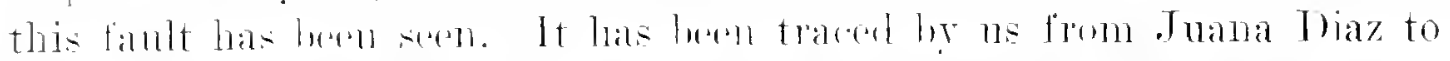

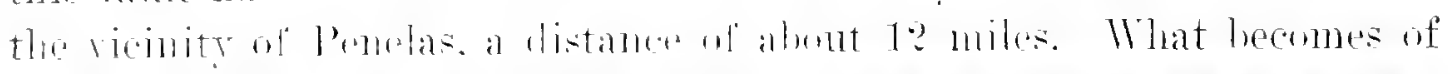

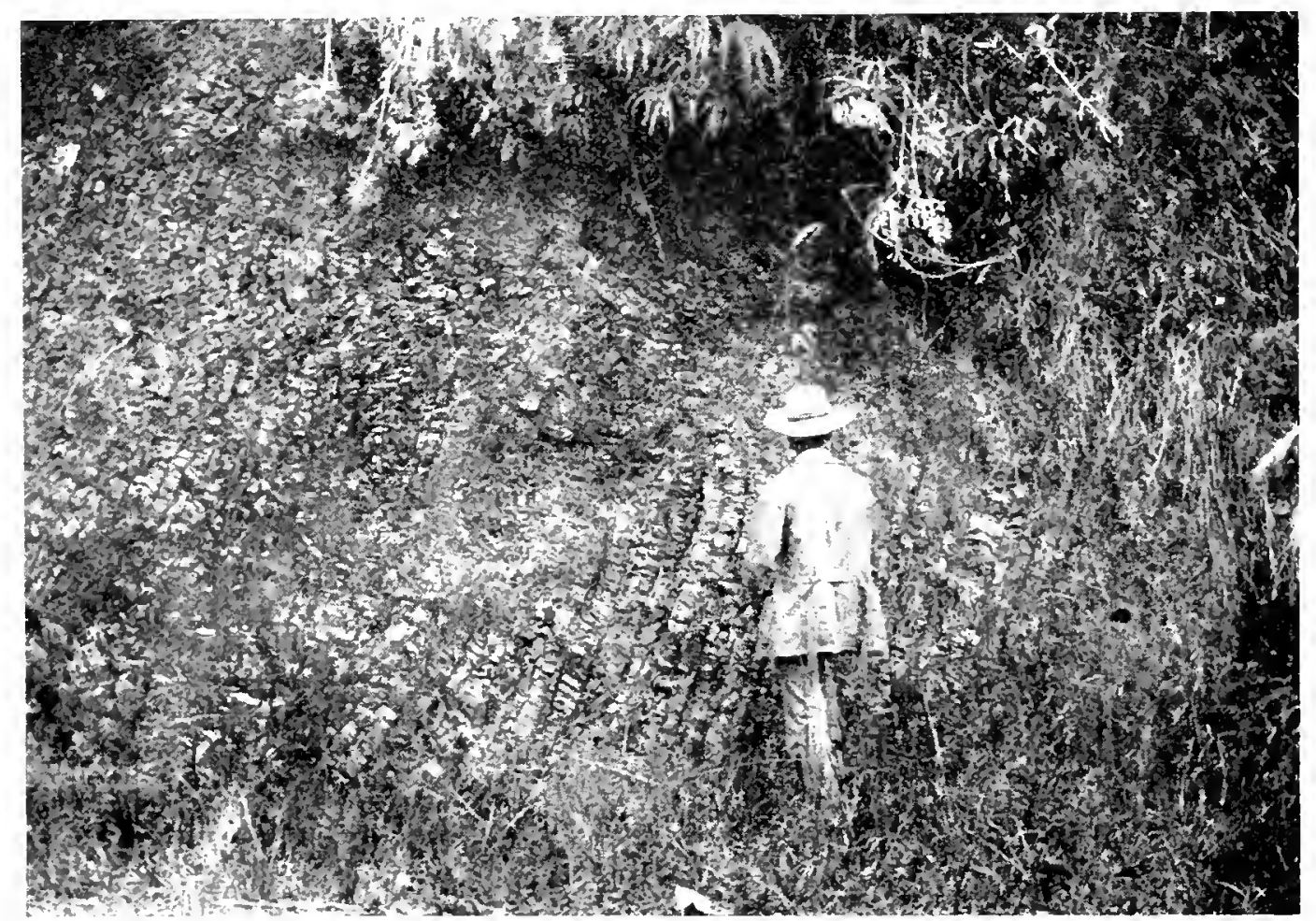

Fig. 13.--Crumpled shales as scen atong the Jayunn roal near the summit of the range

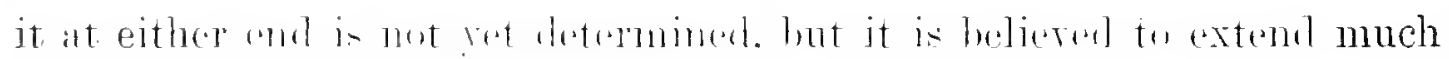
farther in hesth directions.

The phrsiographic habit of the island as a whole tends to support the

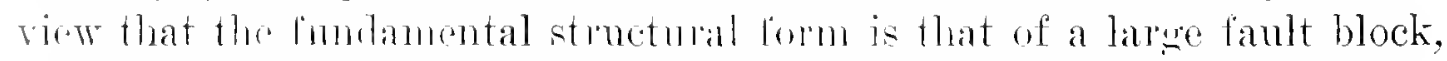
with the primeipal lanlt displacoment and uplift along or noar the southelly margin. tiltime the whol, mas gently northward. If this disturb-

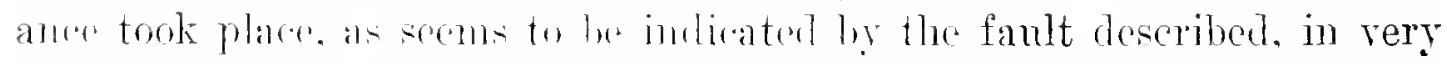

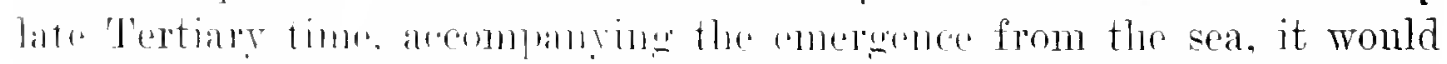

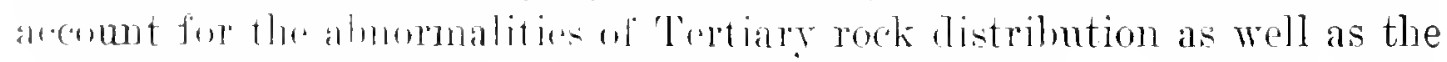
unsmmetrical pesition ol the main hrainage divile. In any case, how-

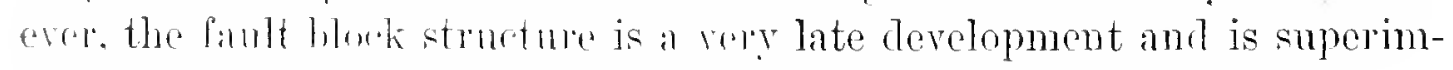

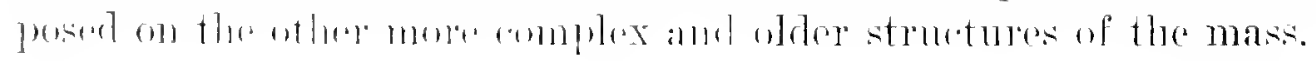


The island is compatratively ahoupty teminated at buth the east and

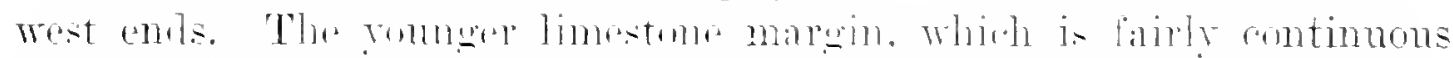

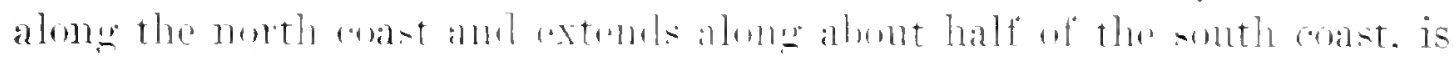

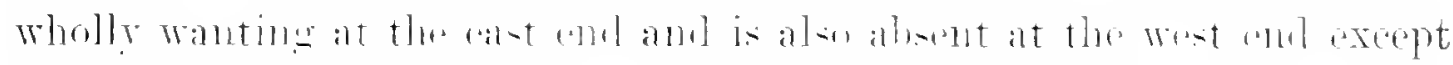

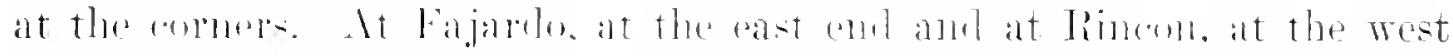

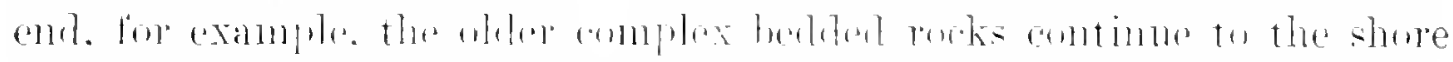

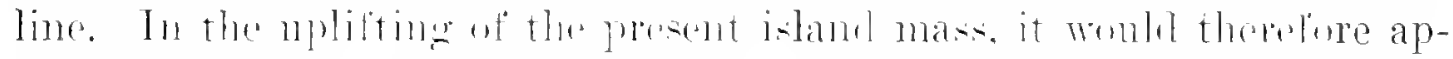

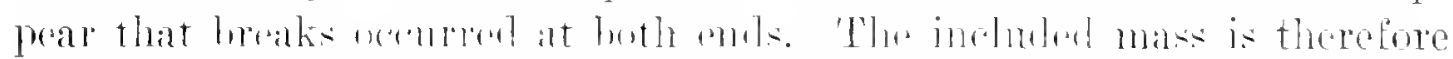

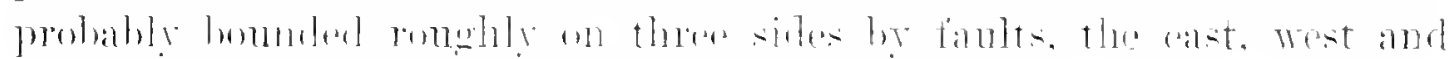

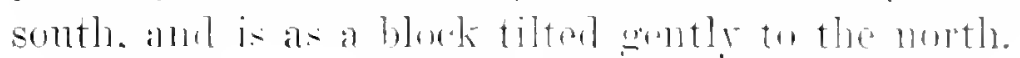

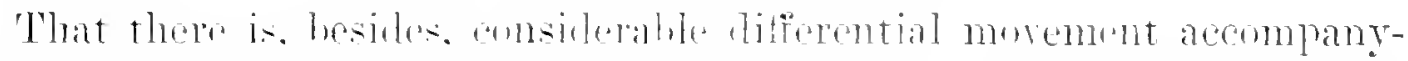
ing the uplift and listurtane is mblicated by the waping of the erosion

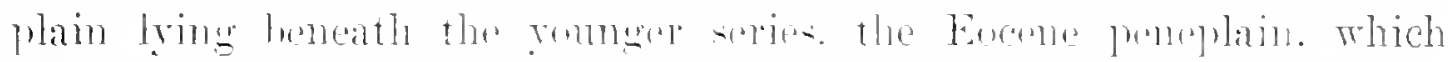

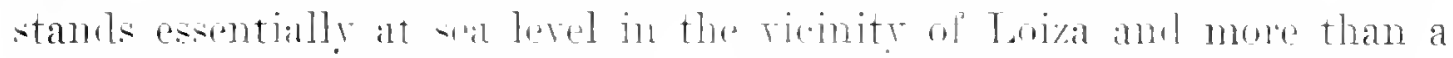

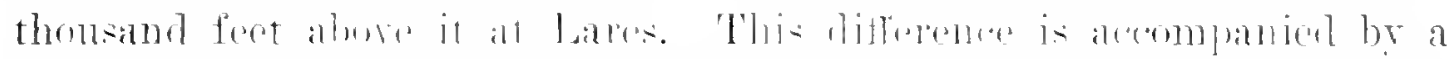

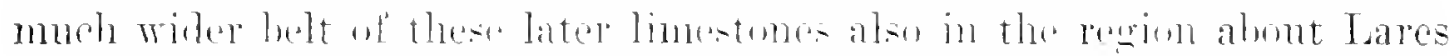
than olsewhere. Surle waping need not of pompe be confined to the last

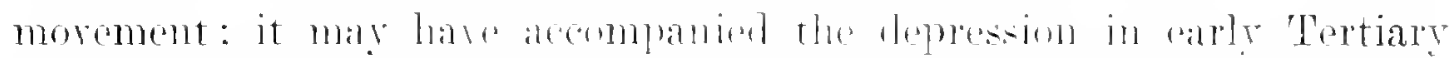

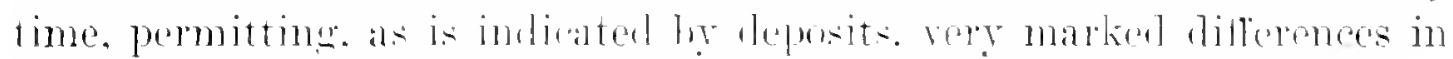

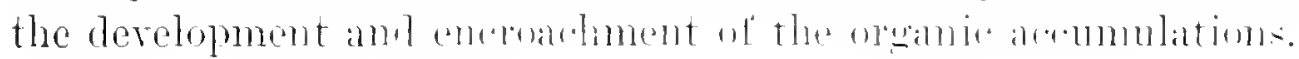

\section{Larye struetural Gromps}

Where rock formations or fieht mits are so mmoroms amel so closely related and so complex in prinary structure it taken in retail, it is adrisable to combine them int fewer more generalized groms. I first step of a very general sort, but in all respects sound. has been taken in recognizing and using the torms "Tomnger Sories" and "Older Series" in this paper. In additional step has ben sngested in rocugnizing certain smaller associations under the terms San ,Tuan Formation, Irecibo Formation, Coamo Linestome Formation, Tnama Diaz shales ant marls, Fajardo shales, Sierra de Cayey tufls, Ponce chalky limestone, ete. but these are for the most part locil designations. some of which nay well be expected to become mncessary after complete correlation is established. A good structural basis for somm sublivision of this sort is not ret worked out.

\section{Unconformities}

There is only one marked mnconformity in the structure of the island. This is between the younger and the older series. It measures the break in the sedimentary succession represented by the erosion interval during which this mountain mass. now represented by Porto Rico. was rednced 
to a comparatively monotomoms surface for the most part at least near to the sea lovel. The time interval need not have been of rery great geologic value, but it represents the time between the last riolent outbursts

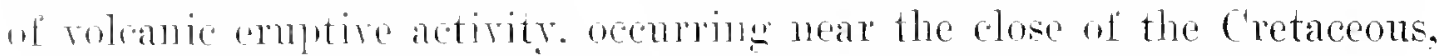
and the lowimning of simple sedimentation and limestome reef develop-

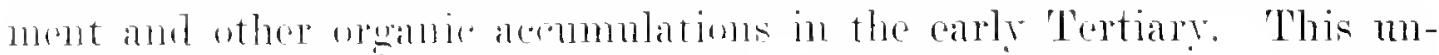

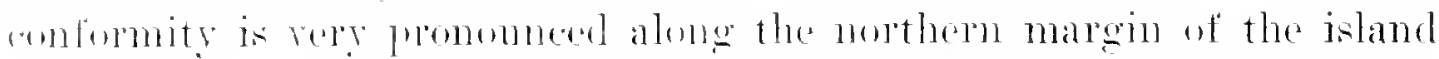
whored the two principal sories ol formations are well developed. This is nut casily seon on the somth side. lont the relative complexities of attitule of the two series. tresther with theil pwition, emphasizes the same fundaneutal relation. This brok in selimentation is not anywhere marken by a dorndement of a hasal comglomerate. In some places the now series is indugurated he the herelopment of shales. part of which are

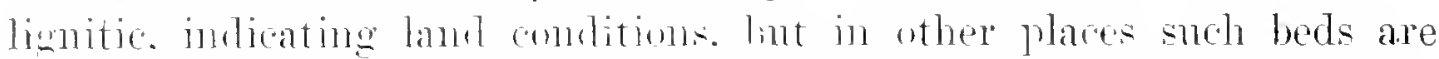
entirely wanting and the uptumed conted members of the older series are followed ahrupty by limestenes of the roet type. The first type of sucession is illustrated in the vionits of San Solastian and Lates and the latter type of alompt limestome suressiom by the comditions seen on the Irecibo Risur. It is entirely likely that the time ratue of this loreak is not erepryhere the rame. Probahly the districts in which shale heds

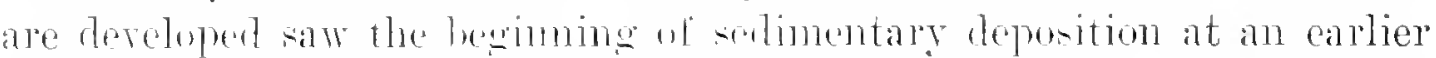
period than thoe in which the shates are entirely lacking. It will be pos-

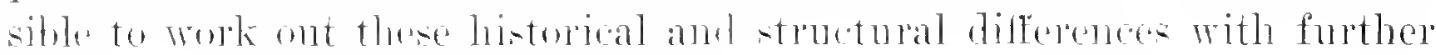
stmily of the content and distribution.

1 rere extensive lereloment ut anglomerates in the region immediately west of Aibunito and smaller oceurences at sereral other points. copecially on the comorio roar south of Tayamon and also near the military road in the vicinity of La Muda. have a suggestion of the possibility of a rather important structural break, but there is thus far no conclusive evidone of the presence uf any real unconformity.

\section{Trins}

Quart\% reins are not prominently resoloped. There are occasional quartz stoingers and in a low places they are abundant enough to make a sort of not work, but in no instance was a large persistent fissure vein seen. Th whne cass the stringris of quartz carry values in gold, and in all probability they are the source of the placer gold known to exist in certain distrirts. So las as ohservations hare been made. there is no par-

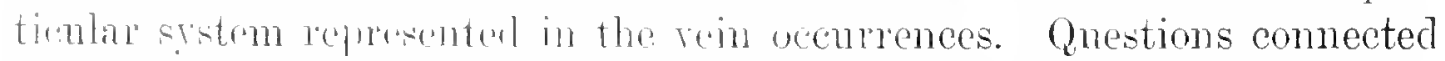
with this subjert turether with mineralization and possible value as

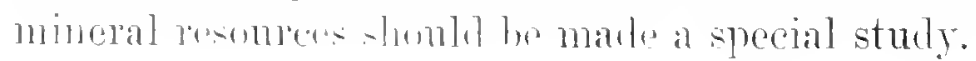




\section{limor structures}

Although there is extensive development of sedimentary formations which have been subjected to much distrubance. there is comparatively little structure of a minor sont that scens to deserve such discussion in this lestription. 'T'wo. howrerer. that seem to have special significance connected with the oriegin ol the particentar beds which have heen found

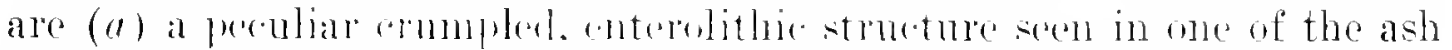
beds near Grugama, and (b) the winl-assorted aros-bedling structure of the old hume samk sol the sim . Tuan formation at Arecibe.

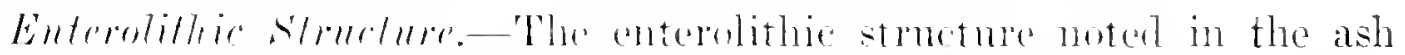

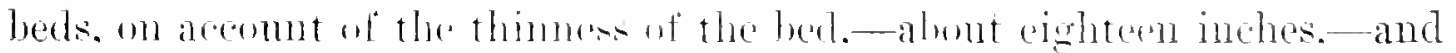

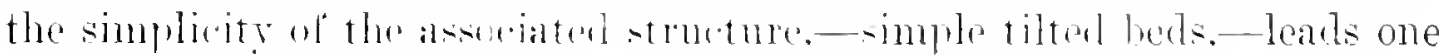
to believe that the strurture is encentially primary rather than of subse-

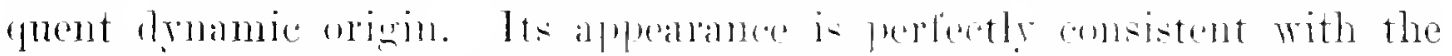
explanation that it is preserved from the time of deposition and its behavior at that time as a small mul flow. It is a struetmets sheh as might be formed by stmmping morement of a soft layor. It shoml be expected that there womld he lowpent behavion of this kind in the acemulation of such extensive berk of ashy matcrials. which must in sume cases have heen deposited muler anditions that womh make smmping movements possible, hut it is not to be expectent that material of this kind would in

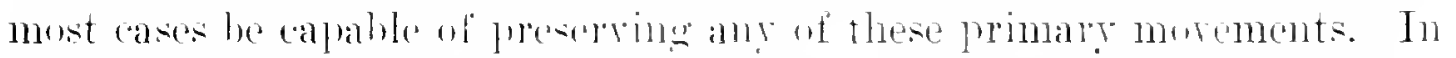
the case noted. the quality of the interior makenp of the bed seems to have been more lavomable to such pleservation. It is the only case where such an ohservation was marle.

Double cross-beddiny.-The cross-bedding strueture belonging to the San Jnan formation is a prominent featme whererer these ancient dume sands are preserved. I great provalence of steeply inclined minor structures is crossed hy fewer nearly horizontal ones. Measmements made on sea-chffs a short distanco west of Arecibo. where this rock is very prominently dereloped, wave dips of 30 to 3.3 degrees repeatedly. I series of these is abruptly terminated by a more nearly horizontal hedding for a comparatively short distance and the wole structure is repeated. The layers with this kind of structure are prevailingly one-halt to two feet thick and no ripple marks were seen on any of the beds examined. The cross-bedding structure in this case dips always to the west or southwest, and the arerage strike of the principal beds is about north 30 degrees west. This is consistent with a wind direction not rery different from the present prevailing winds. Very strong structural development of this kind is also to be socn in the city of San . Juan at the promontory on which the 
Norpe is built, but measurements of orientation were not taken there. An wermeremer of this rock immediately to the cast of Arecibo, a short distames south ol the lighthouse, showerl structures of this hind on a mmbh laterer solle than was seen elsewhere, and with an espectally interestime combination structure. The principal or stronger hivisioms are whloly sabated and lic nealy horizontal. A comparatively small hed lying in this position was almost mucomsolidated. but those strongly cross-

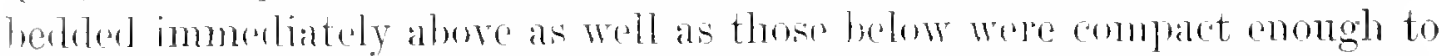

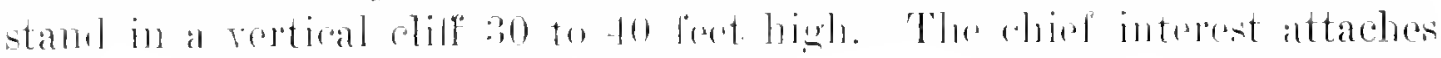

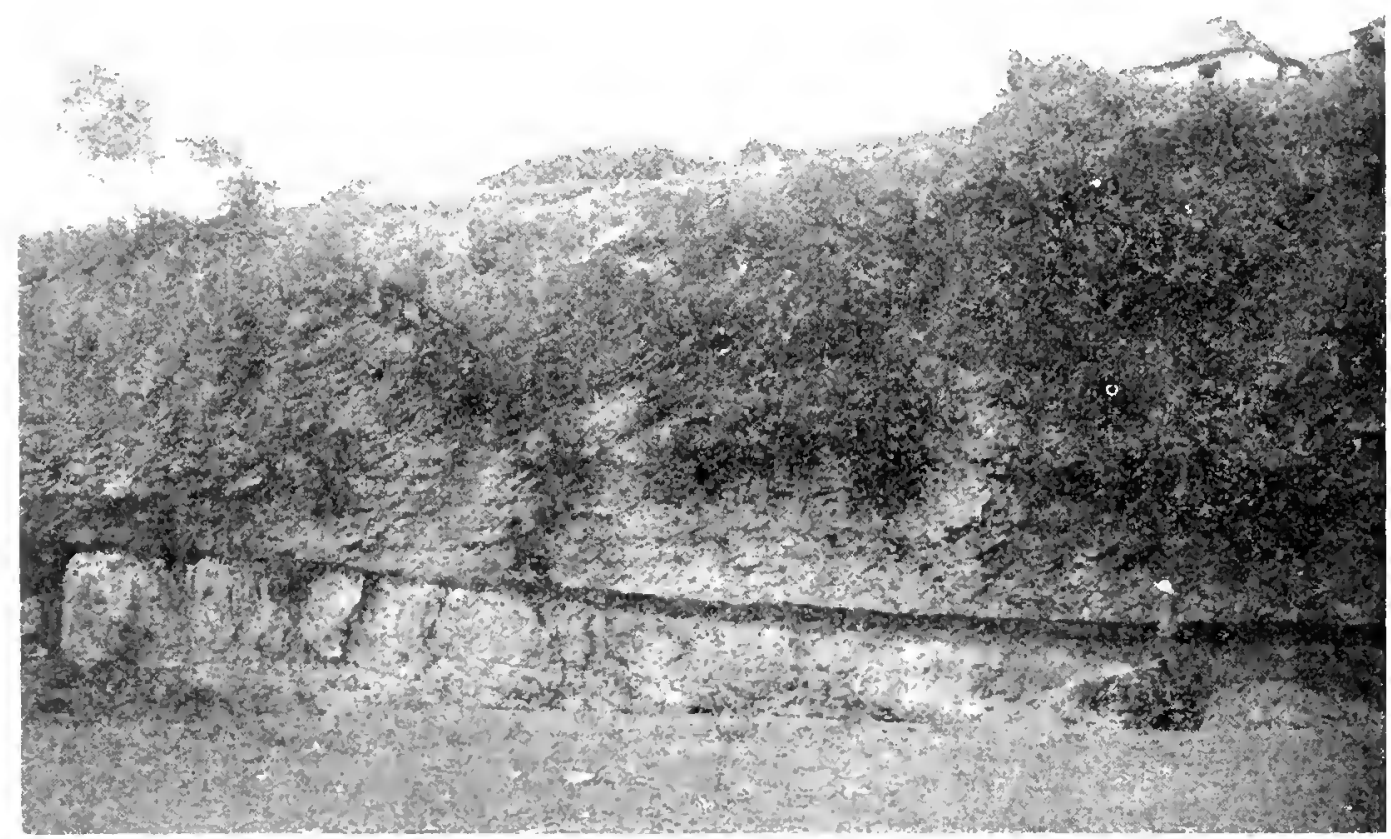

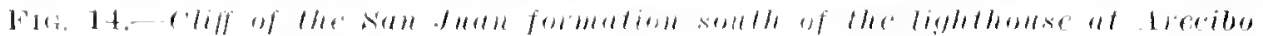

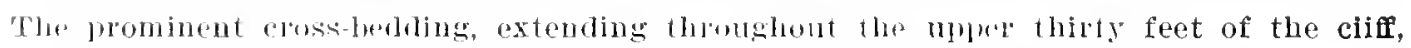
is woll shown, togrolur with a less strongly marked horizontal structure crossing the sitme luils. The prominent break near the base is made by a layer of sand which is very froorly consolidated.

to the stromgly cross-bediled portion forming the upler twenty feet or

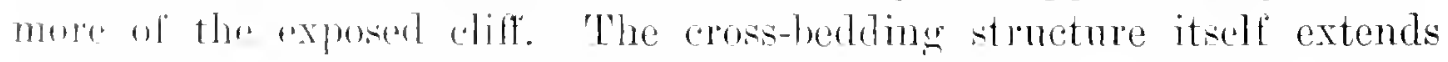
whlunt intermption throm a much greater vertical range than in any other outerop examined, but its attitude and dip were not markerlly difforent: He frature that was strikingly diflerent low the structure seen mymhere alin was introlnced by the presence of less prononnced but still very plainly manked horizontal structures. making an interpenetrating mosh-like alriugemont in the face of the diff. 'This ean be seen strongly enough to show in a photograph eren at a distance of 100 feet. It is cri- 


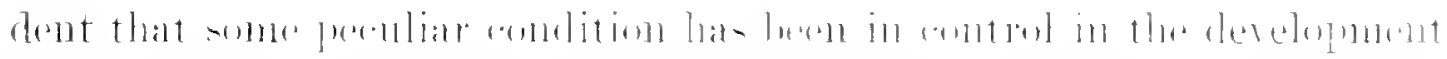

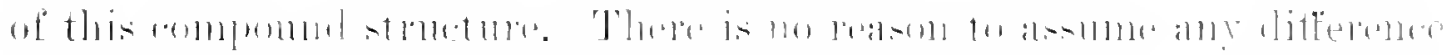

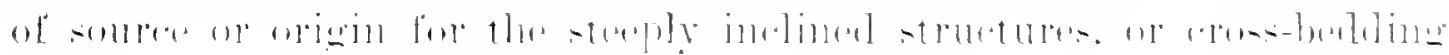

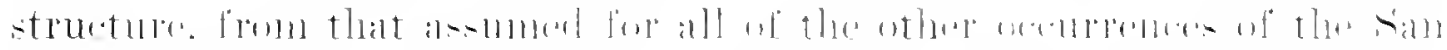

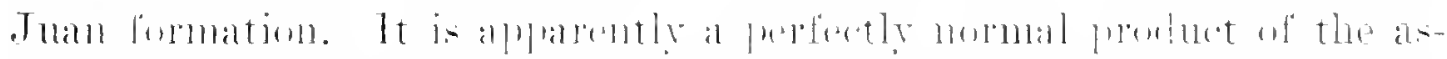

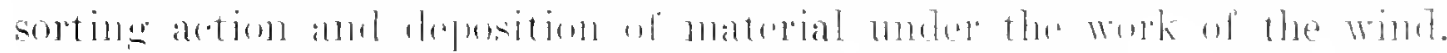

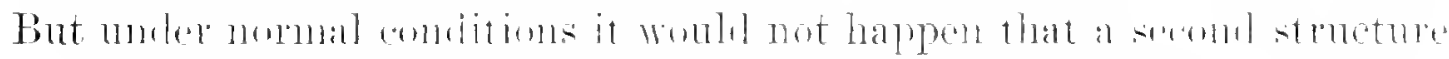

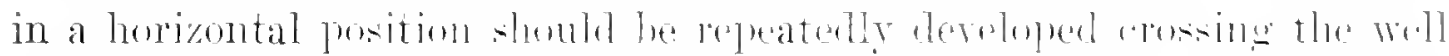

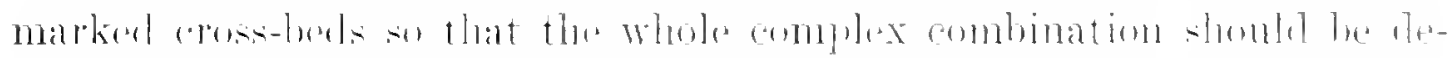

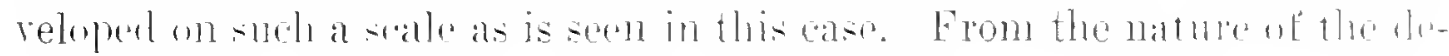

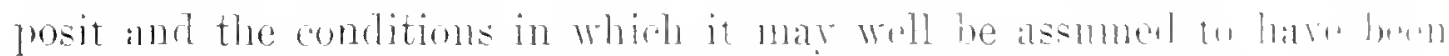

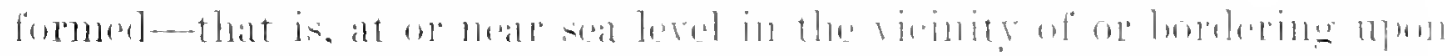

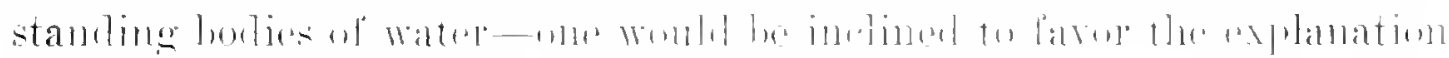

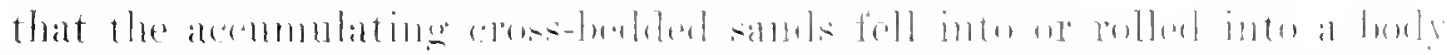

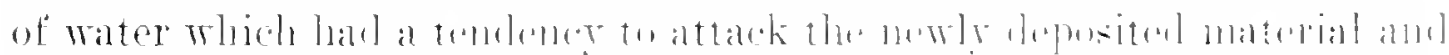

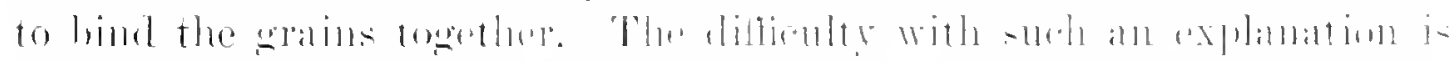

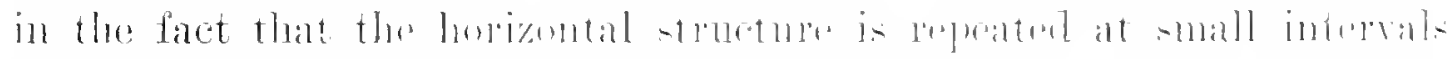

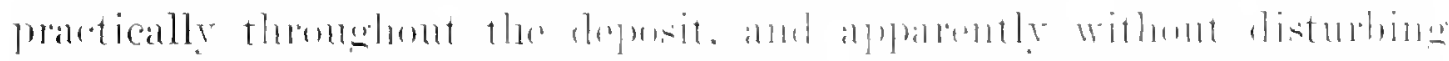

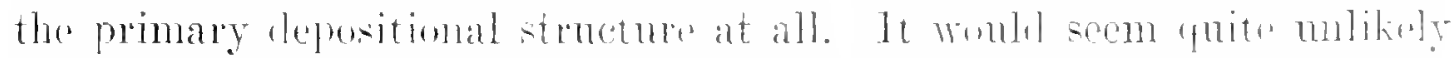

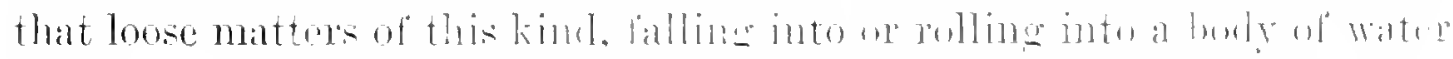

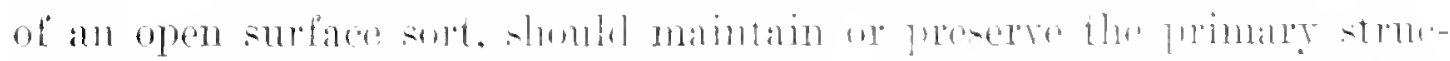

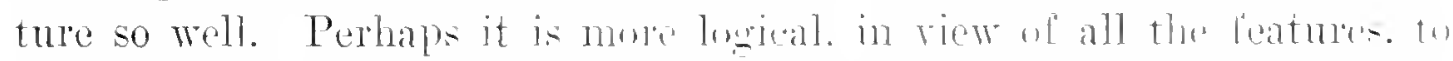

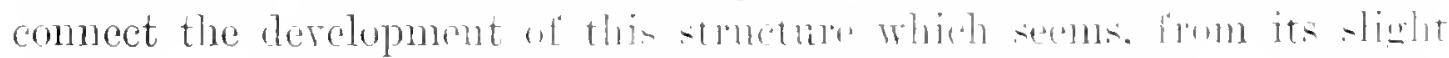

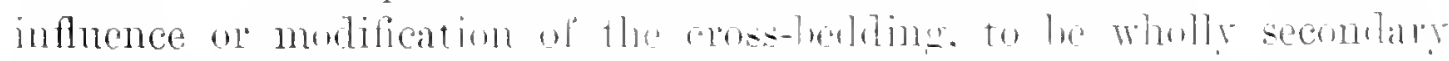

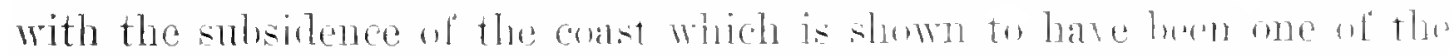

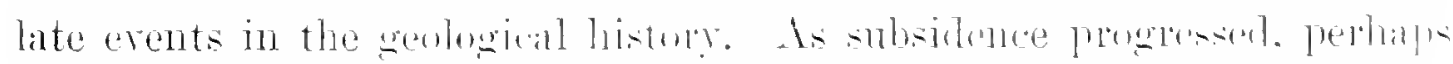

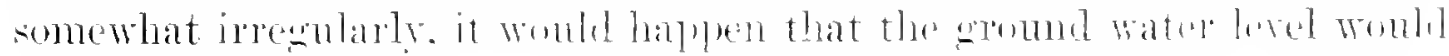
rise correspondingly high in hels that were passing below sa herel. It the surface of this gromul water level the tendency wombl be a a a complints a binding of the gramular materials together. Both above and below the ground water level there would probably not le so stronge a tendency to derelop this binding. With the next step in the progress of subsidence. another streak of indurated zom would be established and these have been repeated thromghout the whole formation during the whole perion of subsidence. An action of this kind wonld not tend to disturb the primary structure at all: it would on the contrary tend to perserve it or make it less destructihle beamse of the improved imduration. But it could, in addition, develop a suression of secomaty structures throughout the whole mass which, if the binding is fain substantial, might rival the primary structure in prominemes when exposed to sulseguent de-

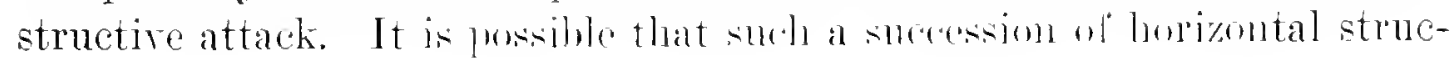




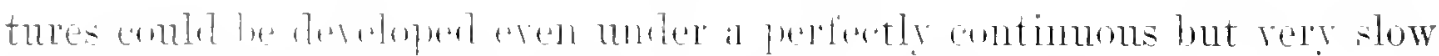
subsitence momment ly reasun of the natulal seasonal sound-water

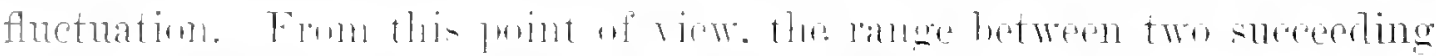

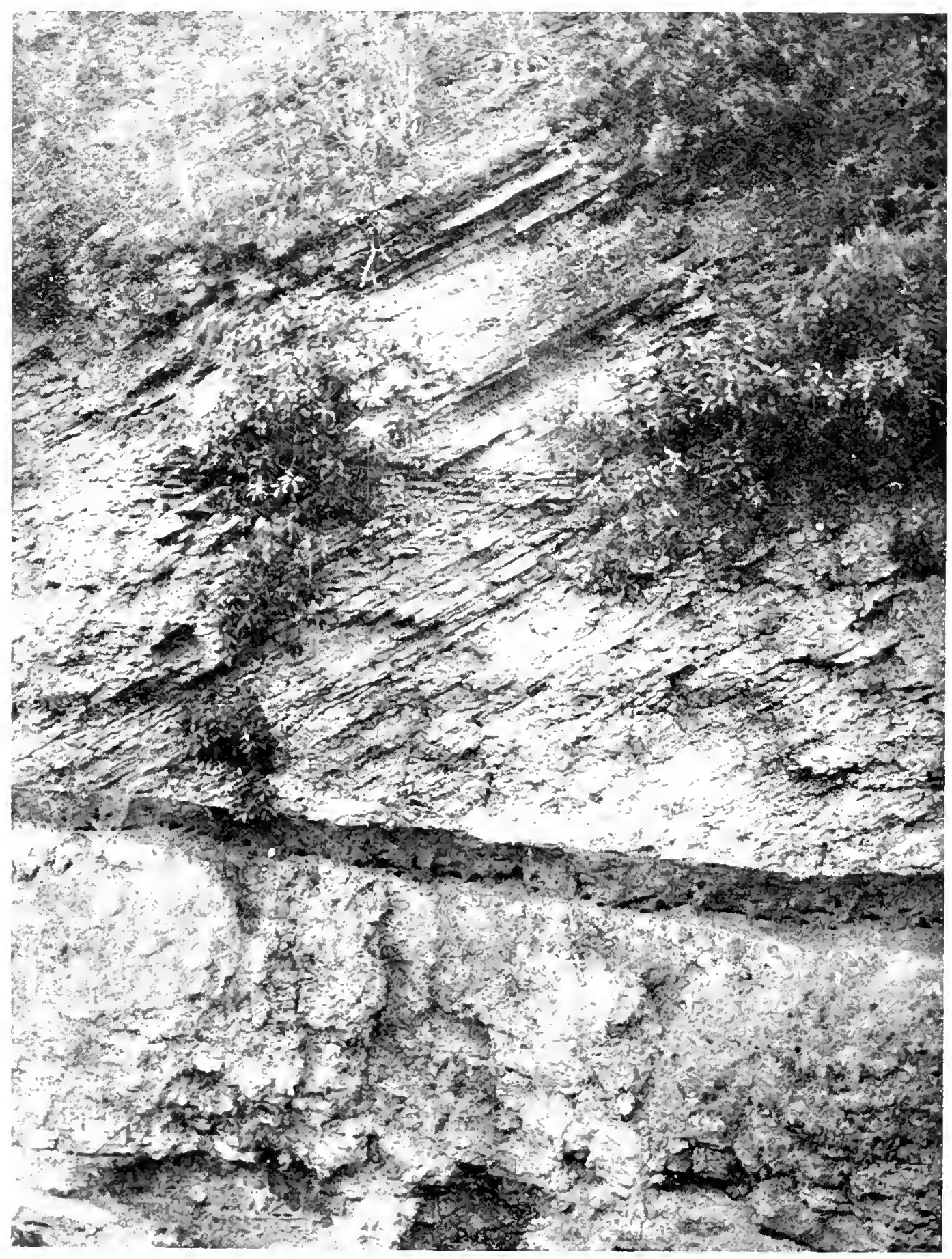

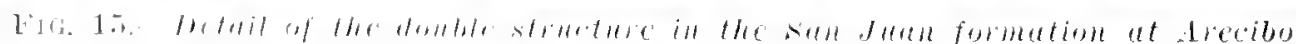

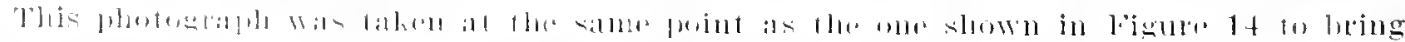

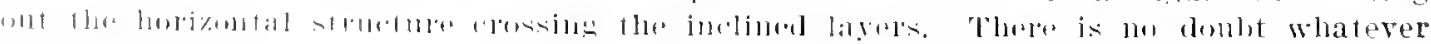

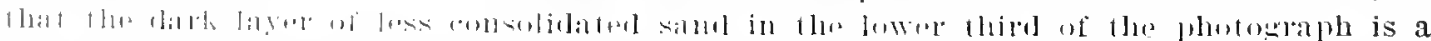

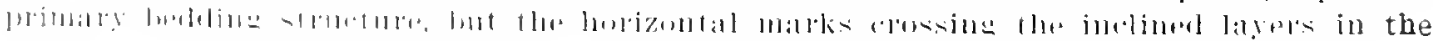

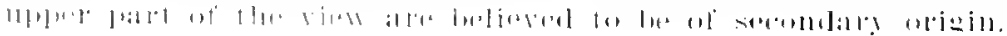


horizontal markings would measure the fluctuation range of the gromul water, the harder zones representing in that case the more persistent upper level for each snceunling lepression position.

The cross-holling structure hows as plainly as it does on exposed surfaces also becanse of the fact that certain streaks ale more perfectly indurated than the intervening one. ant the oljection might well be raised that a history of the kind sugarom abore womld not he expected to de-

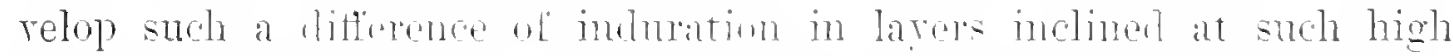

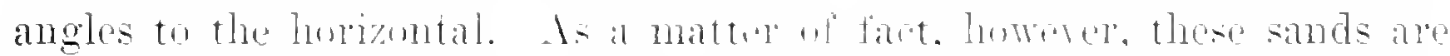

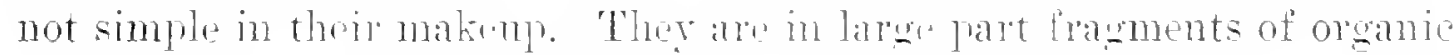

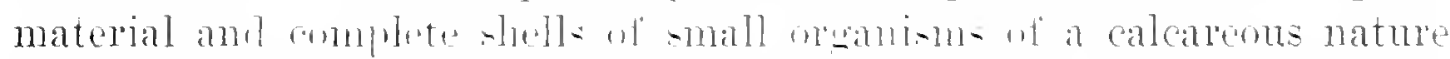

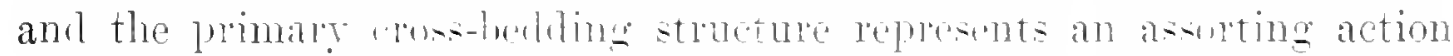
on this mixture of silicalte and carbuale mindal material. It so happens, therefore. that the sucessive structural units aru not necessatily of the same mimeral proportions. and in thr prows of induration. or of binding the grains trgether. rotain streaks riell more rearlily to this

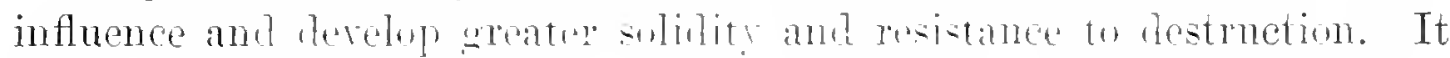
happens, furthermore. from a vintity of rather unusual primary conditions and secondary inthences that hoth a primary and secondary structure of musual prominence and proulial asseiation are dereloped in the San Juan formatim.

\section{SPECIAL RELIEF FEATCRES}

\section{Playas}

The flat areas alony the coatst maroin which are know as playas are all dereloped at the months of rivers and are essentially allurial deposits of floodplain and delta type. In most cases ther seem to occupr areas that must fommerly have been embarments in the coast. This development is most striking. for example, at the mouth of the Irecibo and of the La Plata aml Loiza rivers. In some cases. lowered. there is no marked embarment and the deposit is more strictly marginal. such. for example, as the Fajaldo Playa at the east end of the island and others on the sonth coast.

\section{Promontories}

In addition to the embarmonts and playas, there are, occasionally, in the intervening spaces, promontories where the rock formations extend into the sea and terminate in cliff forms. These are neither numerous nor are they confined to any particular portion of the island or to any rock formation. They are represented by the most recent of all of the 
formations, esentially a silicitied dune depesit such as that at san .Jum, also by Tertiary limesmo rods. such as that at Quebralillas and at Guanica, or by the still older igneons and chatic series, sude as that at

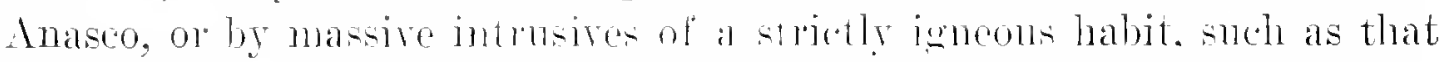
at Mamabo. It would appear trom this that the former ontline of the island mot have heen mone ineware than it is at posent and that the distribution of marginal formations is also not as regulal as las heen repreconted in arlier reports.

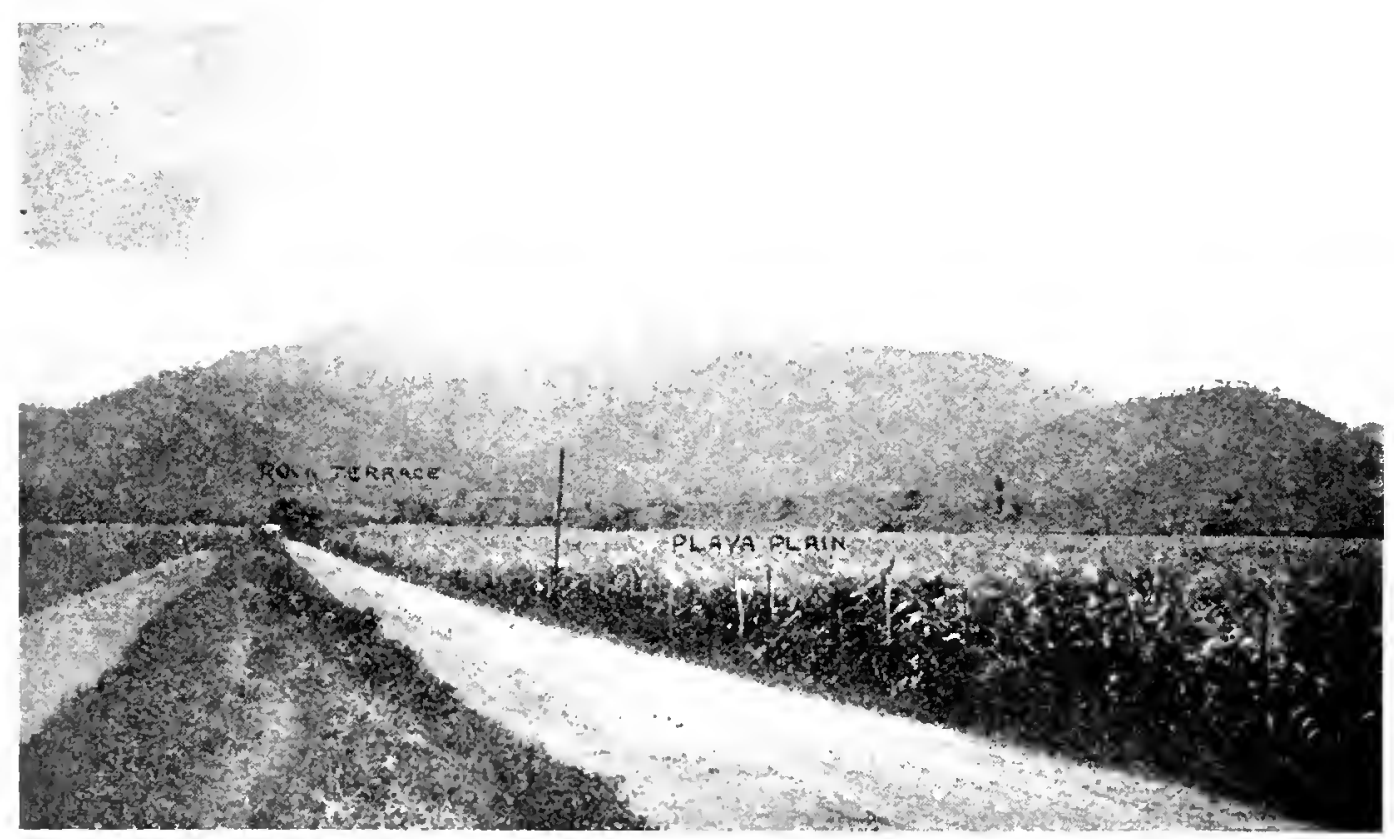

Fic. 16.-Planue plain and marginal temer

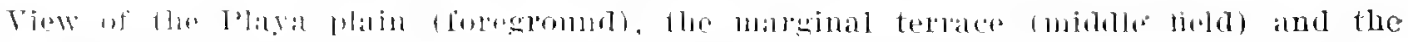

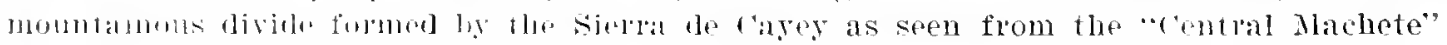

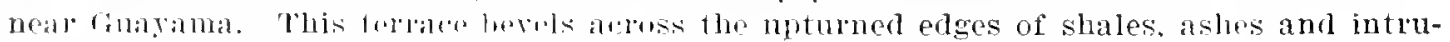

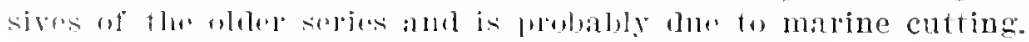

\section{Terraces}

It many places on both sides of the island there are comparatively smowh tracts having the appearane of bordering shelves which represent true turlece. Their location along the sea margin and the comparalimly insonificant devolopment of similar benches along the streams learl one to lelieve that they have an origin connected with the wave action and attack of the sea. This interpretation is supported ly the presun of these terraces along the coastal margin where stream action womlil not seem to luave been able to reach. In any ease, the presence of such toraces, which stand lom 100 to 200 feet above the present sea level, indieate a lormer more submeresed condition, so that the sea or strams. on lwh andined. Wre alile to attempt base-leveling at that ele- 
ration. The presence of grat quantitius of lorghly asoorted gravels clogging some of the rallers of the southerty siele of the island tends to support the same general conclusion. The horring of these leatures on the geolngical history of Porto Rico will he talisu up at another point.

\section{C'uestas}

Both on the north side, for nearly the whole lengh w the ishat, and

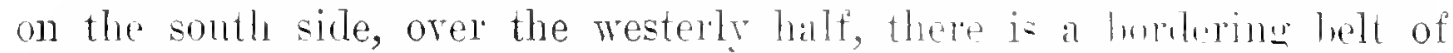
limestom and associated beds that have been tevelow wh an eroled sur-

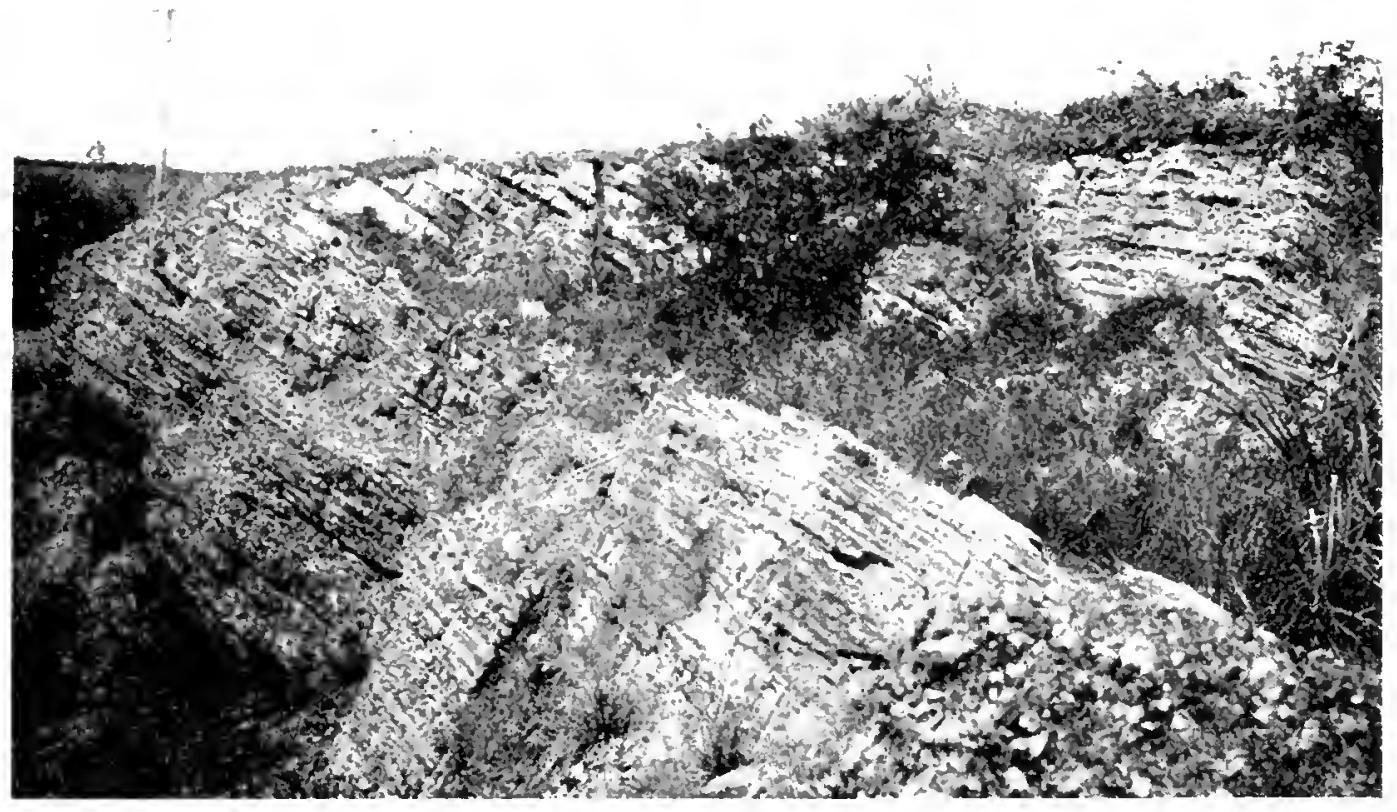

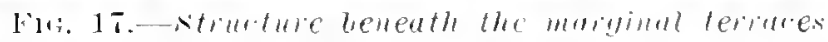

Strongly bedued asl together with associated shales cut ly small likes forming a part of the terrace noal Guarama. These rocks belong to the uble srries and diy into or toward the momtains rather than toward the sear.

face which bereled across the more complex struentes of the older series of formations that formerly made up the mass of the island. These limestone beds are several hundred feet in thickness and dip gently toward the sea. On the inner margin of their present extent toward the interior. especially along the north side of the island. they are abuptly terminated in a very irregular line of modified cliff forms facing toward the prevailingly smoother aml lower ground for some distance toward the interior. For the most purt, this limestone margin is exceedingly rugged and broken. The width of the belt with this ruged rharacter 
varies very much in dillerent parts of the field. Its most striking development is in the district extending from Tao Alto to Aguadilla. In the district extending eastward from San Juan and also in some of the area. on the south side, this nurgin is very much broken and so obseure in some parts as to escape detection. In its best development. however, it is a typical cuesta, formed in the usmal manner by the erosion of a formation representing a recently upliflerl coastal series. The series of formations involved formerly extended inland very much farther than they do now. Only the outer margin remains from the erosional destruction of a series of berk and reels that in former times covered a

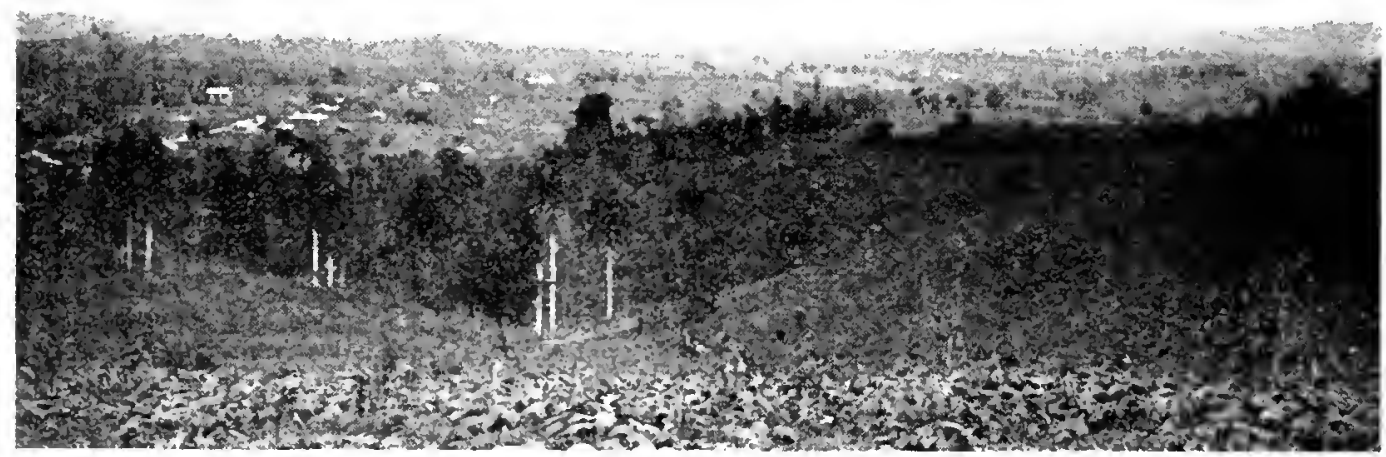

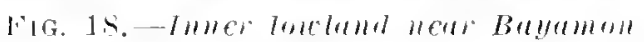

View louking north from the liayamon-Comerio road toward San Juan. showing the munotonous leatures of the lowland belt in the foreground and the combaliatively prominent hill remuants of the Tertiury formation enesta in the background.

large portion of the island. The road rumning from Agnadilla to Noca.

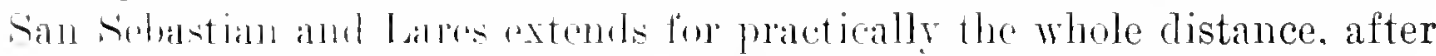
leaving the coast, along the inner lowland at the foot of this euesta or along the clift loming the inface. The same features characterize the surface topography as far east as Corozal. This feature is much less pronomnced on the sonth side of the island.

\section{Peneplain}

Beneath the limestones constituting the cuesta and representing the 'Tertiary series there are, in numerous places, traces of a former plain that representert thr rosults of erosion on locks that had a complex struc- 
ture. Occasional profiles of more distant ridges also show a sky line that suggests the former existence of such a plain, and in favorable localities it can be traced directly to the foot of the limestone cuesta. Ocusional traces are also seen on more mountainous tracts. especially at the west end of the island, near lincon and in the vicinity of Mayagne. At the latter place, these remnants of the old plain are callod mesa. It is the judgment of the writer that these all helong to a single hase-lereling surface or marine-cut platform formed in the period just preceding the derelopment of the Tertiary limestone series. Tudging from beds developed immediately upon this surface. it must lave heen (onnpletert in arly

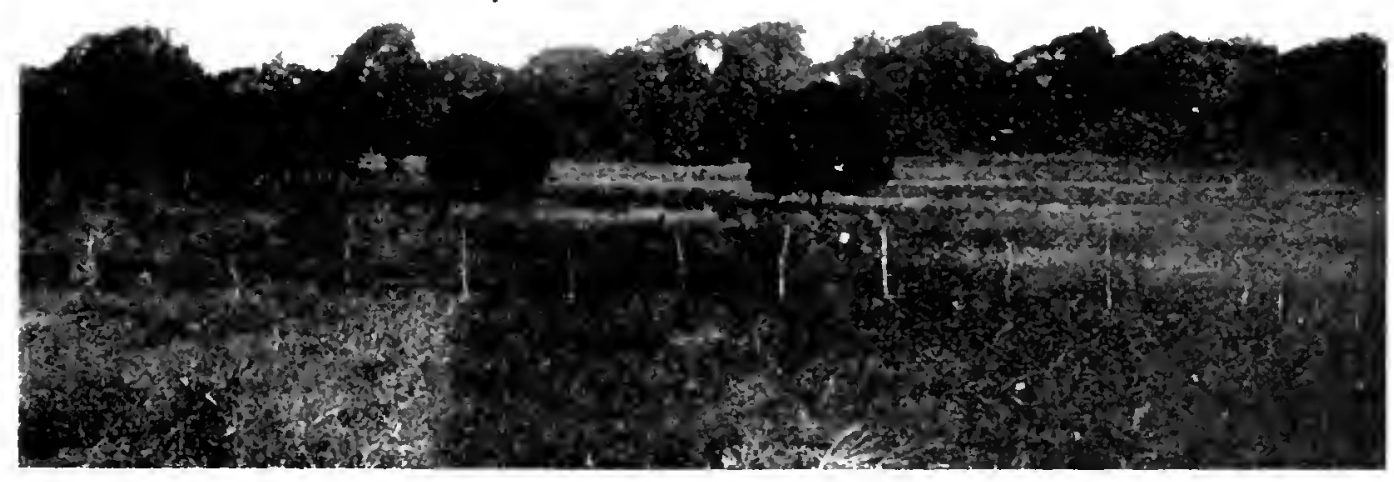

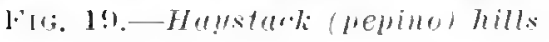

A characteristic view. showing the small solleovered flats and associated haystack hills found in the region of the drecibo tormation. Ihotograph taken on the road between Arecibo and Barceluneta.

Eocene time, and perhaps was eren largely developed in pre-Tertiary time. It may be referesl to as the aly Tertiary base level a peneplain.

There are many minor features giring variety to the surface relief which depend for their particular relations and character on underground structures which are as ret imperfectly understood.

\section{Haystack: Hi7ls}

The most striking topographic teature of the whole island is the remarkable derelopment of small isolated or grouped rugged hills usually rising abruptly above adjacent smooth flat soil-covered areas at rarious levels throughont a broad marginal belt along the morth coast, west of 
San Iuan. 'They comstitute a feature so mmonal that oren the motrained casulal risitor is impressed with thrm.

This feature las been referred to hefore in annertion with the description of the "Youmger sures" of rocks esperially the Irecilo reef limestone formation. In spite of the mmsual appearam presenter ly this distribution of "harstak" hills and intervening fats. their origin is

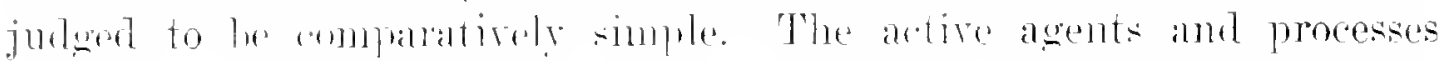
have been the -ame as thene at wht on all other pats of the island. but

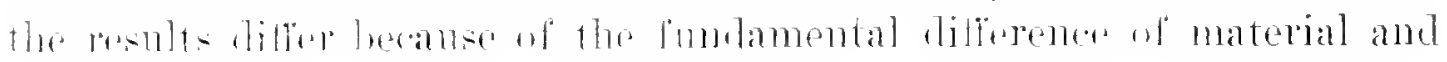

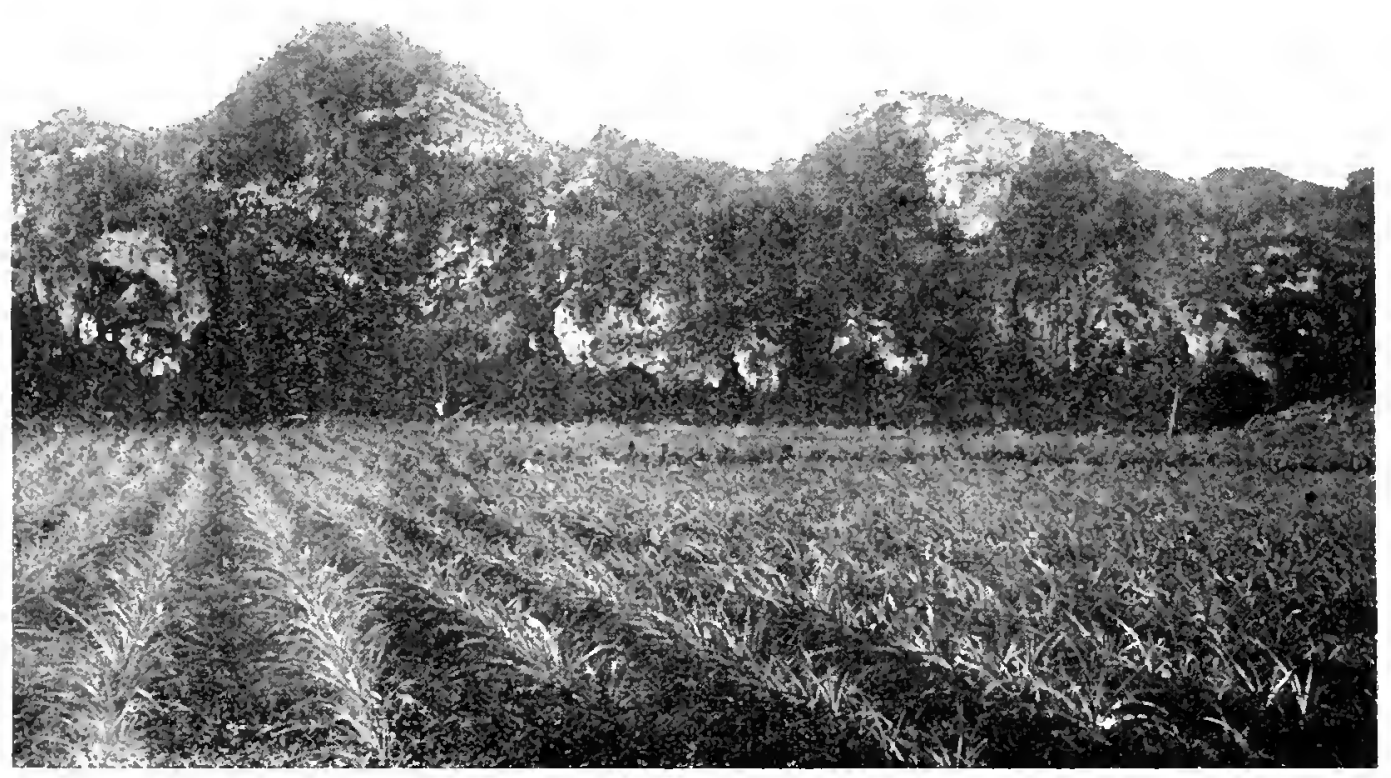

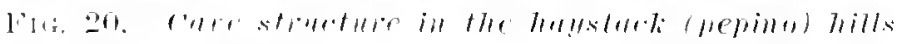

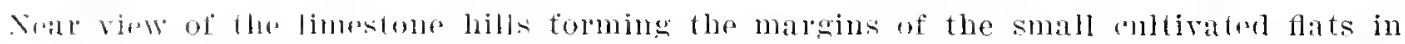
the typical haystack hills distlict. This view shows the cavernous nature of the limestone forming these hills, a strueture that is regalderl as the most signilicant foature and probably the largest fartor in the doveloment of these neculiar rodief forms.

stuctme. Nowhere are these leatures derelopul except where the later

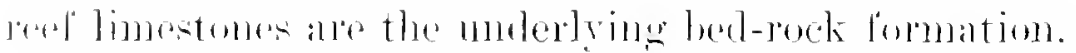

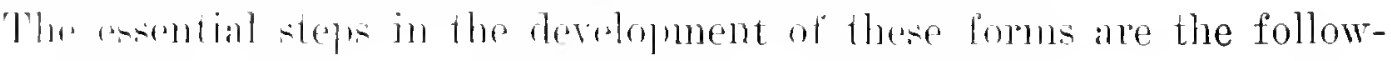
ing:

The lexpl limestones ale not miform in composition or structure. Ther have mone or luse intermixtme of eartly matters which are distrib-

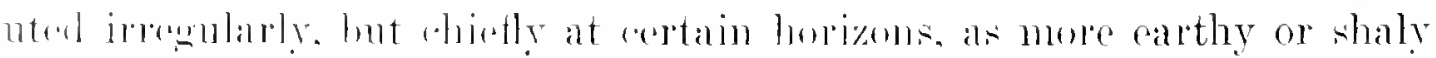

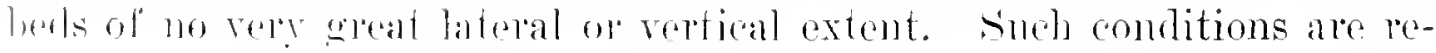


peated at ocasional incerals in suresolve hrizons. As such a series is

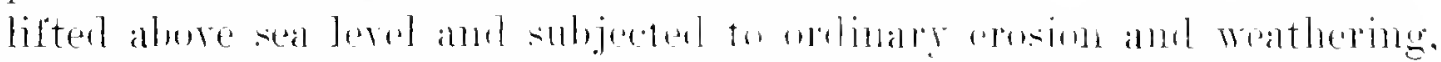
the tendency is. (a) for the purre and more missive reel limestones to be

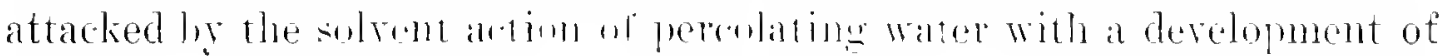

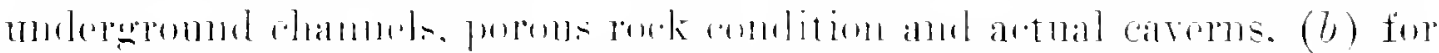

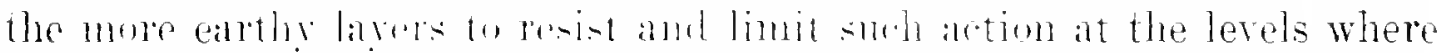

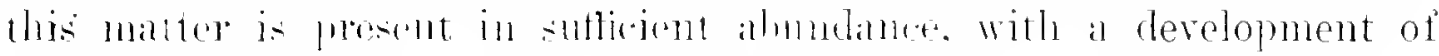

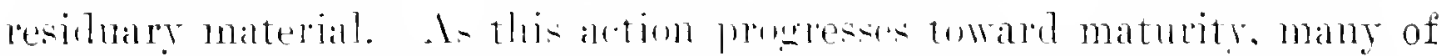

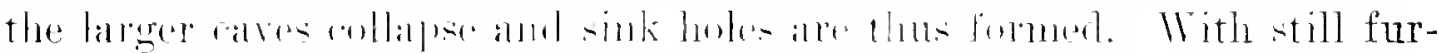

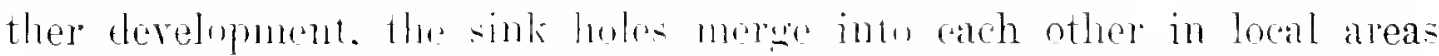

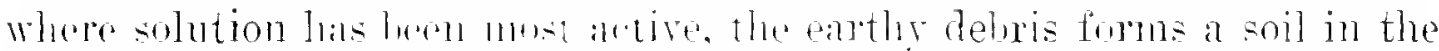

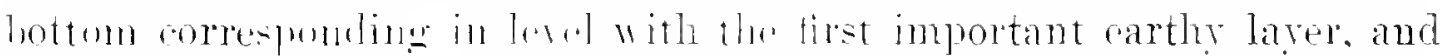

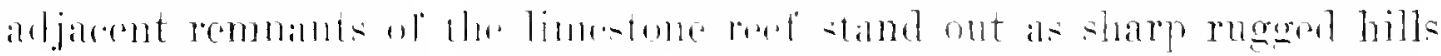

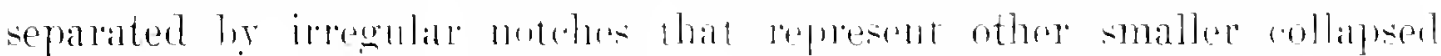

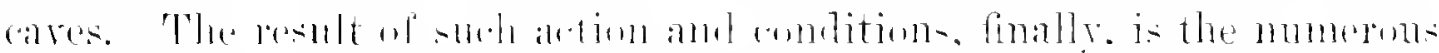

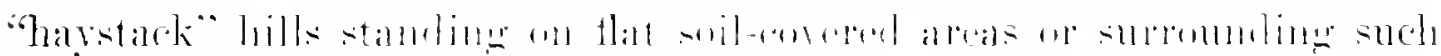
aroas as if ther were just set hown as bmohes on this surfare. This le-

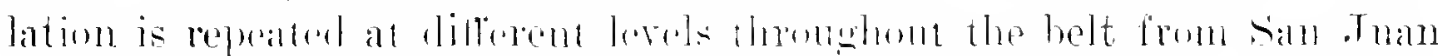

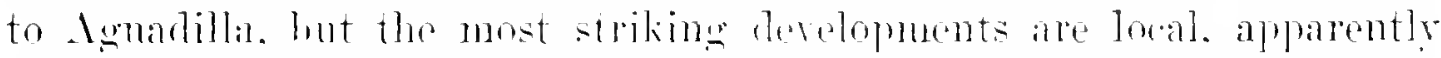
where the structural relations ale just right. and may he seen hest he

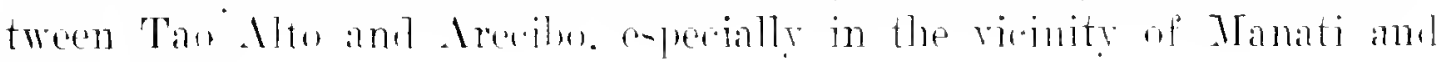
Vega Alta.

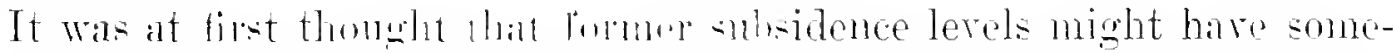
thing to do with establishing the lave tracts. but the observation that these trats stand at rore dillownt lovels in immeriately arjacent districts together with bounition of the structural difference, lead us to give credit to the primary strutural character of the formation itself as the controlling fator in the present distribution. Areording to this explanation, these hills are mepe remuints left from solntion attack on a reef limestone. the hepresins hetreon them reluesonting collapsed carerns. the walls of which may still he seen on the sides of some of the more rngged hills, and the surrombing or intervening tracts are soil-covered and level, chiefly hecanse of the accumulation of earthy material. left behind after remoral of the overlying reef. now halted in its reduction at the first important less soluhle beds.

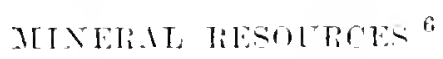

In examination of specimens of minerals and ores in the hands of local prospectors and residents interested in developing mineral resoures.

A A good list or tabulation of the rineral vecurrences of Porto Rico may be found in the article hy H.C. B. Nitze jisted at the close of this paper. 
together with observations made personally, shows that there is consideralsle ranse of minerals and ores. It appears also that considerable attention lias been given in a few ases to local development. There is large varjety shown in a collection of this material and in some cases the speeimens exhibited lonk rery promising indeed. But there is almost no reliable information fouching the puantity or the exact relations or estimates of posible proditahle development. It ran be said, without danger of contradiction, that none of the developments so far mndertaken looking

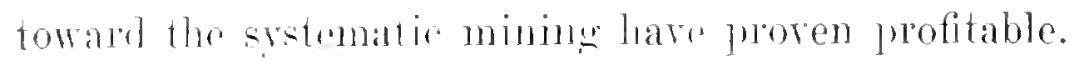

\section{Gold}

(1)ly one enternutise of this kimb secms to furnish any production, and this is the placel mining for gold. Gold washing has heen practiced from the early Spanish vecupancy to the present time, and it is not at all a rale thing to see several nen digging in the strean gravels for the

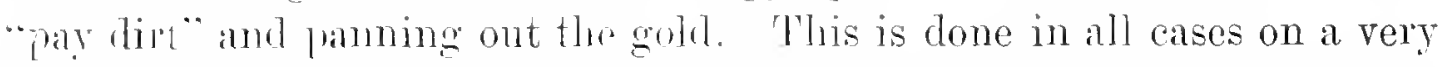
small sale and with the aid of the simplest eqnipment, and the returns appear to bre very moderate. It is chaned that in former times a muels more elabuate systrm of working such leposits was in operation mondel the Spranish rowime, aml. accorting to historical statements, they were comsirlued protitable. More recently, there has been at least one attempt near (orozal to develop this kind of wround by the use of modern appliances, hut the phant has been allowed to go to entire ruin. The only places whre actual placer washing was seen in progress was three miles soutl of corozal and on the Salma rivel near Lmquillo. Near Corozal. also, smme work has bren done in an attempt to discover the veins or lode which may have furnisherl the placel gold. There are sereral pits. frenches and shafts, in some of which quartzose stringers were seen which appear to fulfill the requirements of a somre of smpjly. Some free gold Was foum in paming a little of the weathered material at one of these spots. There is littlo douht lut that these veinlets or stringers, which we numerous at one of the cuts. are in part the somres of the placer wold of this locality. But at no place examined was there to be seen any" "roin" of apparent consequence or any structure suggesting the comse or extent of the mineralization. Of course the rather mixed state represater ly tho residuary matter. seen almost everywere at the surface. dues not lend itsolf reatily to the trabeing of veins, and it may therefore happen that conditions would prove, after thorongh exploration, to be hertur pluan the first lupef examination indieated. There are said to be some old abandoned workings dating back to Spanish conquest times at 
the same locality, but such eridences are very obsore and would seem at best to have very little bearing on present prospects.

\section{ropper}

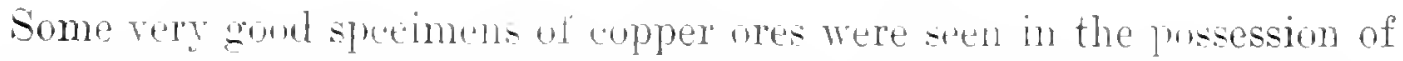
Mr. Henry [1. Nayre. of Gumal, who assured us that there were several localities representerl in the collection and that in 110 eare hall the real value of the recurrenow leren determined. It was understond that exami-

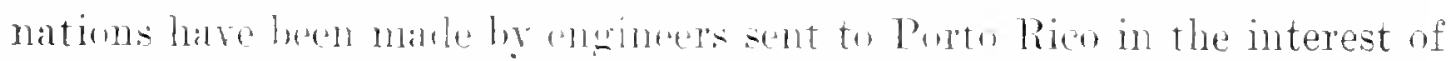

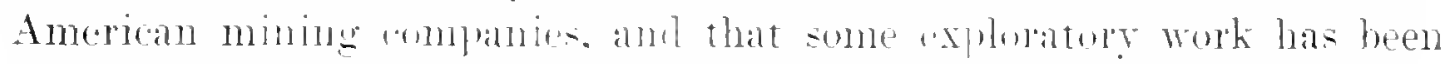
carried on by Porto Rican ampanies or groups of individuals. but so far as known there is at the prosent time no leveloment work being con-

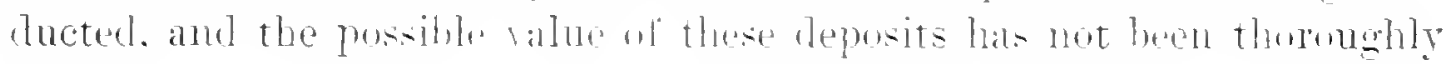
proren.

\section{Zine: Lead and Silere}

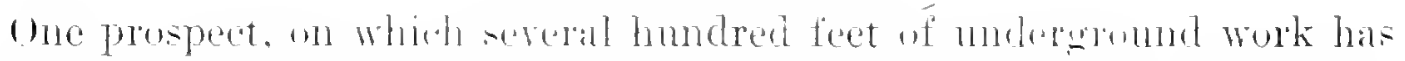
been done. Was visited at barrio del came in the sierra de Cayer, on land owned hy Pablo liagues. several miles northwest of limayama. The country rock is ohielly ambsitic tuffs cut ly porphyritic intrusives. A

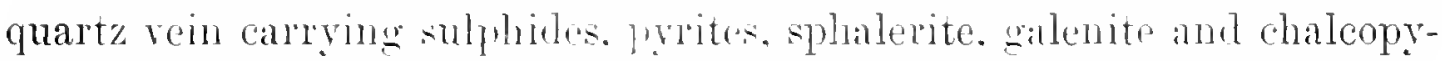
rite has been followed and thela is some ore an the llump. 'The vein varses from a mere stratk to a wilth of two feet. The mineratization is irregular and the values are sald to be chietly in leart and silver. The second-class ore is astentially mineralized tull. The expluratory work has been done in laree pall on siele slips and streak suite ontside of the vein proper. In all of this sile work, there was alparently no new mineral-bearing gromed discovered. The first-grade ore is heary and the distribution of values is not determiner. There is no dombt of the existence of a real vein or of the ore in this case, but there is need of more intelligent exploratory development along the vein proper, together with a study of the possibilitics of separating the chief ralues by some sort of milling operation, before a reliable conclusion could be reacher as to possibility of working the deposit as a mine.

\section{Iron}

One magnetic iron prospect was risited. This occurrence is on the divide about ten kilometers west of Naguabo. It is reached by driving out on the road liom Naguabo toward Torres to about this distance and then taking saddle lurses to the divide, a distance of about two kilometers southwart. On the experlition we were accompanied hy Mr. Arturo Gallarilo. . Tr.. Alcalde Municipal of Naguabo. 


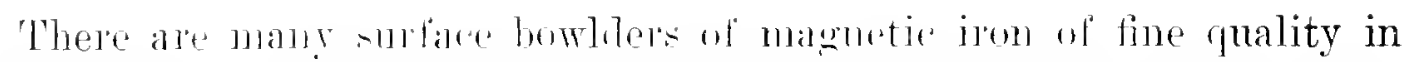
this ricinits. I littr mulergumel working is evident at one point but this is 13 w alvel in. Surlace observations. togethes with a few magnetic

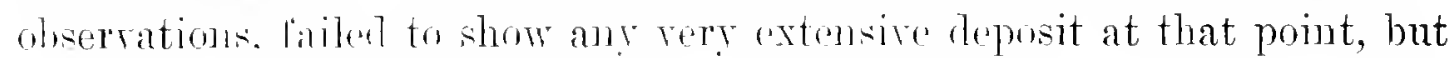
the quality appeats to be gond in irom content. 'The ore carries a little copper and is assuriatul with an igllous rock essentially andesitic in composition. It combl he traced with a lair legree of certainty about filty feet east mul west just bulow the crest ol the ridge. Considering the associations at this place it seems necsisury to conchule that the ore is igneous in origin and that it frohably acompandes one of the porphyrite intusives. Othre mouremces of similar ores were mentioned to us in this same resion. hat none were visiterl.

\section{Coul and Oil}

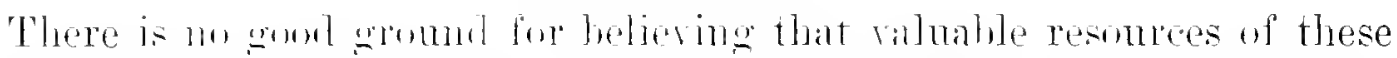
punlucts exist in Porto Rico. Sume prospecting for them is carried on. howerer. in a desultruy way. The only hasis for the hope of finding coal is the occurroner of lignite and lignitic material with the shales lying at tho base of the vomuger series of rock formations. below the Arecibo limestone member. Tignitic material was secu in these shales near Laies, anc similar or better material has been reported from near San Sebastian. From what has been seen. these seems to be no promise of rery vahable deposits of this kiud. The structure is simple and a very little exploratory work chone in a systematic manner would determine the probable ralne of erery occurpence known. There is no promise at all of such content in the older series.

No oil intications were observed. The only formation to be considered in investigating the prospect of oil is also the liasal shales of the younger scopies.

\section{Limeroct:}

I particularly porous. wannlar and uniform limerock is ohtaincel from thre -mall istant. Teacos, just off the northeast coast, and is usen in sugar refining at the Cuntral, owned by the Bird bothers, at Fajardo. The rock is neanic. lowes y forminiferat, and is probably structurally of the same wigin as the fan Inan hme sant deposits,-comparatively leeent. Such

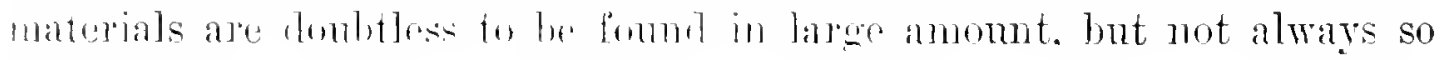
pure and so uniform in quality and structure. Limestone suitable for lime lumbing or for coment mixtme is certainly not rare. Limestone of a puality that womld permit its nes in structural work is also found at

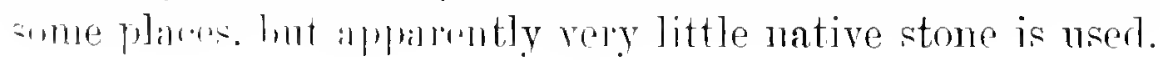




\section{Guano}

Bat guano is found in some of the cires in suffieient amount to be a source of local fertilizer.

\section{Poart Metal}

Several kinds of stone were secn used extensively in road improvements. The particular variety used deponds larwely on the local supply, but the most common are the Arecibr limestone and the massive srenite and granite purplyry. There is no lack of these as well as other types suitable for such use.

'There ale other mineral substanees that will invite investigation, but no others camb molu the witers personal observation and no facts regarding them are in hand.

Jort SIllidia

Thermal springs are known in the rieinity of Coamo. Julging from their location and apparent relation to other physical leatures, they are believed to lie along a lault wakmess. The district is also one ol comparatively late ignems atir ity, and this. complen with the other factors, leads to the suspiciom that the springs are directly commected with the dying igneons alctivity and may actually reperent jucnile waters.

At Coamo. springs Hotel one of these springs has heen developed and comtrolled for commeredal puppes. The water is hot as it comes ont of the side ol a small ravine and rums down ored the slope. which is covered to a moderate extent with deposit from these waters. The immediate bed rock is not well exposed, but it is julgerl to be either a tuff or an igneous complex and the fiold relations in the vicinity show that there is a thick series of beds both above and below. No doubt critical field study could determine the actual relations with comsilerable certainty.

An analysis of these waters, furnisher by the proprietor of the springs and made at the agricultural experiment station at Mavagnez, is as follows:

$$
\text { Fired elements per litie of ruter }
$$

Free arbonic acid....................... 0.01296

Sulphate of lime....................... 0.79902

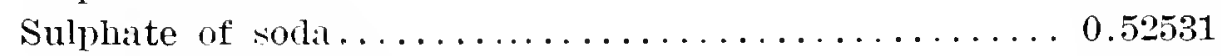

Chloride of potassium ..................... 0.00081

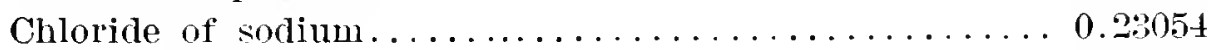

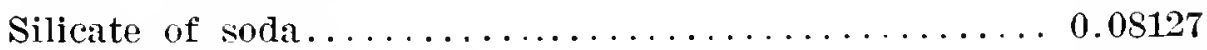

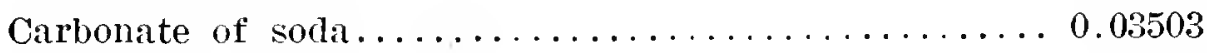

Carbonate of iron..................... 0.01114

Total............................ $1.6 \$ 559$ 
Gases in solution per litie of nater at $0^{\circ}$ of temperature and $760 \mathrm{~mm}$. of pressure

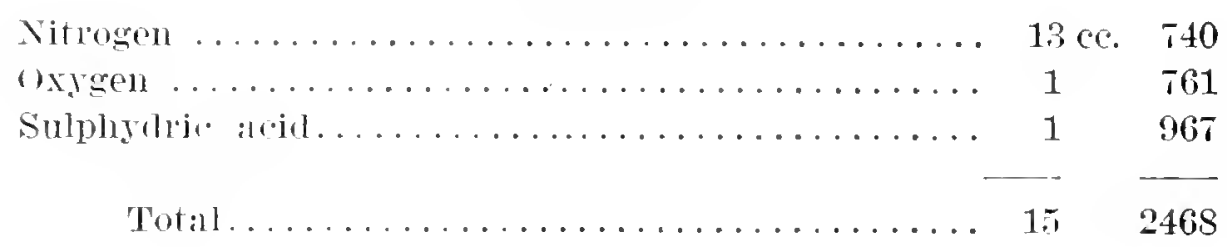

\section{TISTORGAL STATEMENT}

1 complete or even a reasonably full account of the geological history of Porto Rico camnot be written at this stage of the investigations. Such a statement is necessarily the end prodnct or climax of the whole series of studies that are proposed, but it may not be out of place to outline some of the leadiug and most clearly marked steps as a rough sketch or a preliminary attempt.

It the outset, it is well to appreciate that the Island of Porto Rico is weologically young. 'Tluere are no traces, so far as known. of any of the so-called ancient rocks. It is quite true, of comrse, that the older series of formations is largely a voleanic complex whose exact age nay never be accurately determined. but there is no uceurrence of profoundly metamorphosed members or other evidences of great geologic age. Besides, the serics. complex as it is and difficult to nomp into suitalnde divisions as it may be, molonbtedly lorms a very elosely redated sucession of minor formational muits whose mpermost members ale leterminable als to age with reasomable aceuracy. It would appeal also lirom the mature of the reposits and their structural relations that the accmmulation must have been, forl the most part, a raphicl process.

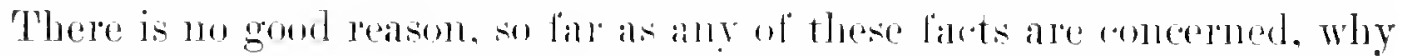
the whole of the "Oldter series" conld not have heren accummlated in a single genlogic perion. The losil molntit of the upper members of this series indicates that this period was the ('retaceoms, as used in the broader sense in geology. Whether or not the older members date back to an immediately preceling time cammot yet be definitely stated. but whatever there is, is chearly so dosely associatod with the Credaceous heos that they can all be treaterl as a sillgle historical moit.

This earlier period is characterized by volomic and other igneous activity on a very laroe seale. Beds were accumulated both above and below sea lovel. There seem to have been oscillations of level accompanied by rerbrronces of similar hers, and apparently much shifting of the supply ol material aromplanjer ly great variation of character laterally. There is gom evidrux that sueceoding volunic outbursts broke throngh these lwk at many platers. 
An occasional more prominent change of conditions, more or less clearly marked in the structural relation and character of material, mar possibly be used as a hasiz for eporhal sululivision. It is quite clear, however, that there was no profound change uf geologic control throughont the whole of this earlier time.--it was strictly a volcanic period. The succession of disturbances by whoh it was aflected is represented in part by dynamic modifications of the nature of folding. "rushing and fanlting.

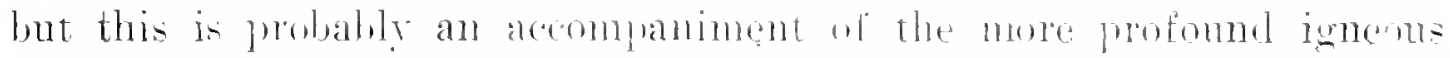
activitios also. and need wot he regaredol as ovidence of any strikingly different comsal prowes. It there were contributory causes of a regional sort controlling the fohling. they are esentially simply superimposed upon or introduced into the larger. more profound and longer contimmed igneous actirities which prevailed both before and after that time.

This long period, eharacterized hy great complexity of formational

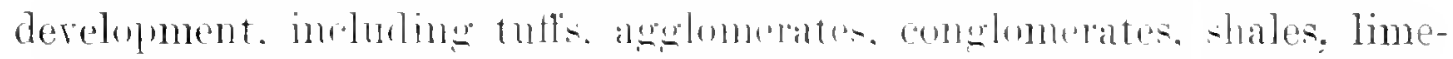
stones and immense numbers of intrusires ol great rariation in size, form and composition, finally came to an end ly the dying out of the volcanic energr, and greater stability of the whole with respect to elevation and subsidence was established. Frosion ant down the exposed formations. the sea attacked the margins and in time most of the projecting momntain mass was redncel near to hast lorel. the sea encroached far onto the former land areas and a new historical thapter was begun.

It is not possible to say, with the data in hand, that the entire island was reduced to a peneplain. or perhaps a conoplain, hut there is good evidence. from the traces still left of former blunation and from the disposition of the remnants of overlying formations still preserved, that the greater part of the present area was worn down to base level and submerged. The process of base leveling was going on before the close of igneous activity and it was continued long enough to bevel across rocks of all sorts with marked snccess, but there is no necessity for regarding it as a verr long geological time.

As erosion proceeded, sediments were deposited unconformably around the margins of the island of that time and perhaps also in some of the marginal vallers above sea level. 'These constitute the earliest shale beds of the "Yomnger series" and are bolicred to be of Encene age. Ther are at least early Tertiary. Where more simple marine conditions came into control, as would happen when submergence or planation had masked or destroyed the more elevated sources of supply, the deposits became almost wholly reef limestones and shell limestones. with only minor amounts of strictly detrital material irregular? y distributed. This gave a succession of somewhat irregular beds which are abundantly supplied with organic 
lemains and which heal evilener of the rontinded depression favorable for the growth of these acemmulations for a considerable part of Tertiary time. There is some sugerstion in the relations shown in the eastern portion of the island that this and wa not wholly submerged and that differential subsidence gave to this nution less prominent development of the heary. massion limsetmm heds.

In later 'Tertiary time there was makn reëmergence from the sea, accompanied ly warping so that the bater limestones and reefs were lifted

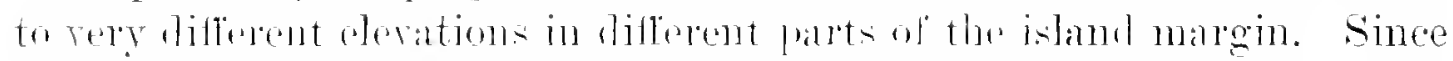
that event. the whole has been again subjected to erosional attack of the sea, and to wind work, with the result as now scen in the phrsical features. The comparatively easily destroyed shales. marls and limestones of the Tertiary series lave been extensively removed. learing only a fringe of these formations along the north coast and a part of the distance along the south roast, and developing all of the topographic forms 'haracteristic of the erosion of emerged coastal deposits, together with some very special forms due to the peculiar makenp and attitude of the rocks themselves.

Since this first emergence there have been minor oscillations also, the recopl of which is observable in marginal teraces, deeply trencher floorphain dopoits. and thoroughly indurated wind deposits of presmmably Thistoren age. Apparently the latest movement has been one of slight emergenee.

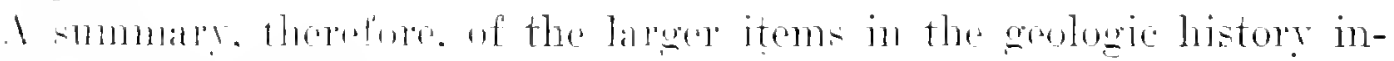
Thetes the following:

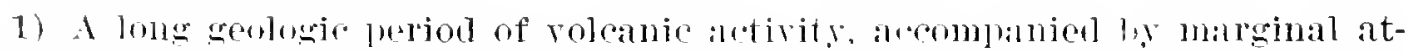

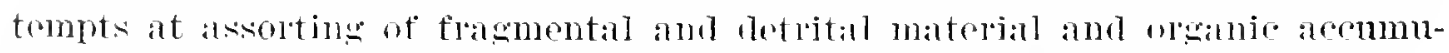
lation disturbed from time to time he renowerl or extended inneous activity.

2) A dying ont of volcanic energy greater stillility of the mass with respect to eleration and sulsidence, and elosional at atek continued long enongh to result in extemled flanation and partial bas lovoling with final extensive submerencente

3) The development of an unconformmblo orelying sories of shiles, reef

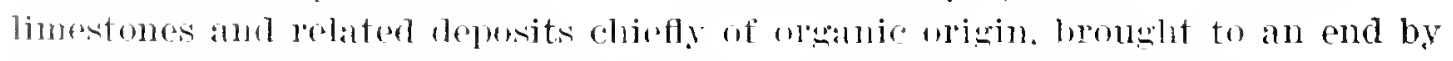

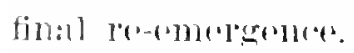

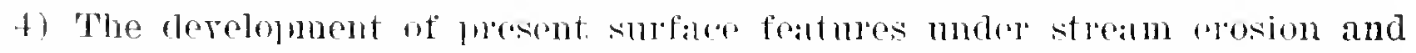

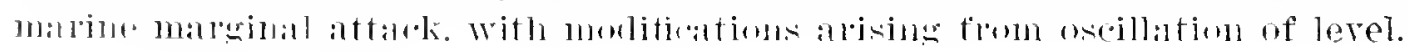

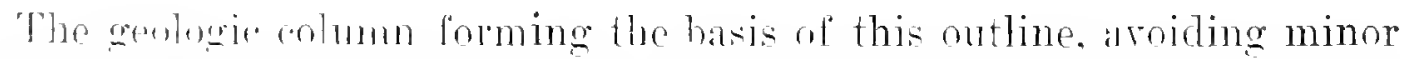
restails that are properly the subject of further study before specifie statement shombl he marto, is as follows: 
Recent allurial depmits.

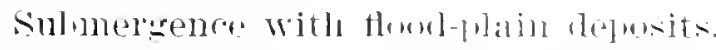

Younget series.

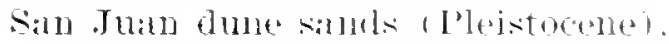

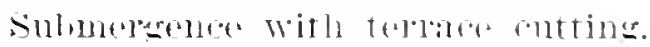

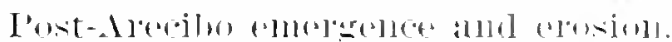

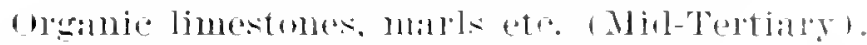

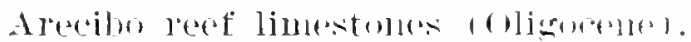

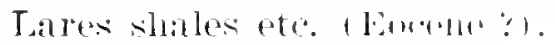

Marked unconformity.

older Series.

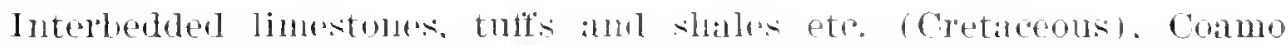

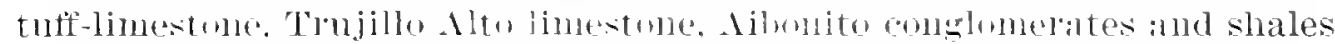
with milly intrusives.

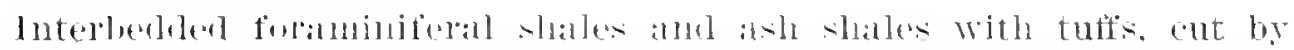

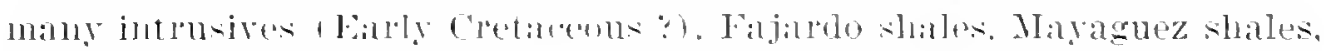

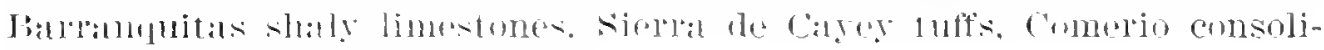

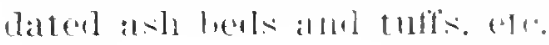

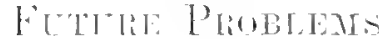

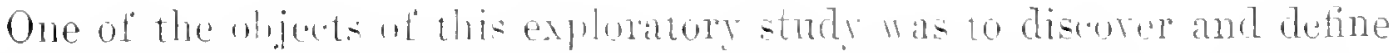
the problems that should he invetigatol by this olganization. It is not suplosed, in mumblating this list, that these corm every posible sulpject of special stmy, hut thry an imlicate the fields in which there is promise of imnediatr and valuablu - rentiti. returms. and at the same time will

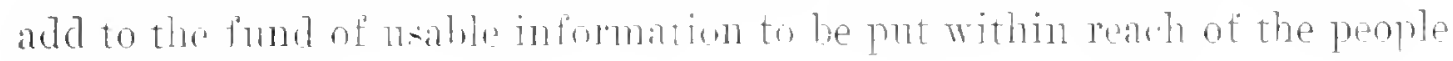
of Porto Rico.

$\operatorname{IBI}=\mathrm{E}$ IIAP

One of the fundanental things at a hasis for all wrots of detailed genlogic work is a gond contour malp. The whole iskand ought to be mappen in the same mamner as in lone in the United States, wing the same quadrangle system. On acount of the density of population. the complexity of structure and relief and the variety of agricultural uses of the soil, the sule should le apluoximately one mile to the inch, or 1:62500, so that these maps could be user as base malps for all sorts of special purposes.

The maps now arailable are chiefly those of the Interior Department of Porto Rico, made to illustrate the rarions reports of the department and representing the progress of public works snch as railways, telegraph and telephone lines and lighwars. On acconnt of the care with which the diflerent classes of roads have been shown, and the general accuracy of locations, these maps are especially useful in the present investigations. One of the most useful is a map of the Bureau of Public Works 
on a scale of approximately inch per mile which has even the kilometer distances along the roards indicated. Tntil some sort of a contour map can be secured. such majs as these will be found eminently serviceable.

Along the south coastal margin within the region of irrigation developments, there has been some special mapping with contours. In no case do they cover mols gromd berond the outer lowland and terace border, and becanse of this limitation they are not so generally nseful for our purpose as the Interior Jepartment maps. 'They are. however, very much mole andute and detailed and for the territory corered are eminently suitalule as lase maps.

\section{GEOL.OGl' MAT}

A geologic map of the island should be one of the results of this series of studies, whether a relief map is secured or not. Such a map of the whole island is necesinily an ultimate rather than an immediate product, but district majs can be mudertaken at once, with no difficulty whatever. These preliminary ristricts can he selected so as to include some of the most promising investigation prohlems in special lines, and both kinds of work can thus he arried on at the same time. This therefore leads Jirect]y to the nex item, which is district studies.

'The only wonlowir ma], thus far attempterl is that by R. 'T. Hill.

\section{DISTIICT STUDIES}

It is possible now to select areas which are known to contain geologic features of special interest and significanco. and it will generally be conrenient, il not indred necessary, for the investigator to make a detailed wenlogic map as a secure fonndation for his special studies. One of these is the Coamo springs District, which may be made large enough to extend from the Descalabrado river on the west. to Salinas on the cast, and reach as far north as Aibonito. It will include as leatures of special importance for investigation. in addition to the mapping. the hot springs, the rreat ronglomerate sories, one of the laser of the great volcanic vent complexes. the genetic history and lorizon of the Commo limestone which is a striking mixture of voleanic and organic matters, the high floodplain deposits of the stream valleys and their hearing on late geologic history, amel rertain physographic sturties ennected with the coastal terraces. This district promises, as can be seen. an musually large range of topics inviting special study. all of which will be illmminating to forther development of the geologic surrey of the island.

Inother district of equal promise in a very different manner is on the north eoast extending from the Quebradillas to the Arecibo river and 
reaching from the sea to Lares so as to includt a strip of the older complex rock series berond the inner margin of the Tertiary series of reef limestones and shales which constitute the greater part of the bed rock of the area. Beside the mapping and detail of structural relations. this district presents the best opportunity to investigate the question of exact age of the hasal heds of the Tertiary series, the transition from lignitie shales of perhaps flesh water alluvial oricin to massive limestones of reef type, a subdivision of the Tertiary series. the meaning of the thinning out and disappeirance of the Lares shales toward the east, and a paleon. tologic study of the heds. all of which are fundanental in any additional study of othwristricts ( ontaining the Tertiary rocks. There are besides good opportumitis to study the meaning of the high terrace-like shelf coming abruptly to the sea at Queloradillas river and the meaning of the deep embarments now oreupied hy such playas as that at Areciho. This is also one of the hest localities for a detailed study of the structural and petrographic parures of the San . man formation as well as the hehavior of modern lune sands alnng the present coast.

Another listrict of still different features. and giving foundation for special studies of quite a different bearing. is that lying between Caguas and the Caribhean sea and perhaps extending as far eastward as Naguaho. This will inchur. the largest massive ignems unit in the whole island and promises information bearing upon magmatic differentiation, origin of the magnetic ilon ores. relation of the rreat intrusire masses to the other igneous repuentatives, petrographie range of the igneoms rocks, and maroinal metamorphic or other effects. - studies funlamental in a final statement of the igmeous history of the island.

There are other districts which hare special prohbms anonciated with the regular areal goologic work, hut these are sufficient to indicate the range of such district studies and their variety.

Certain special investigations are of a sort requiring comparison and summary of many difforent localities, and for these it will not be wise to handicap the investigator by limiting work to a single district. Some of these are suggester helow.

\section{REEF-BIIIDING ORGANISMS}

The lmestones of Porto Ricn are remarkable for the great prominence of algie and corals and other closely associated oroanisms lending themselves to the construction of reefs and accompanying deposits. These forms belong to practically ererr limestone formation of both the older and the yomnger series except those most closely related to the shales. It is a study requiring the training of a specialist in such lines. 


\section{IALEONTOLOGL}

The total orwuis wntent is much greater than is intended to be included muler "Rert-huilding organisms." Thore are immense numbers of splendidly preserved fossil species of oromisms belonging especially to the Tertiary saries. Probalyly a strat many are new to science. There are probalny few places in America or within territory belonging to the Tnited States where the marine Tertiary sucession is of more promice than in Porto Rico. This problem or line of investigation is closely related to the next topie. that of 'Tertial'y subdivision.

TERTIARY SITHTIVISION

I fambal and structural smmmary will naturally loat to the establishing of suludicions and the dotomination of horizons in the rounger series of rowk whumating in a statement of the complete Tertiary history of the island.

\section{SAN TUAN FORMATION}

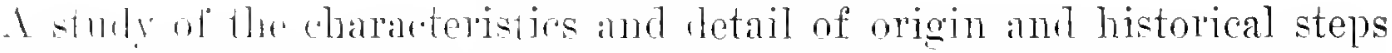
assuciatel with the Plejstocene fossil dnne sands. referred to as the San Juan formation, is another mohlem.

\section{GEDOTISION OF PRE-TERTIARY COMPLEX}

A Mirenssion of this kind is one that will propery follow upon the complevion of areal work in serral of the typocal districts. It is. however, one that will necessitate invesigations throughont the interior of the istand. and will inchude a smmmary of the characteristics of all of the prominent loral formations. A grouping and correlation can un doubt he mante in dre time.

\section{MINERAL, IIESOURCES}

On account of the interest taken by the people of Porto Rir.o in the question of possible mineral resonves. it is desirable to mndertake an investigation of the kinds of products, their origin, distribution and probable eronomic value. In connection with this, because of the small amomnt of exploratory work that has been done, it would be especially nseful if sngestions were made at the same time abont the methods of exploratory derelopmont and the people cantioned concerning wasteful methods. This work shonld he done so as to cover the whole range of mineral possibilitios in the island resardless of location. There are known doposits uf coppor. irno, anold, lead, silser and zine among the 
metals as well as a number of non-metallic products. But in no case is the real ralue, or the probable extent or the geological relation, known sufficiently well at the present time to serve as a basis for a discussion. This should be one of the first undertakings of this survey, both because of the fact that its value is fully alproreiated by the people of Torto Rico and because its conclusions do not materially depend upon the other inrestigations or mapping progress.

\section{PETROGRAPHY}

On account of the great number of igneous rock occurrences and the rery great variety that is certain to be shown in quality and minor petrographic character. and hecanse of the consilerable range in composition already known to characterize the intrusires, there would seem to he an ample and promising field in this line for a special investigation. It is possihle that some genetic relationship is exhihited in the ristribntion of these variations and that a thorough omprehensive study would throw some light on the more obscure problems ronnected with the genesis of igneous rocks. 'This is a problem that can be taken up at any time, and that need not be regarded as dependent upon special district studies, although it is evident that the finishing of work on certain districts would facilitate a study of this kind.

\section{PHYSIOGRAPHY}

Enough is known of the physiographic features and their meaning to appreciate that a great deal of the detail of the later geologic history of the island is more or less intimately bound up in the phrsiographic development. The broader or larger physiographic features have already been suggested, lut there are certainly many details, some of which may well be of much significance in understanding the geologic history, which will require the special attention of a trained phrsiographer. Porto Rico is a unit of geologic history, of geologic structure and of physiographic form. Each is of sufficient complexity and unity to be made independent subjects of investigation.

THERMAL WATERS

The hot springs in the vicinity of Coamo Springs suggest from their situation and reported composition the possibility of heing representatives of juvenile waters. It is believed that a study, planned especially to investigate the origin and character of these waters, together with such others as may exist, would be a very suitable special investigation. On 


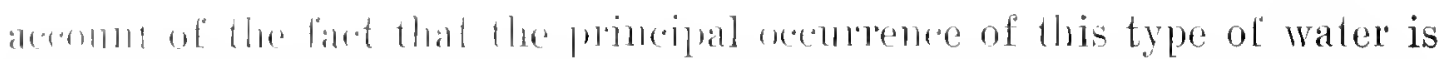

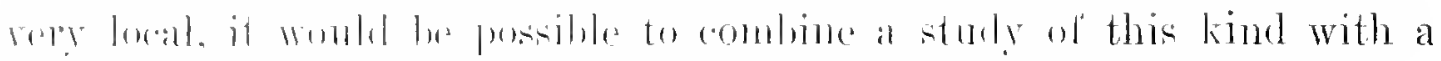
distret study stede as bas leon refored to in a preceding paragraph.

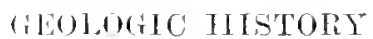

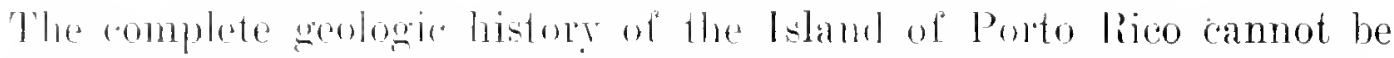
writen motil all of these and perhaps other mole special investigations

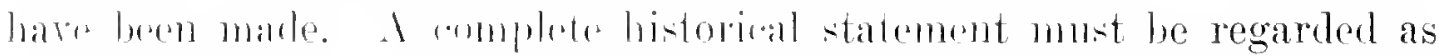

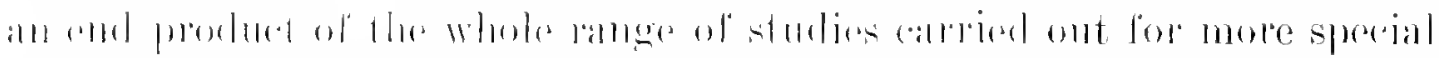

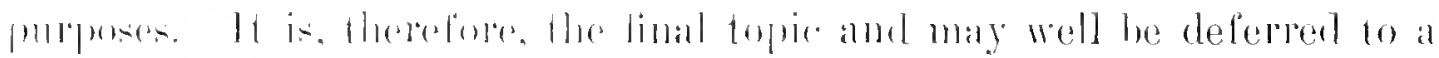

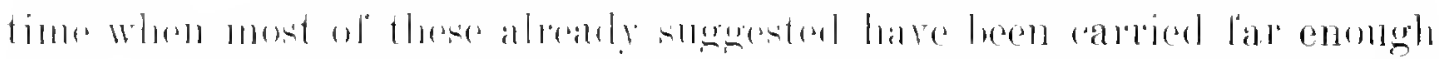

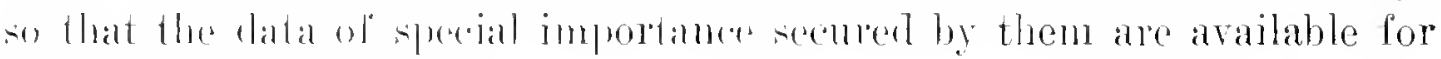
this womolal smmmaly.

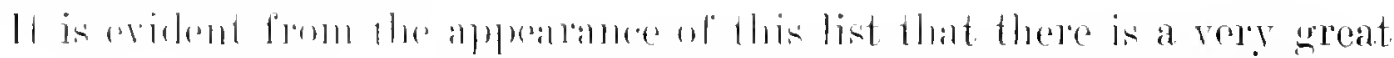

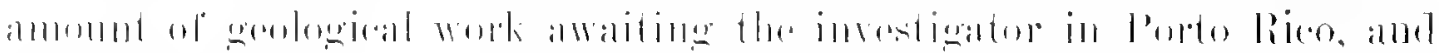

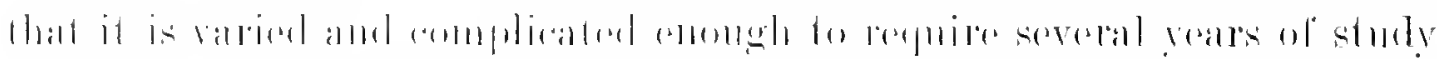

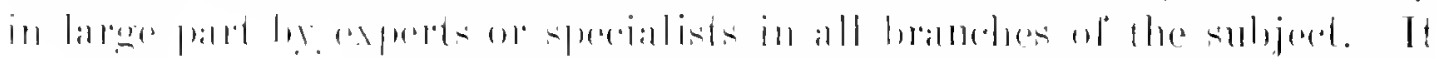

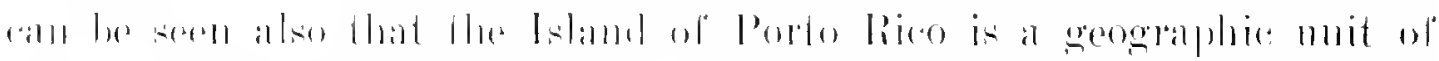

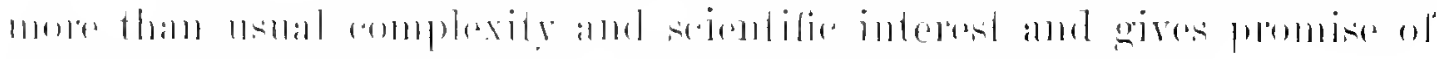

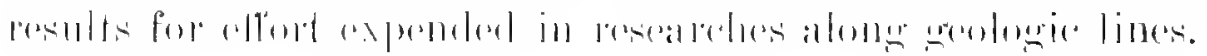

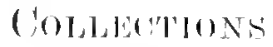

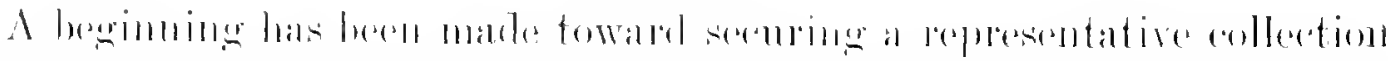

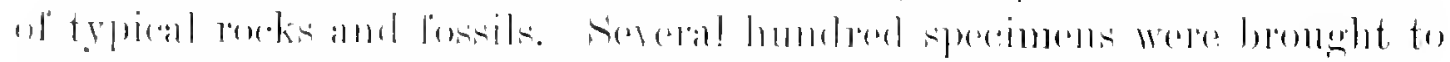

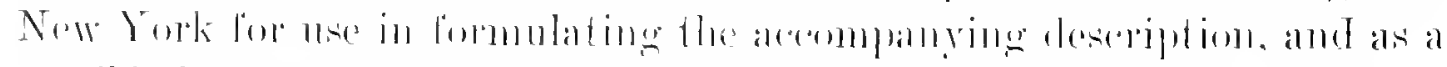

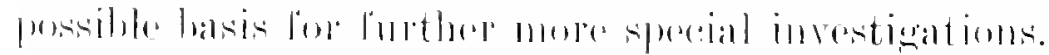

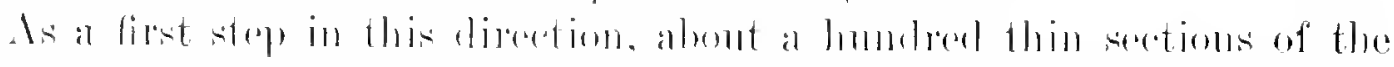

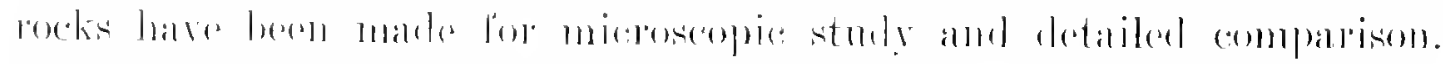

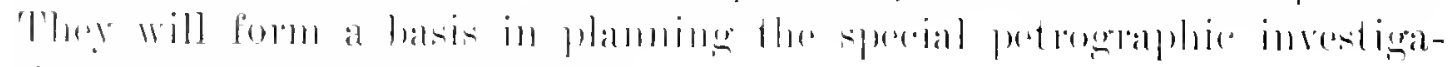

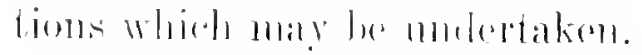

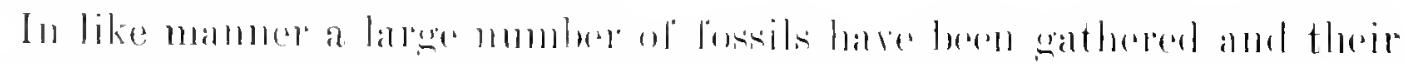

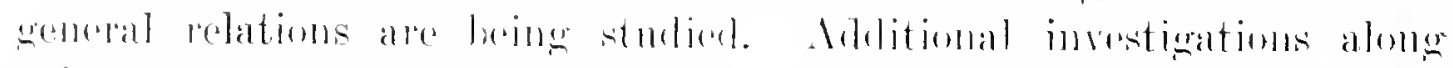

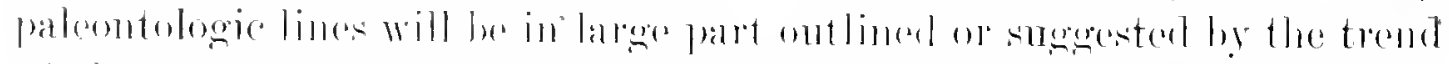

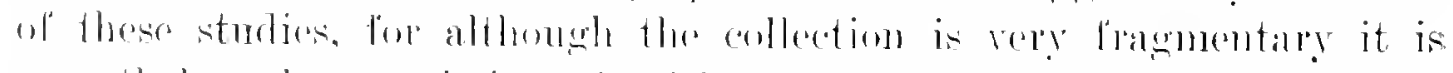

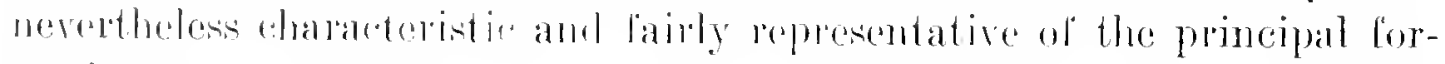
mations.

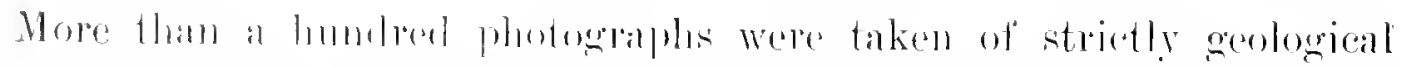
suljects illustration typical physiographie leaturese structural detail of rock formations, structural relations, ete. These are all skitably labeled and form the beginning of a rollection of jllustrations af Porto Rican 


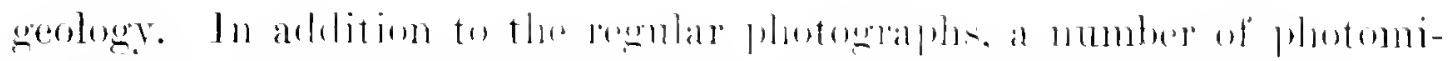

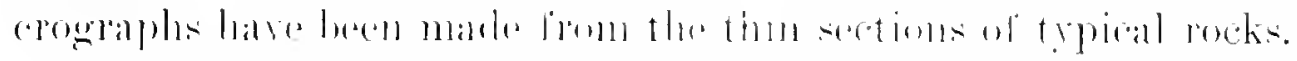

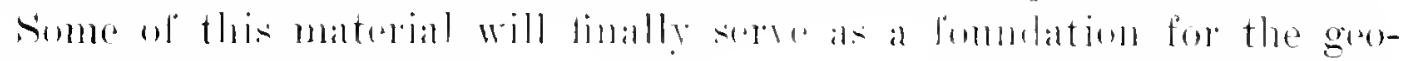

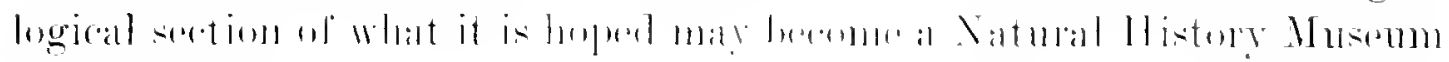
of Porte licas.

\section{LLUSTlAthos}

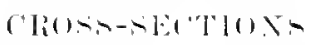

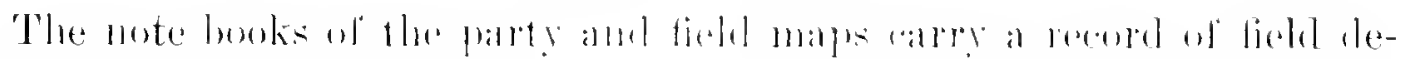

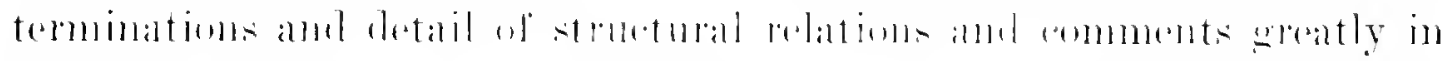

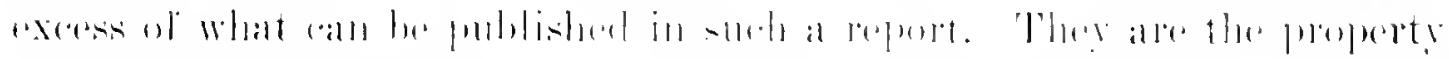

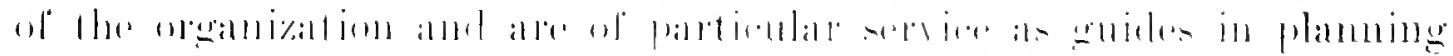

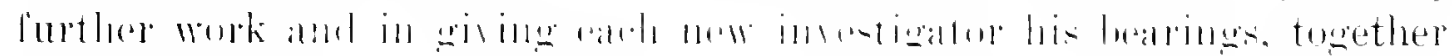

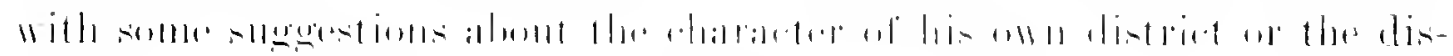

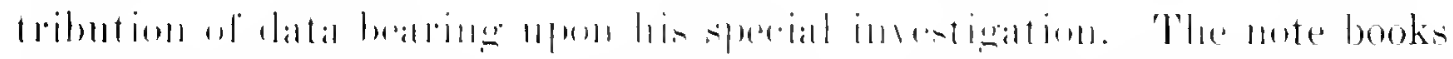

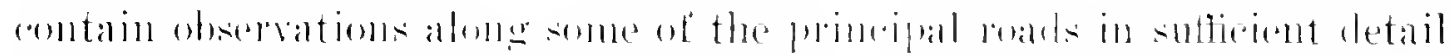

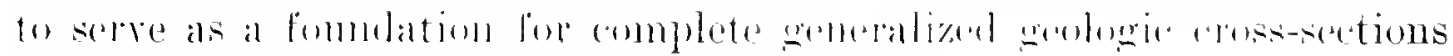
ol the istambl on two esperially important lines.

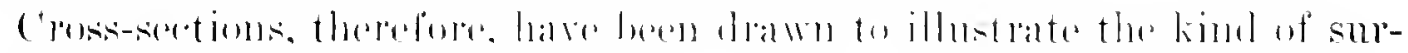

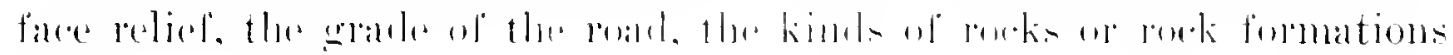

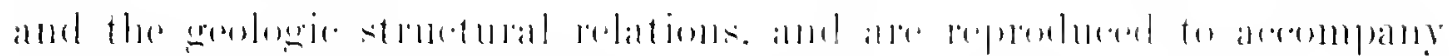

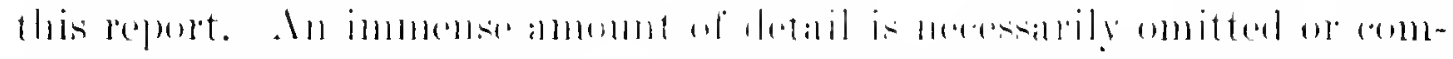

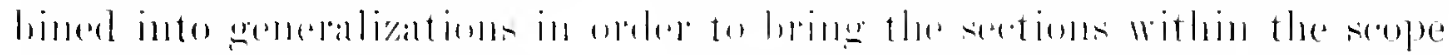

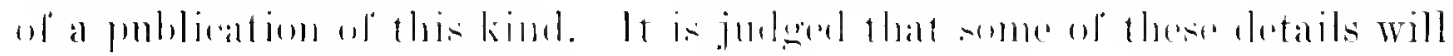

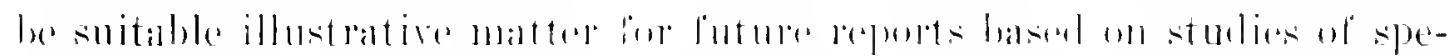

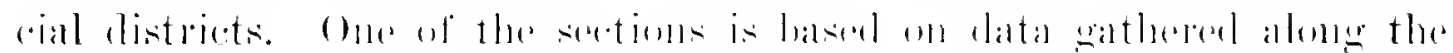

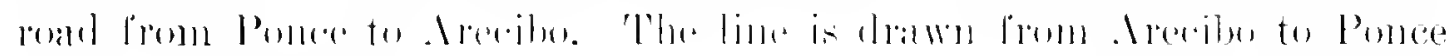

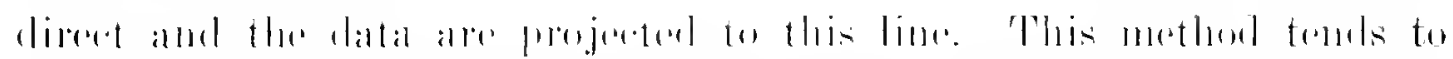

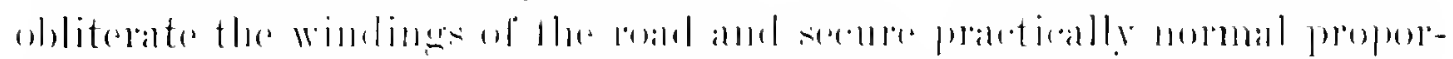

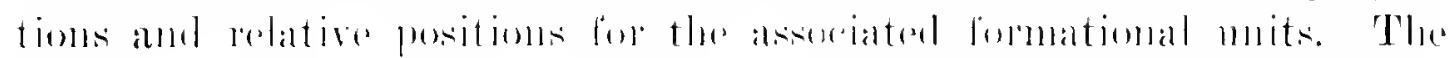

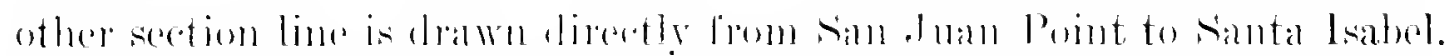

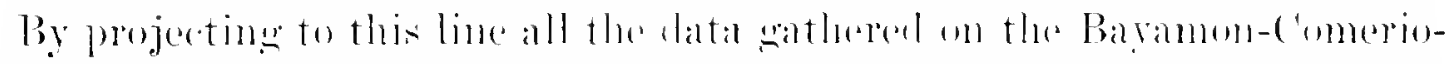

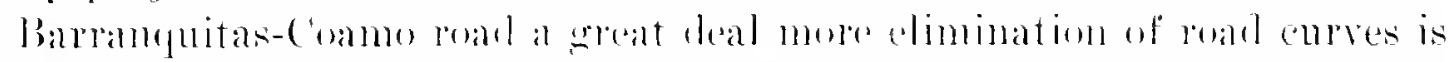
areomplished tham in the other seations. and it makes the garales of the road look somenlat almormal ly reason of this shortening of roald distance of certain larese cures, but on the whole the relations are shown

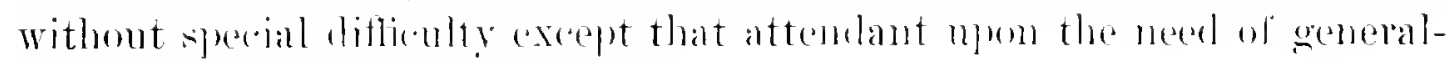
izing the minor struetural detail. 
MAPS

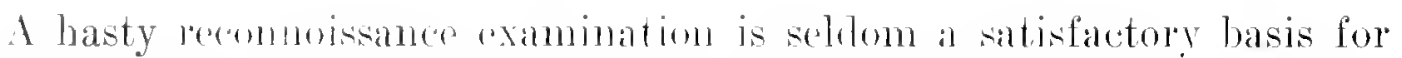
an areal map. 'This is quite truo of the present infostigation. On this

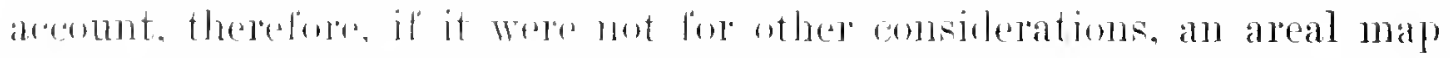

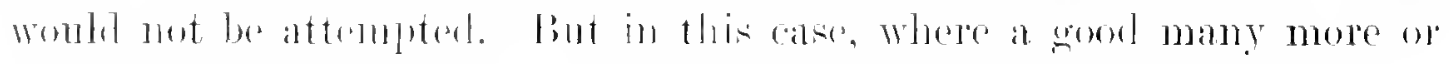
losim independent sperial investigations are to lo calried on in which a reasonably accurate geological map will prove decileslly hedpul, there is suffieient exense lon presenting a resommissince map. An earlier map) of this kind prepared by R. T. 1lill was mate moler conditions so much less favorable for travel, and seems to have hecur constructed in some particulars with so monch loss opportunity for observing the actual conditions in certain areas, that an cutirely new map is heliever to bo the better

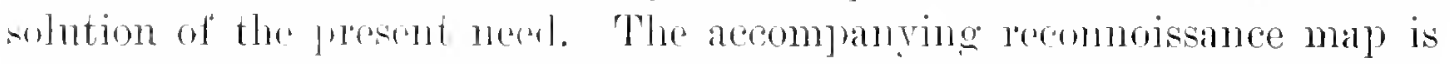
intended, therelore as a comperient guide or lowation map for subsequent more special imsestigations, and it is rxperted to low wholly replaced by one of much more retail and greater acentary as a final product of this survey.

\section{ACTNOWLEDGMENTS}

The members of this experition have appreciaten the very material help, the sound advion and uneful sugestions given by the offeials of the govermment of Pordo libo, and are incleded to Governor Teager for his very practical atil in making alrangements for the field work and for his live interest in these inventigations: fo Colonel shanton, chief of the Insular Police, for his willingness to wire introductions to men acquainted with special mineral lowalities and for his precautions to insmre protection against mmerosialy lelays; to Mr. Wheceler, of the Interior Department, for assistunce in securing suitallo majs as a basis for travel and notes; to $\mathrm{Mr}_{\mathrm{r}}$. Bommer, the Lmbitor. lor lacilitating the settlement of aecounts; to 1)r. Tippitt, ol the Burean of sanitation, for information

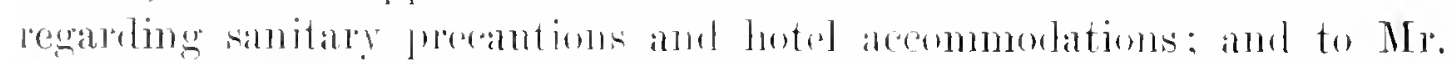
Campbell, of the burall of Transportation, for the excellent efupment

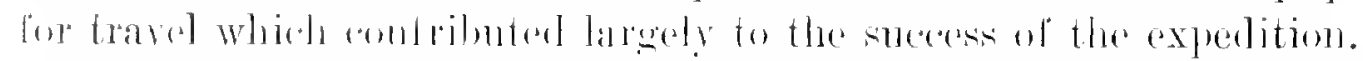

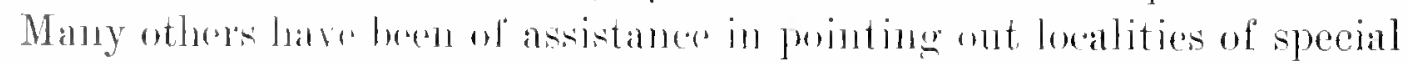
interest, in wiving names of leliable inliomants am in acpluanting us witle the usages and constoms of the enmotry. 


\section{BM:LIOGRAPlix}

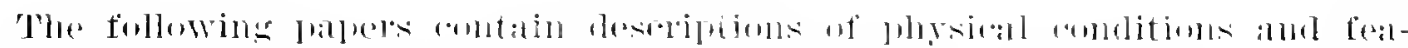

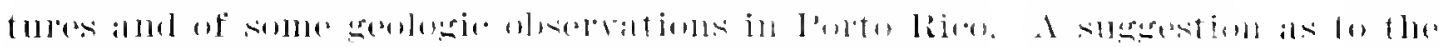

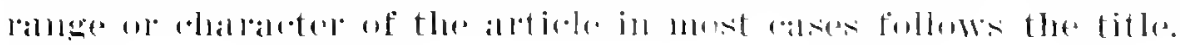

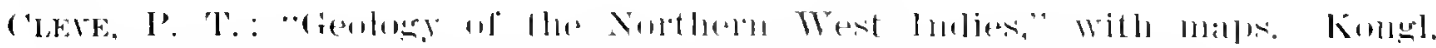

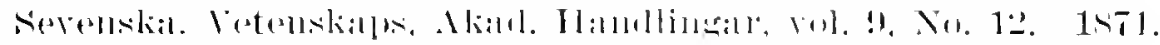

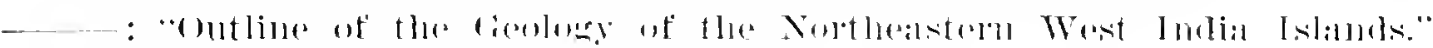

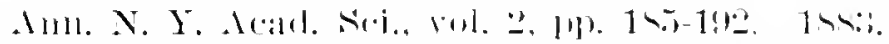

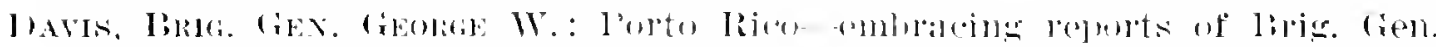

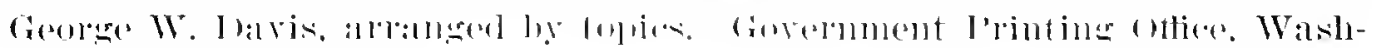

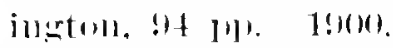

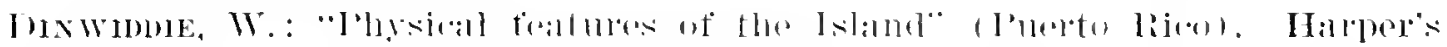

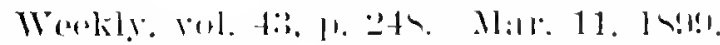

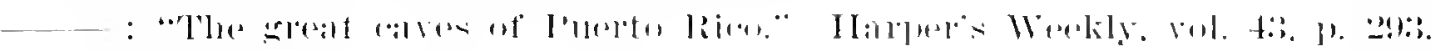

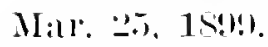

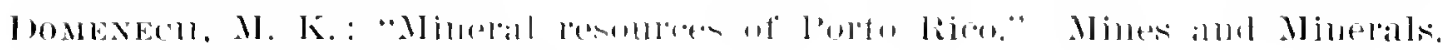

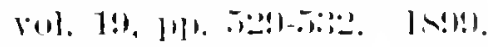

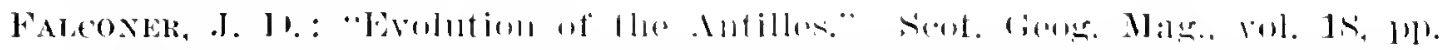

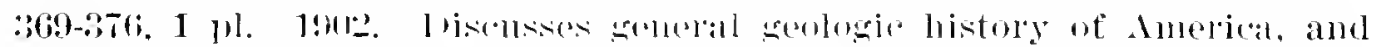

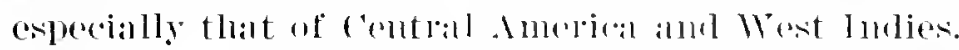

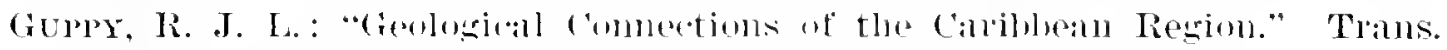

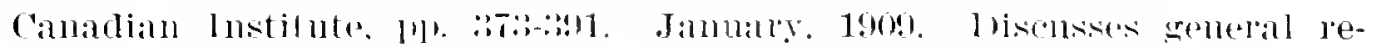

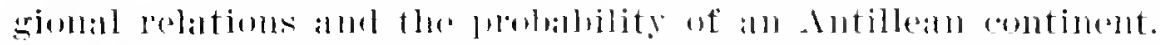

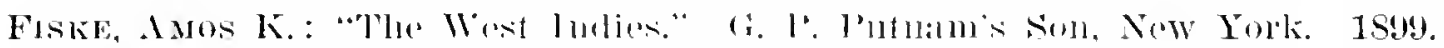

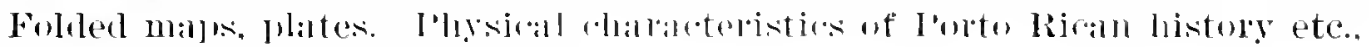

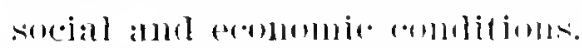

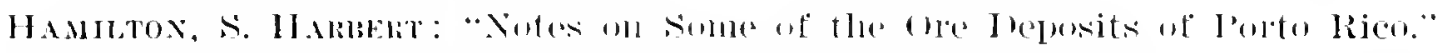

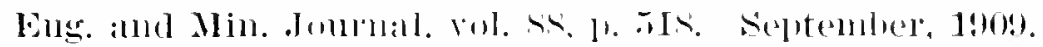

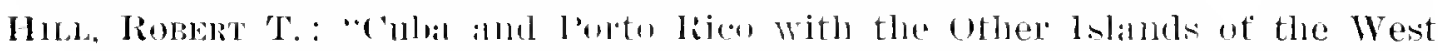
Indies." New York. 1sts. A lunk of orel too pages containing a rely latre amomut of information coverimer many matters in addition to the physical features allel the seoluger.

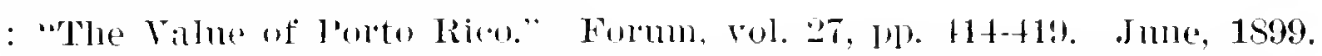

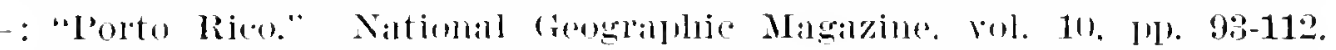

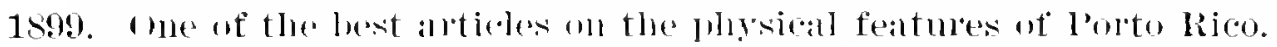

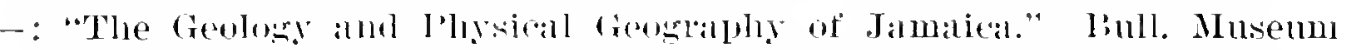
Comp. Kool., inl. :34. 1s!!!. I study of a type of Antillean development.

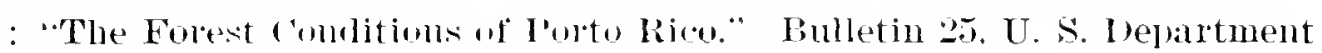

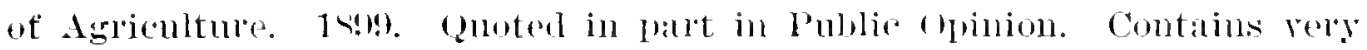
brief description of physicat features and has a good reliet map.

Newberry, J. S. : "Genlogy of the West Indies." Traus. N. Y. Acad. Sci., vol. 1, pp. 23-24. 185:.

Nitze, H. C. B.: "Investigations of Some of the Mineral Resources of Porto Rico." Twentieth Ann. Rept., U. s. Geological Survey, I'art 6, pp. 779-878. Gives a tabulation of the mineral orcurrences, and a very brief note on the principal ones. 


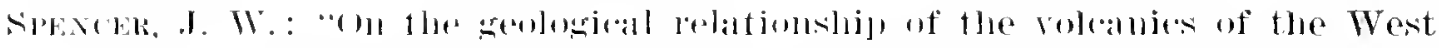

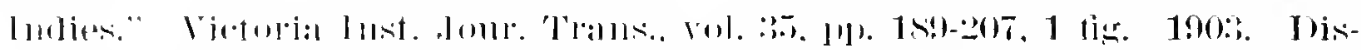

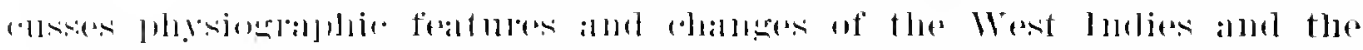

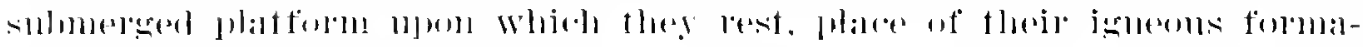

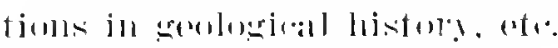

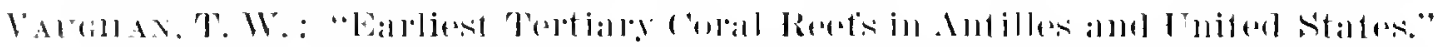

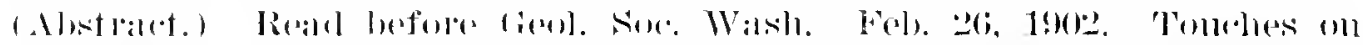

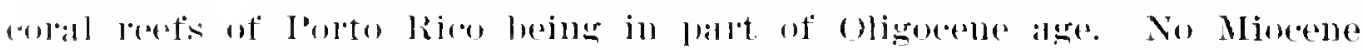

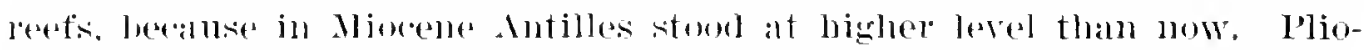

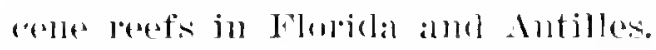

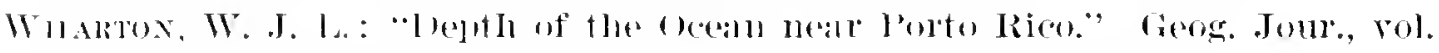

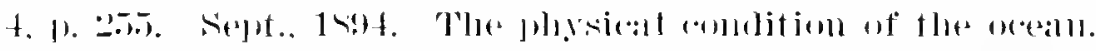

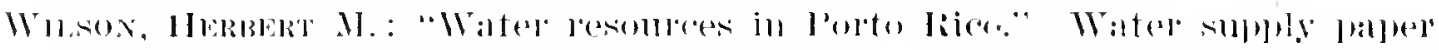

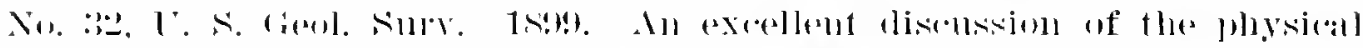

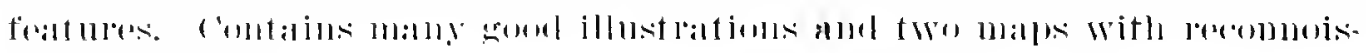
sall160 (-)

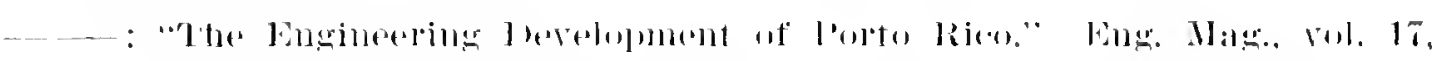

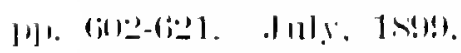

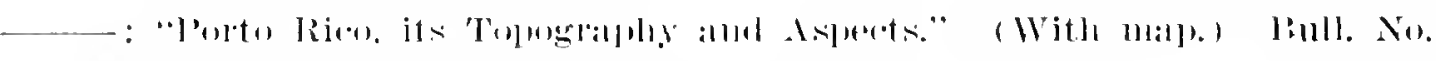

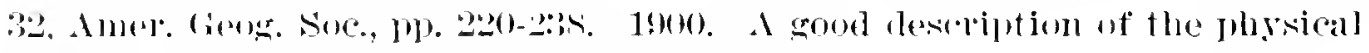

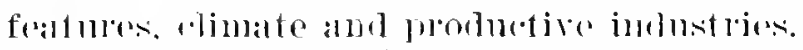

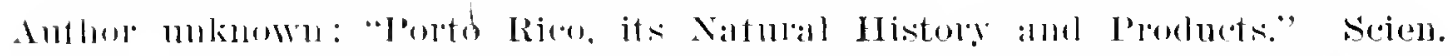
Am. Sulpul., rol. f6. July :;0, 1s:s. No author mentioned-good senelal

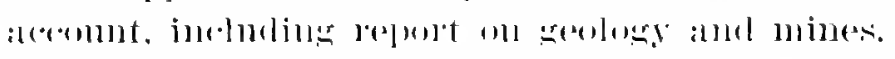

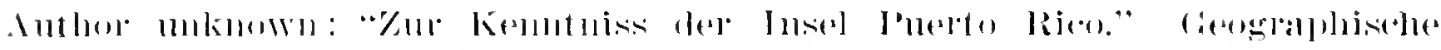

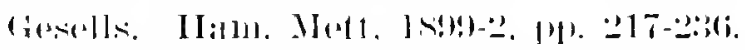

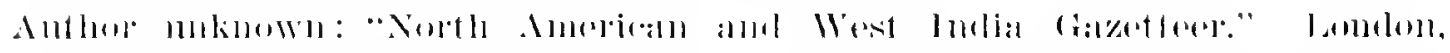

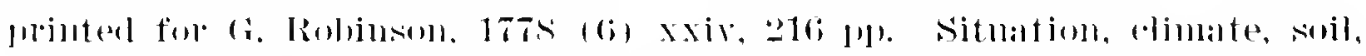

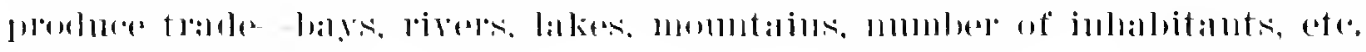
Mills. 光l exlitions. 


\section{CEOLOGICAL RECONINAISSANCE MAP}

\section{PORTO RICO}

\section{NEW YORK ACADEMYY OF SCIENCES EXPEDITION}

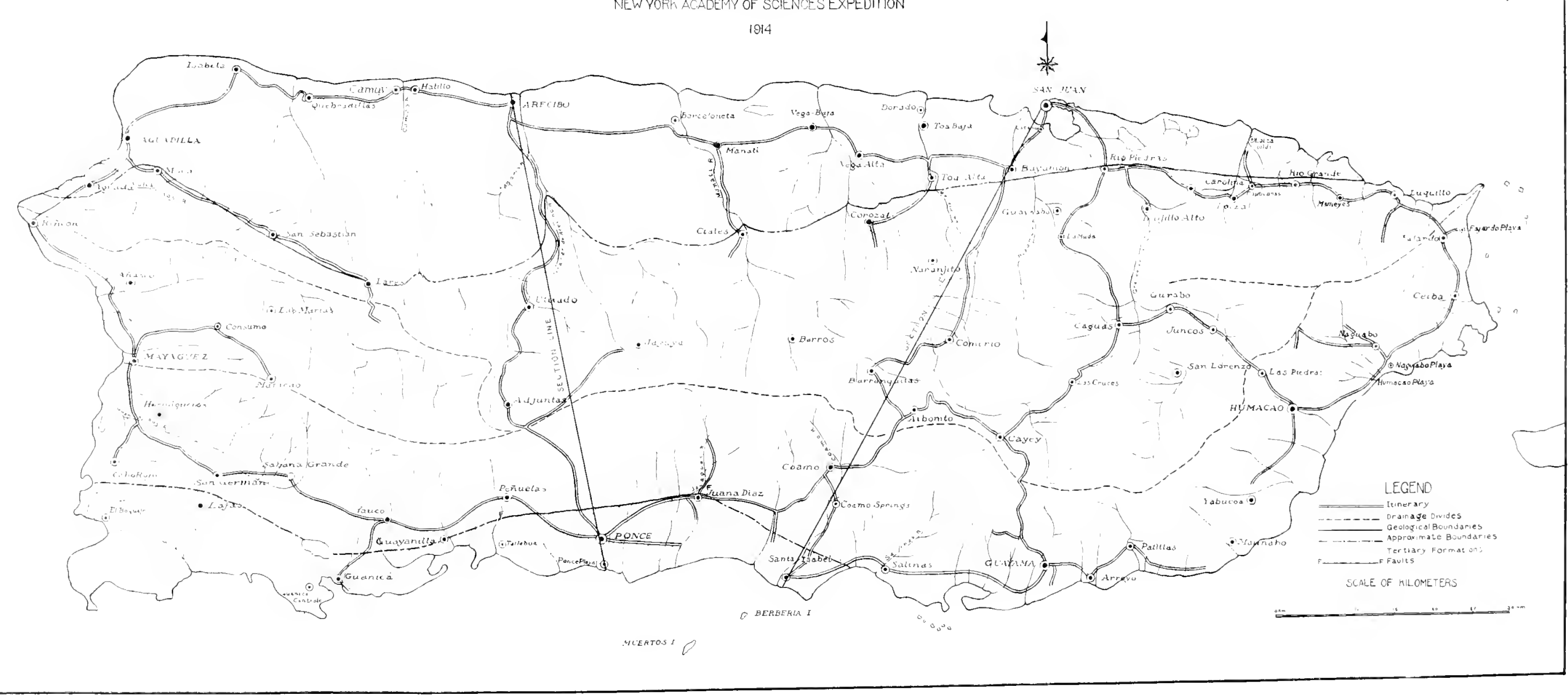






Science Q 11 . N5 26:1

Berkey, Charles P. 18671955.

Geulagical regonnalezance of Porto Rico 


\title{
PUBLICATIONS
}

11T TIIF

\section{NEW YORK ACADEMY OF SCIENCES}

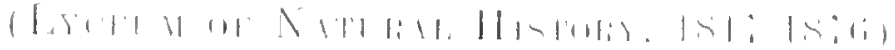

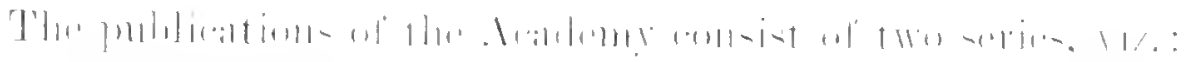

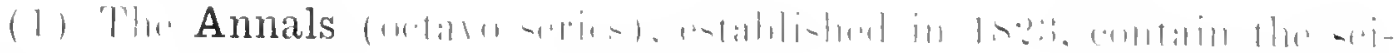

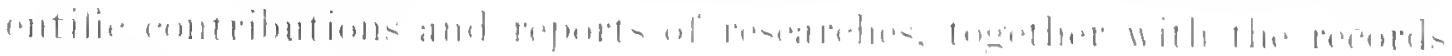

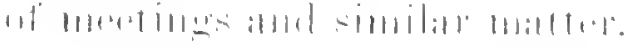

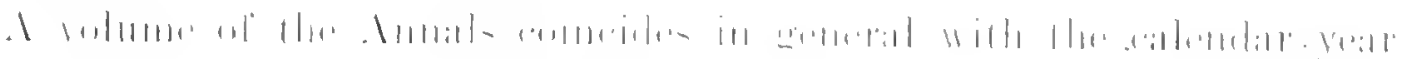

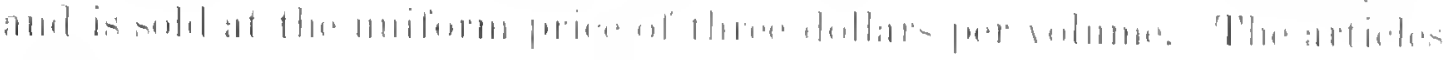

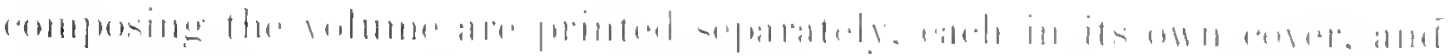

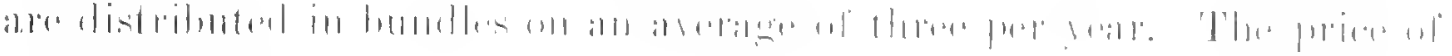

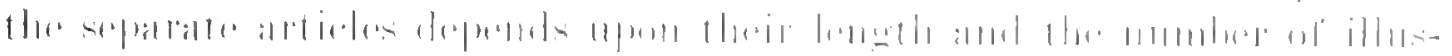

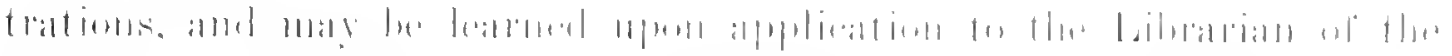

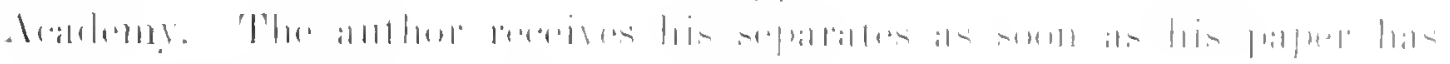

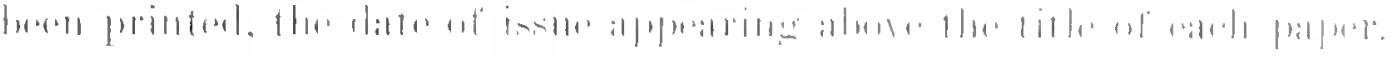

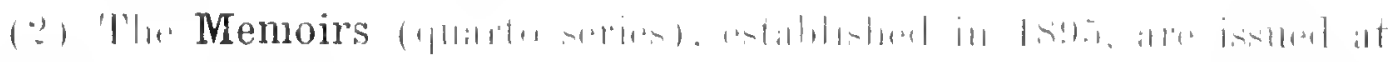

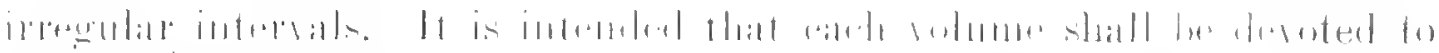

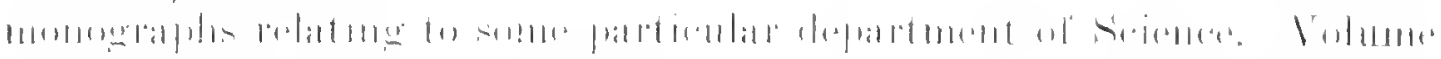

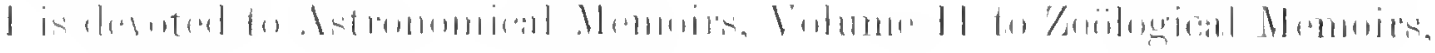

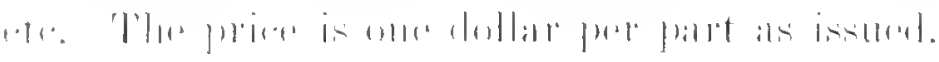

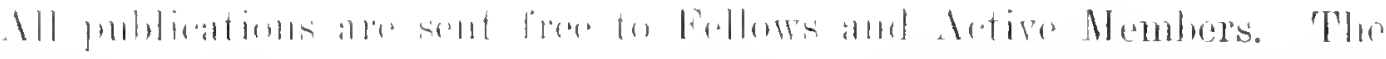

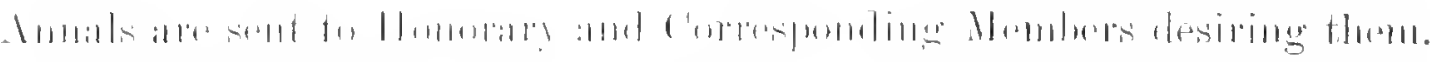

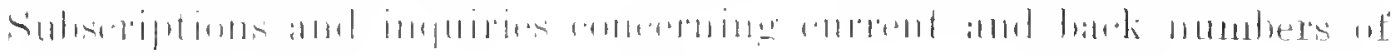

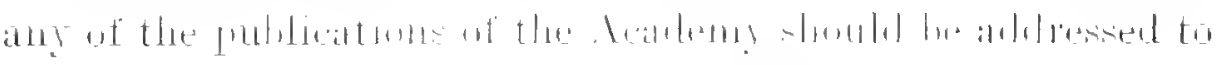

THE L.IHAHIU.

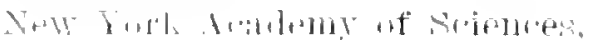

$1 \because 111,1,1$

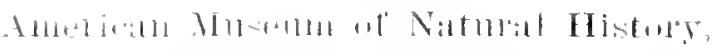

Nill L.M. N. I. 
